\title{
Data Base of Chemical Explosions in Kazakhstan
}

\author{
V.N. Demin
}

M.N. Malahova

P.N. Martysevich

N.N. Mihaylova

A. Nurmagambetov

Yu.F. Kopnichev

V.I. Edomin

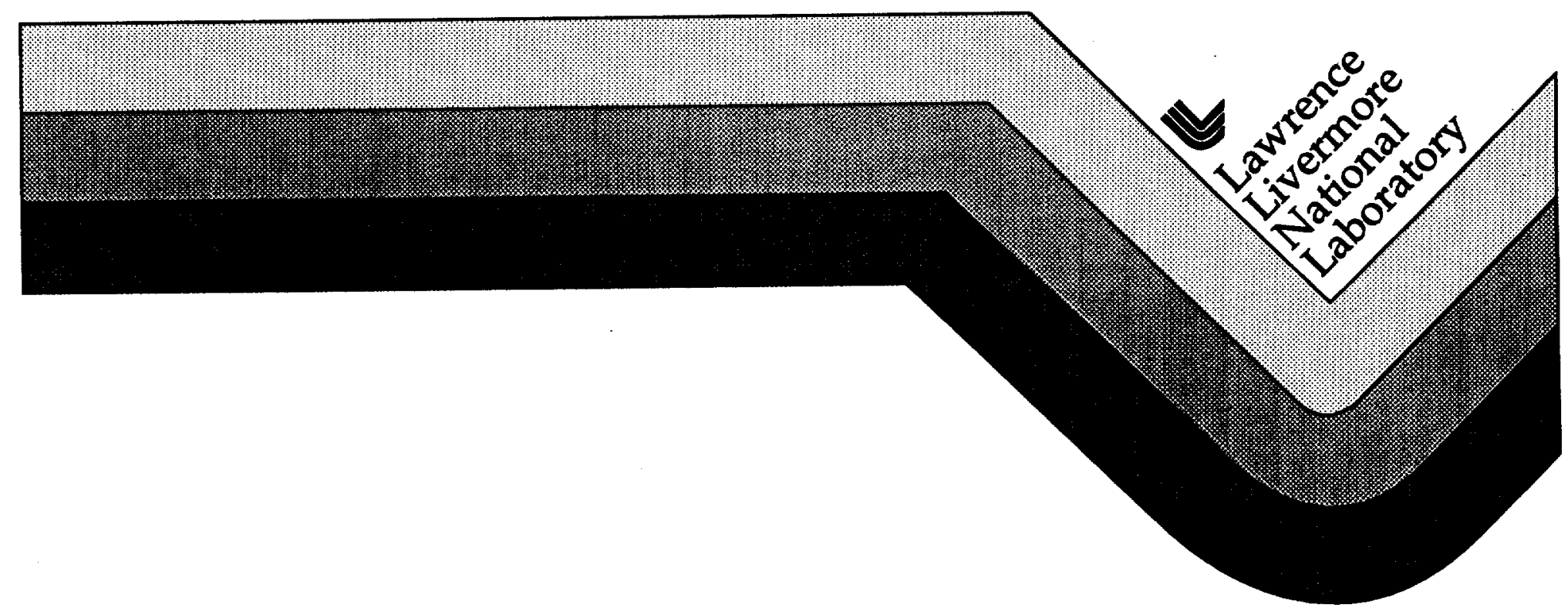




\section{DISCLADMER}

This document was prepared as an account of work sponsored by an agency of the United States Government. Neither the United States Government nor the University of Califomia nor any of their employees, makes any warranty, express or implied, or assumes any legal liability or responsibility for the accuracy, completeness, or usefulness of any information, apparatus, product, or process disclosed, or represents that its use would not infringe privately owned rights. Reference herein to any specific commercial product, process, or service by trade name, trademark, manufacturer, or otherwise, does not necessarily constitute or imply its endorsement, recommendation, or favoring by the United States Government or the University of California. The views and opinions of authors expressed herein do not necessarily state or reflect those of the United States Government or the University of California, and shall not be used for advertising or product endorsement purposes.

Work performed under the auspices of the U.S. Department of Energy by Lawrence Livermore National Laboratory under Contract W-7405-ENG-48. 


$$
\begin{array}{llr}
\text { National } & \text { Nuclear } & \text { Center } \\
\text { of Republic } & \text { of } & \text { Kazakhstan } \\
\text { Institute of Geophysical } & \text { Researches }
\end{array}
$$

\section{DATA BASE OF}

\section{CHEMICAI EXPLOSIONS}

\section{IN RAZAKHSTAN}

( report about a research works upon the Agreement N B301622 )

Kurchatov c. 


\section{The cast}

1. Demin V.N.

2. Malahova M.N.

3. Martysevich P.N.

4. Mihaylova N.N.

5. Nurmagambetov $A$.

6. Kopnichev Yu.F.

7. Edomin V.I.
Leader of theme

Engineer - Physicist

Engineer of the 1-st class

Leading scientist, c. of ph. $-\mathrm{m}$. $s$.

Leading scientist, d. of g.-m.s.

D. of g. - m. s., professor.

Junior research worker. 
CONTENTS

INTRODUCTION $\ldots \ldots \ldots \ldots \ldots \ldots \ldots \ldots \ldots \ldots . \ldots \ldots$

1. COMMON INEORMATION ABOUT QUARRY

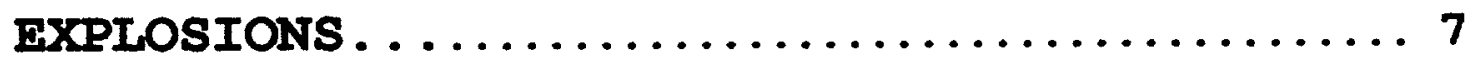

1.1 Quarries of Eastern Kazakhstan ......... 7

1.2 Quarries of Southern Kazakhstan ......... 16

1.3 Quarries of Northern Kazakhstan ......... 23

2. SHORT CHARACTERISTIC OF SEISMICITY OF

REGIONS OF IOCATION OF QUARRIES ........ 26

3. SYSTEM OE OBSERVATION AND APPARACY $\ldots \ldots \ldots 30$

4. IDENTIFICATION OF CHEMICAI EXPLOSIONS

ON THE SEISMIC RECORDS $\ldots \ldots \ldots \ldots \ldots \ldots \ldots$

4.1 Lists of explosions, exposed on the seismic records $\ldots \ldots \ldots \ldots \ldots \ldots \ldots \ldots$

4.1 .1 Southern Kazakhstan $\ldots \ldots \ldots \ldots \ldots \ldots \ldots \ldots \ldots$

4.1 .2 Eastern Kazakhstan $\ldots \ldots \ldots \ldots \ldots \ldots \ldots \ldots \ldots \ldots$

4.1 .3 Northern Kazakhstan $\ldots \ldots \ldots \ldots \ldots \ldots \ldots \ldots \ldots \ldots \ldots$

4.2 Correlations between the power class and summary weight of charge $\ldots \ldots \ldots \ldots \ldots \ldots \ldots \ldots$

4.3 Examples of records of explosions ..........54 
4.3.1 Southern Kazakhstan .................... 54

4.3.2 Eastern Kazakhstan ..................... 58

4.3.3 Northern Kazakhstan ..................... 59

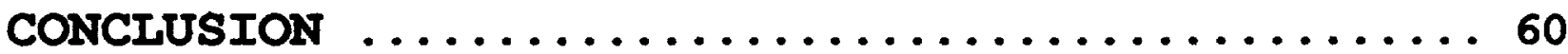

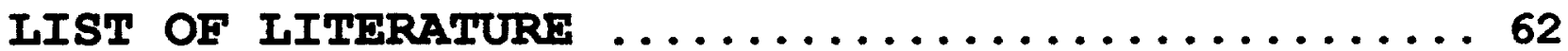

ILLUSTRATIONS TO THE TEXT $\ldots \ldots \ldots \ldots \ldots \ldots$ 


\section{INTRODUCTION}

Present report composed in accordance with Technical plan upon the theme " Data base on chemical explosions in Kazakstan " within the bounds of Agreement N B301622.

The total volume of present report is 131 pages. The report includes 4 chapters, 14 tables, 68 figures.

Within the bounds of report the following works were done :

1. Information about explosion quarries, located in Southern, Eastern and Nothern Kasakstan was summarized.

2. The general information about seismicity of areas of location of explosion quarries was adduced.

3. The system of observation and seismic apparatus, recording the local earthquakes and quarry explosions at the territory of Kazakstan were described.

4. Data base of quarry explosions, that were carried out in Southern, Eastern and Nothern Kazakstan during 1995 and first half of 1996 year was adduced.

5. Upon the data of registration of explosions in Southern Kazakstan the correlative dependances between power class of explosions and summary weight of charge were constructed.

6. Seismic records of quarry explosions were adduced.

It is necessary to note, that the collection of data about quarry explosions in Kazakstan in present time is very dificult task. Organisations, that makes these explosions, are always suffering reorganisations and sometimes it is actually impossible to receive all the necessary information. Some quarries are situated in remote, almost inaccessible regions, 
and within the bounds of supplyed financing not the every quarry was in succes to visit. So the present data base upon the chemical explosions for $1995 \mathrm{y}$. is not full and in further it's expansion is possible. 


\section{COMMON INEORMATION ABOUT QUARRY}

\section{EXPLOSIONS.}

At the territory of Southern, Eastern and Nothern Kazakstan annually is carry out the big number of chemical explosions for different economic needs ( quarry, road, building and another explosions 1. The biggest explosion - makers is Goverment joint-stock company "Jarilis" ( former Kazakh explosion industry ) and Goverment joint-stock " Ekibastuskomir " ( former group of enterprises of "Ekibastuscoal "). Below were described the explosion quarries, that belong to these two organisations, and also chemical explosions, that became known to us, that were carried out by different organisations and related with concrete building or another works.

\subsection{Quarries of Eastern Kazakhstan.}

In this paragraph described the quarries, that are situated on the territory of Eastern Kazakhstan and district of Semipalatinsk city, and they belong to the East-Kazakhstan territory administration of Goverment joint-stock company "Jarilis".

Quarry Novotaubinka is situated in $90 \mathrm{~km}$ by railway to south-east from semipalatinsk city, near railway station Suikbulak. At the quarry the works for extraction of limestone for cement factory of Semipalatinsk city are carried out. Strictly speaking, Novotaubinka - it is two quarries, old and new, situated in the distance of $2 \mathrm{~km}$ one from another. 
Configuration of explosions at the new and old quarries is different. Explosions are carried out in the holes, placed at the old quarry upon the quarter net with distance between holes 6 metres, and at the new - upon the rectangular net with distance between holes 2 metres in one direction and 2.5 metres in ortogonal. Coordinats of the old quarry $-49^{\circ} 47^{\prime} 40^{\prime \prime}$ of north latitude and $80^{\circ} 51^{\prime} 35^{\prime \prime}$ of east longitude. Co-ordinates of new quarry - $49^{\circ} 48^{\prime} 05^{\prime \prime}$ of north latitude and $80^{\circ} 52^{\prime} 50^{\prime \prime}$ of east longitude. During the period under review at the old quarry were carried out 25 explosions of difficult configuration - with great quantity of detonators and time stretching. All the information about these explosions was represented to us by organisation, making these explosions and was adduced in table 1 .

Table 1. Data about chemical explosions, that were carried out during 1995 year and during first half of 1996 year at the old quarry of Novotaubinka.

\begin{tabular}{|c|c|c|c|c|c|}
\hline Date & $\begin{array}{c}\text { Total } \\
\text { weight of } \\
\text { charge,kg }\end{array}$ & $\begin{array}{c}\text { Amount of } \\
\text { holes }\end{array}$ & $\begin{array}{c}\text { Depth of } \\
\text { holes, } \mathrm{m}\end{array}$ & $\begin{array}{c}\text { Amount of } \\
\text { detona- } \\
\text { tors }\end{array}$ & $\begin{array}{c}\text { Volume of } \\
\text { explosed } \\
\text { rock, } \mathrm{m}^{3}\end{array}$ \\
\hline 26.01 .95 & 16656 & 68 & 14.4 & 12 & \\
\hline
\end{tabular}




\begin{tabular}{|c|c|c|c|c|c|}
\hline Date & $\begin{array}{c}\text { Total } \\
\text { weight of } \\
\text { charge,kg }\end{array}$ & $\begin{array}{c}\text { Amount of } \\
\text { holes }\end{array}$ & $\begin{array}{l}\text { Depth of } \\
\text { holes, } m\end{array}$ & $\begin{array}{c}\text { Amount of } \\
\text { detona- } \\
\text { tors }\end{array}$ & $\begin{array}{l}\text { Volume of } \\
\text { explosed } \\
\text { rock, } \mathrm{m}^{3}\end{array}$ \\
\hline 26.02 .95 & 8160 & 34 & 14.4 & 10 & \\
\hline 28.02 .95 & 1831 & 31 & 12 & 8 & \\
\hline 24.03 .95 & 3984 & 27 & 10 & 8 & 15000 \\
\hline 28.03 .95 & 3424 & & & 10 & 6000 \\
\hline 19.04 .95 & 7942 & 38 & 12 & 10 & \\
\hline 20.04 .95 & 5608 & 31 & 10.5 & 12 & \\
\hline 25.05 .95 & 3138 & 55 & 10 & 2 & \\
\hline 05.06 .95 & 6929 & 33 & 12 & 10 & \\
\hline 23.06 .95 & 4301 & 17 & 12.5 & 4 & 5000 \\
\hline 17.07 .95 & 6172 & 80 & 10.8 & 12 & \\
\hline 14.08 .95 & 2970 & 66 & 10.8 & 14 & 2700 \\
\hline 26.08 .95 & 1068 & 22 & 10.8 & 6 & \\
\hline
\end{tabular}




\begin{tabular}{|c|c|c|c|c|c|}
\hline Date & $\begin{array}{c}\text { Total } \\
\text { weight of } \\
\text { charge,kg }\end{array}$ & $\begin{array}{c}\text { Amount of } \\
\text { holes }\end{array}$ & $\begin{array}{l}\text { Depth of } \\
\text { holes, } m\end{array}$ & $\begin{array}{l}\text { Amount of } \\
\text { detona- } \\
\text { tors }\end{array}$ & $\begin{array}{l}\text { Volume of } \\
\text { explosed } \\
\text { rock, } \mathrm{m}^{3}\end{array}$ \\
\hline 27.09 .95 & 2526 & 13 & 12 & 4 & \\
\hline 05.10 .95 & 1278 & 6 & 12 & 6 & \\
\hline 12.10 .95 & 2707 & 13 & 12 & 2 & \\
\hline 18.10 .95 & 7113 & 30 & 12 & 7 & 9000 \\
\hline 24.10 .95 & 5894 & 30 & 12 & 10 & \\
\hline 06.11 .95 & 5442 & 16 & 12 & 5 & \\
\hline 23.11 .95 & 2954 & 15 & 13.2 & 6 & \\
\hline 19.12 .95 & 7538 & 38 & 12 & 14 & \\
\hline 28.12 .95 & 7157 & 34 & 13.2 & 16 & \\
\hline 24.01 .96 & 11790 & 57 & 12.5 & 18 & 23870 \\
\hline 13.03 .96 & 14735 & & & 32 & 12675 \\
\hline
\end{tabular}




\begin{tabular}{|c|c|c|c|c|c|}
\hline Date & Total & Amount of & Depth of & Amount of & Volume of \\
& weight of & holes & holes, $m$ & detona- \\
charge,kg & & & $\begin{array}{c}\text { explosed } \\
\text { tors }\end{array}$ & rock, $\mathrm{m}^{3}$ \\
\hline 05.05 .96 & 9644 & & & 10 & \\
\hline
\end{tabular}

In the same time at the new quarry were carried out 17 explosions, information about which was adduted in table 2 .

Table 2. Data about chemical explosions, that were carried out during 1995 year and during first half of 1996 year at the new quarry of Novotaubinka.

\begin{tabular}{|c|c|c|c|c|c|}
\hline Date & $\begin{array}{c}\text { Total } \\
\text { weight of } \\
\text { charge,kg }\end{array}$ & $\begin{array}{c}\text { Amount of } \\
\text { holes }\end{array}$ & $\begin{array}{c}\text { Depth of } \\
\text { holes, } \mathrm{m}\end{array}$ & $\begin{array}{c}\text { Amount of } \\
\text { detona- } \\
\text { tors }\end{array}$ & $\begin{array}{c}\text { Volume of } \\
\text { explosed } \\
\text { rock, } \mathrm{m}^{3}\end{array}$ \\
\hline 26.01 .95 & 4636 & 198 & 6.4 & 12 & \\
\hline 16.02 .95 & 3751 & 22 & 10.5 & 6 & \\
\hline 22.02 .95 & 986 & 44 & 7.2 & 10 & \\
\hline
\end{tabular}




\begin{tabular}{|c|c|c|c|c|c|}
\hline Date & $\begin{array}{c}\text { Total } \\
\text { weight of } \\
\text { charge,kg }\end{array}$ & $\begin{array}{c}\text { Amount of } \\
\text { holes }\end{array}$ & $\begin{array}{l}\text { Depth of } \\
\text { holes, } m\end{array}$ & $\begin{array}{c}\text { Amount of } \\
\text { detona- } \\
\text { tors }\end{array}$ & $\begin{array}{l}\text { Volume of } \\
\text { explosed } \\
\text { rock, } \mathrm{m}^{3}\end{array}$ \\
\hline 26.02 .95 & 4320 & 180 & 5.5 & 10 & \\
\hline 23.03 .95 & 5452 & 230 & from 2.5 to 8 & 12 & 8700 \\
\hline 20.06 .95 & 4159 & 85 & 10.8 & 10 & \\
\hline 10.07 .95 & 1910 & 39 & 10.8 & 10 & \\
\hline 06.09 .95 & 1914 & 9 & 10 & 6 & \\
\hline 10.09 .95 & 1080 & 34 & 10.8 & 6 & \\
\hline 16.09 .95 & 3232 & 34 & 12 & 12 & \\
\hline 12.10 .95 & 2570 & 40 & 12 & 4 & \\
\hline 06.11 .95 & 957 & 14 & 12 & 5 & \\
\hline 24.11 .95 & 7626 & 132 & $\begin{array}{c}\text { from } 9.6 \text { to } \\
10.8\end{array}$ & 12 & \\
\hline 18.12 .95 & 11986 & 200 & 11.5 & 20 & 21840 \\
\hline
\end{tabular}




\begin{tabular}{|c|c|c|c|c|c|}
\hline Date & $\begin{array}{c}\text { Total } \\
\text { weight of } \\
\text { charge,kg }\end{array}$ & $\begin{array}{c}\text { Amount of } \\
\text { holes }\end{array}$ & $\begin{array}{c}\text { Depth of } \\
\text { holes, } m\end{array}$ & $\begin{array}{c}\text { Amount of } \\
\text { detona- } \\
\text { tors }\end{array}$ & $\begin{array}{c}\text { Volume of } \\
\text { explosed } \\
\text { rock, } \mathrm{m}^{3}\end{array}$ \\
\hline 26.01 .96 & 7670 & 92 & 11.5 & 12 & 15840 \\
\hline 06.03 .96 & 9376 & 104 & 12 & 10 & 31525 \\
\hline 20.06 .96 & 10692 & 116 & 12 & 14 & \\
\hline
\end{tabular}

Quarry Sajaevka is situated in $120 \mathrm{~km}$ by railway to south-east from Ust-Kamenogorsk city, on the shore of Buhtarma reservoire. At the quarry the works for extracting of limestone for Ust-Kamenogorsk cement factory are carried out. Co-ordinates of quarry - $49^{\circ} 36^{\prime} 20^{\prime \prime}$ of north latitude and $83^{\circ} 39^{\prime} 00^{\prime \prime}$ of east longitude. During the period under review at the quarry were carried out 11 explosions by the same scheme, how at the old quarry of Novotaubinka, that is in the holes, located quarter net $6 \times 6 \mathrm{~m}$. Information about these explosions, that was given to us by organisation-maker of these works, is shown in table 3 .

Table 3. Data about chemical explosions, that were carried out in 1995 and first half of 1996 year at the quarry of Sajaevka. 


\begin{tabular}{|c|c|c|c|c|c|}
\hline Date & $\begin{array}{c}\text { Total } \\
\text { weight of } \\
\text { charge,kg }\end{array}$ & $\begin{array}{c}\text { Amount of } \\
\text { holes }\end{array}$ & $\begin{array}{l}\text { Depth of } \\
\text { holes, } m\end{array}$ & $\begin{array}{c}\text { Amount of } \\
\text { detona- } \\
\text { tors }\end{array}$ & $\begin{array}{l}\text { Volume of } \\
\text { explosed } \\
\text { rock, } \mathrm{m}^{3}\end{array}$ \\
\hline 25.01 .95 & 29194 & 100 & $\overline{13.2}$ & 20 & 27525 \\
\hline 30.03 .95 & 40883 & 140 & 15 & 28 & 30000 \\
\hline 20.06 .95 & 21318 & 146 & $\begin{array}{c}\text { from } 13.5 \text { to } \\
14.4\end{array}$ & 10 & 21017 \\
\hline 28.07 .95 & 19600 & 70 & 14 & 14 & \\
\hline 24.08 .95 & 14750 & 59 & 12 & 14 & 39000 \\
\hline 18.09 .95 & 16552 & 57 & 12 & 18 & 15000 \\
\hline 20.09 .95 & 18904 & 94 & 10.8 & 8 & 25000 \\
\hline 01.11 .95 & 44968 & 146 & 14.5 & 38 & 30000 \\
\hline 21.12 .95 & 18668 & 75 & 10 & 18 & 30000 \\
\hline 11.04 .96 & 31248 & 124 & 12 & 28 & 25000 \\
\hline 23.05 .96 & 15048 & 85 & 12 & 18 & 34000 \\
\hline
\end{tabular}


Quarry Alakol is situated at the prolongation of south-eastern prominance of Alakol lake ( Kishi-Alakol bay), near Uzunbulak settlement. At this quarry the works for extracting of coal are carried out. Co-ordinates of this quarry - $45^{\circ} 43^{\prime} 50^{\prime \prime}$ of north latitude and $82^{\circ} 10^{\prime} 00^{\prime \prime}$ of east longitude. Explosions are carried out in holes, placed upon the rectangular net $2.5 \times 3 \mathrm{~m}$. 4 explosions were carried out, information about which was given in table 4 .

Table 4. Data about chemical explosions, that were carried out in 1995 and first half of 1996 year at the quarry Alakol.

\begin{tabular}{|c|c|c|c|c|c|}
\hline Date & $\begin{array}{c}\text { Total } \\
\text { weight of } \\
\text { charge,kg }\end{array}$ & $\begin{array}{c}\text { Amount of } \\
\text { holes }\end{array}$ & $\begin{array}{l}\text { Depth of } \\
\text { holes, } m\end{array}$ & $\begin{array}{c}\text { Amount of } \\
\text { detona- } \\
\text { tors }\end{array}$ & $\begin{array}{l}\text { Volume of } \\
\text { explosed } \\
\text { rock, } \mathrm{m}^{3}\end{array}$ \\
\hline 13.01 .95 & 7010 & 200 & 10 & 15 & \\
\hline 26.01 .95 & 13960 & 400 & 9.5 & 20 & \\
\hline 20.02 .95 & 13198 & 300 & 10 & 10 & 60000 \\
\hline 21.05 .95 & 14580 & 175 & 13 & 27 & 60000 \\
\hline
\end{tabular}


The explosion works were carried out at the road bridge of Shemonaiha city at 28 of March 1995 year, with aim to crush the ice. 30 charges (total power $=1960 \mathrm{~kg}$ ) of demolition explosives were exploded. Co-ordinates of road bridge of Shemonaiha - $50^{\circ} 37^{\prime} 05^{\prime \prime}$ of north latitude and $81^{\circ} 55^{\prime} 00^{\prime \prime}$ of east longitude.

All given above information about explosions had been received by us in East-Kazakhstan territory administration of Goverment joint-stock company " Jarilis " in Ust-Kamenogorsk city. Unfortunatly, workmakers couldn't give us exact time of making every explosion ( that would be very usefull for assured identification of explosions at the seismic records ), and informed us only, that in the daily work routine explosions are carried out, as a rule, in interval between 16 and 17 hours of local time.

\subsection{Quarries of Southern Kazakhstan.}

The quarries, that are situated at the territory of Almaty and Taldykurgan regions, are described in this paragraph.

Quarry Kotur-Bulak is situated in direct closeness to Almaty city. Explosions are carried out here till 1965 year. In last time the frequence of explosions in this quarry consisted examplarily $10-12$ explosions in year. The weight of charge of ingle explosion consisted $10000-12000 \mathrm{~kg}$. Porphirites of nine group were disclosed by explosions in accordance with building norms and rules (BNaR). In last years at this quarry are carried 
not more 3-4 explosions in year with average power $7000 \mathrm{~kg}$. Quarry of zholaman plant of rock debris is situated westwards from Sary-ozek settlement in Malaysary mountains and working from 1966 year. Earlier here 10-12 explosions with summary weight $10000-12000 \mathrm{~kg}$ were carried out. At present time the amount of explosions abruptly decrease and consist 4 explosions in year examplarily for $10000 \mathrm{~kg}$ every. Porphirites of $\mathrm{X}$ group are extracted in accordance with BNaR.

Quarry of Chilbastau plant of road building materials is situated to the north-east from otar settlement. It is used from 1972 year, limestones of VIII group are disclosed by quarry explosions in accordance with BNaR. Amount of explosions decrease from 10-12 in year (10000-20000 kg everyone) to 1-3 in year (10000 kg).

In $15 \mathrm{~km}$ to the north from Kapchagay city the quarry N $12 \mathrm{a}$ of Kapchagay plant of building materials is situated. Explosions are carried out here from 1965 year. Earlear 12 explosions in year with weight equal to $5000 \mathrm{~kg}$ were carried out here. In last years amount of them decreased to $4-5$ in year. Porphyrites of $x$ group are extracted here in accordance with BNaR.

There is Kusak quarry of Karabulak sugar plant in Taldy-Kurgan region. 4 explosions for 5000-7000 kg every are carried out here in one year.

The explosions connected with mining are produced on the mine near Tekely city. These are West, Tekely and Koksu quarries.

There are places, where explosions re carried out during the limit period of time, and they are connected with building or another works. There are single explosions also 
are maked by different organizations.

In accordance with data that we received, over whelming majority of explosions were produced over observing territory are the single.

The table 5 show the co-ordinates of well-known explosion quarries in Almaty and Taldy-Kurgan regions and adjacent areas of Kazakhstan Republic. The map of quarrie's desposition within the limits of this territory is shown on fig. 1.

Table 5. The coordinates of regions of carrying out of explosions on the territory of southern Kazakhstan.

\begin{tabular}{|c|c|c|c|}
\hline $\mathbf{N}$ & Name of site & North latitude & East longitude \\
\hline 1 & (quarry) & $43^{\circ} 15^{\prime}$ & $77^{\circ} 06^{\prime}$ \\
\hline 2 & Kotur-Bulak & & \\
\hline 3 & Jolaman & $44^{\circ} 15^{\prime}$ & $77^{\circ} 35^{\prime}$ \\
& Chilbastau & & \\
\hline 4 & & $43^{\circ} 42^{\prime}$ & $75^{\circ} 20^{\prime}$ \\
& & & $77^{\circ} 01^{\prime}$ \\
\hline 5 & Quarry 12a & $43^{\circ} 58^{\prime}$ & \\
\hline
\end{tabular}




\begin{tabular}{|c|c|c|}
\hline $\mathbf{N}$ & North latitude & East longitude \\
\hline 6 & $44^{\circ} 40^{\prime}$ & $78^{\circ} 58^{\prime}$ \\
\hline 7 & $44^{\circ} 48^{\prime}$ & $78^{\circ} 54^{\prime}$ \\
\hline 8 & $44^{\circ} 50^{\prime}$ & $78^{\circ} 53^{\prime}$ \\
\hline 9 & $45^{\circ} 01^{\prime}$ & $78^{\circ} 12^{\prime}$ \\
\hline 10 & $44^{\circ} 02^{\prime}$ & $77^{\circ} 27^{\prime}$ \\
\hline 11 & $43^{\circ} 38^{\prime}$ & $75^{\circ} 47^{\prime}$ \\
\hline 12 & $43^{\circ} 50^{\prime}$ & $74^{\circ} 44^{\prime}$ \\
\hline 13 & $42^{\circ} 53^{\prime}$ & $76^{\circ} 05^{x}$ \\
\hline 14 & $43^{\circ} 05^{\prime}$ & $74^{\circ} 53^{\prime}$ \\
\hline
\end{tabular}

To receive the detailed information about produced explosions from direct makers of explosions not possible in any 
time. Organisations-makers are situated in different towns of Republic, and often they stay unknown for seismologists. All, that w could know about quarry and other explosions, that were carried out in 1995 year at the territory of Almaty and Taldy-Kurgan regions is shown in table 6.

Table 6. Data about chemical explosions, that were carried out in 1995 year at the territory of Almaty and Taldy-Kurgan regions.

\begin{tabular}{|c|c|c|c|}
\hline Date & $\begin{array}{c}\text { Name of the site of } \\
\text { explosion }\end{array}$ & Producer & $\begin{array}{l}\text { Total weight of } \\
\text { charge, } \mathrm{kg}\end{array}$ \\
\hline 24.01 .95 & $\begin{array}{c}\text { Jolaman, the hole } \\
\varnothing 250 \mathrm{~mm}\end{array}$ & GJ-SC «Jarilis» & 5750 \\
\hline 07.02 .95 & $\begin{array}{c}\text { Kotur-Bulak, the hole } \\
\varnothing 105 \mathrm{~mm}\end{array}$ & GJ-SC «Jarilis» & 5204 \\
\hline 21.02 .95 & Lowering of snow-slip & & 80 \\
\hline 28.02 .95 & $\begin{array}{c}\text { Quarry } 12 \mathrm{a} \text {, the hole } \\
\varnothing 125 \mathrm{~mm}\end{array}$ & & 1135 \\
\hline 11.03 .95 & $\begin{array}{l}\text { Jolaman, the holes } \\
\varnothing 218 \text { and } \varnothing 270 \mathrm{~mm}\end{array}$ & GJ-SC *Jarilis» & 14157 \\
\hline 21.03 .95 & $\begin{array}{c}\text { Kalpatasskyi, the hole } \\
\varnothing 105 \mathrm{~mm}\end{array}$ & & 30 \\
\hline
\end{tabular}




\begin{tabular}{|c|c|c|c|}
\hline Date & $\begin{array}{c}\text { Name of the site of } \\
\text { explosion }\end{array}$ & Producer & $\begin{array}{c}\text { Total weight of } \\
\text { charge, } \mathrm{kg}\end{array}$ \\
\hline 28.03 .95 & Lowering of snow-slip & & 100 \\
\hline 03.04 .95 & Lowering of snow-slip & & 100 \\
\hline 07.04 .95 & & & 1749 \\
\hline 08.04 .95 & & & 392 \\
\hline 27.04 .95 & $\begin{array}{l}\text { Kusakskyi, the hole } \\
\qquad \varnothing 105 \mathrm{~mm}\end{array}$ & GJ-SC \&Jarilis» & 7033 \\
\hline 16.05 .95 & $\begin{array}{l}\text { Quarry } 12 \mathrm{a}, \text { the hole } \\
\qquad 125 \mathrm{~mm}\end{array}$ & & 1241 \\
\hline 17.05 .95 & $\begin{array}{l}\text { Jolaman, the hole } \\
\qquad \varnothing 269 \mathrm{~mm}\end{array}$ & GJ-SC *Jarilis» & 12622 \\
\hline 01.06 .95 & $\begin{array}{c}\text { Quarry } 12 a \text {, the hole } \\
\varnothing 125 \mathrm{~mm}\end{array}$ & & 140 \\
\hline 07.07 .95 & $\begin{array}{c}\text { Ushalyk, the hole } \\
\varnothing 105 \mathrm{~mm}\end{array}$ & & 5000 \\
\hline 10.07 .95 & $\begin{array}{c}\text { Adek-Su, the hole } \\
\varnothing 250 \mathrm{~mm}\end{array}$ & & 2781 \\
\hline 11.07 .95 & $\begin{array}{c}\text { Quarry } 12 a, \text { the hole } \\
\varnothing 125 \mathrm{~mm}\end{array}$ & & 596 \\
\hline 14.07 .95 & Jolaman, the hole & GJ-SC «Jarilis» & 11050 \\
\hline
\end{tabular}




\begin{tabular}{|c|c|c|c|}
\hline & $\varnothing 269 \mathrm{~mm}$ & & \\
\hline 03.08 .95 & Dalabay & & 5000 \\
\hline 18.08 .95 & $\begin{array}{c}\text { Quarry 12a, the hole } \\
\varnothing 125 \mathrm{~mm}\end{array}$ & & 732 \\
\hline 25.08 .95 & $\begin{array}{c}\text { Broadening of the road in } \\
\text { Turgen gorge } \\
\text { (explosions in the bore-holes } \\
\qquad \varnothing 42 \mathrm{~mm} \text { ) }\end{array}$ & & 360 \\
\hline 30.08 .95 & $\begin{array}{c}\text { Kusakskyi, the hole } \\
\varnothing 105 \mathrm{~mm}\end{array}$ & & 6776 \\
\hline 06.09 .95 & $\begin{array}{c}\text { Jolaman, the hole } \\
\varnothing 250 \mathrm{~mm}\end{array}$ & GJ-SC \& Jarilis» & 12087.5 \\
\hline 10.10 .95 & Burabayjal station & Deposite of barytes & 965 \\
\hline 04.11 .95 & Quarry Kusakskyi & $\begin{array}{c}\text { Karabulak sugar } \\
\text { plant }\end{array}$ & 8190 \\
\hline 24.11 .95 & $\begin{array}{c}\text { Jolaman, the hole } \\
\varnothing 250 \mathrm{~mm}\end{array}$ & GJ-SC \&Jarilis» & 12881 \\
\hline 17.12 .95 & Quarry Kusakskyi & $\begin{array}{c}\text { Karabulak sugar } \\
\text { plant }\end{array}$ & 6435 \\
\hline
\end{tabular}




\subsection{Quarries of Northern Kazakhstan.}

In environ of Ekibastuz city 5 coal quarries are situated, and on each of them actually everyday a several number of chemical explosions is carried out. Four quarries - Northern, Eastern, Stepnoy and Bogatyr - directly join to the city from the ast and south-east, and have a sharp of arcs with length $\operatorname{till} 10 \mathrm{~km}$.

Fifths quarry - Maykubenskyi - is situated in $60 \mathrm{~km}$ to the south from the city. On the fig.2 schematic image of location of four suburb quarries concerning each other and elements of country were given. Total number of explosions, that are carried out at the all of quarries - from 10 to 20 in day. During one and half year the total amount of explosions can reach a number of 10 thousand. If we had adduced here such a volume of information, the size of present reports would have gone out of required limits.

Table 7 gives the data about explosions for 1 day - 19 Dec,1995 for example. If the customer have an interest to chemical explosions in Nortern Kazakhstan for concrete segment of time we can to represent all necessary data.

Explosion works at all quarries are carried out in the boreholes by the method of short-slow explosion - for several steps with the interval between step equal to 35 - $50 \mathrm{~ms}$. Table

Table 7. Data about chemical explosions, that are carried out at the coal quarries of" Ekibastuzkomir " on 19 Dec, 1995. 


\begin{tabular}{|c|c|c|c|c|}
\hline Name of quarry & $\begin{array}{c}\text { Depth of } \\
\text { hole }\end{array}$ & $\begin{array}{c}\text { Amount of } \\
\text { stages of } \\
\text { delay }\end{array}$ & $\begin{array}{l}\text { Maximum } \\
\text { weight of } \\
\text { charge for } \\
\text { one stage, } \\
\text { kg }\end{array}$ & $\begin{array}{l}\text { Total weight } \\
\text { of charge, } \mathrm{kg}\end{array}$ \\
\hline Bogatyr & 18 & 8 & 684 & 4788 \\
\hline Bogatyr & 24 & 12 & 882 & 10584 \\
\hline Bogatyr & 26 & 3 & 710 & 2130 \\
\hline Bogatyr & 26 & 3 & 936 & 2808 \\
\hline Severnyi & 21 & 10 & 387 & 3870 \\
\hline Severnyi & 14 & 5 & 158 & 788 \\
\hline Severnyi & 8 & 6 & 119 & 712 \\
\hline Severnyi & 10 & 6 & 218 & 1290 \\
\hline Stepnoy & $\begin{array}{c}0 \\
\text { (laid on } \\
\text { charges) }\end{array}$ & 7 & 180 & 1260 \\
\hline
\end{tabular}




\begin{tabular}{|c|c|c|c|c|}
\hline Name of quarry & $\begin{array}{c}\text { Depth of } \\
\text { hole }\end{array}$ & $\begin{array}{r}\text { Amount of } \\
\text { stages of } \\
\text { delay }\end{array}$ & $\begin{array}{r}\text { Maximum } \\
\text { weight of } \\
\text { charge for } \\
\text { one stage, }\end{array}$ & of charge, $\mathrm{kg}$ \\
\hline Stepnoy & 18 & 26 & 258 & 6708 \\
& & & & \\
\hline Stepnoy & $10-18$ & 35 & 287 & 10032 \\
\hline Maykubenskyi & 12 & 5 & 510 & 2547 \\
\hline
\end{tabular}

At the Eastern quarry in this day the chemical explosions were not carried out. Unfortunatly, exact time of carrying out of everyone explosion is not registrated by makers of these works. The explosions are carried out in the second half of work day from 13 to 17 hours of local time. 


\section{SHORT CHARACTERISTIC OF SEISMICITY OF REGIONS OF LOCATION OF QUARRIES.}

The territory of Northern and Eastern Kazakhstan in the whole have not great seismic nature. The region of Ekibastuz, where the chemical explosions are carried out in Northern Kazakhstan is aseismical. Let's observe every local region of Eastern Kazakhstan in concrete.

The quarry of Novotaubinka is situated in a seismic region. During 1995 year and the 1st half of 1996 year on the territory of this region wasn't recorded no one of earthquakes. The region of quarry Sazhaevka is bordering with seismic area called Gorny Altay. During observed period of time 6 earthquakes occured with magnitude from 3.9 to 5.4 in square with coordinates 47.5-51 of north latitude and 85-91 of east longitude. The nearest to quarry earthquake occured on 28 of May 1995. The coordinates of epicenter are 47.7 of north latitude and 85.5 of east longitude, magnitude $m=4.8$, depth of source $h=24 \mathrm{~km}$ and time in source $21 \mathrm{~h} 46 \mathrm{~m} 47.7 \mathrm{~s}$.

The region of Alakol quarry is situated near areas with high seismicity. To the south-south-east from the quarry during 1995 year 6 earthquakes was recorded with $m$ from 4.05 to 5.6 . The epicentres of these events are situated on the territory of China in Sinczian-Uigurski autonomous region ( square with coordinates 43-44 of north latitude and 83-85 of east longitude ). To the west and south-west from the quarry the seismogenerated zone Dzhungarskaya is placed, with which 2 earthquakes were $c$ nnected, that happened near from Alakol 
quarry on 28 Sep 1995 ( 44.6 of north latitude and 80.2 of east longitude, $\mathrm{m}=4.8, \mathrm{~h}=23 \mathrm{~km}$, time in source $08 \mathrm{~h} 32 \mathrm{~m} 33.2 \mathrm{~s}$, and on 13 May 1996 ( 45.6 of north latitude, 80.3 of east longitude, $\mathrm{m}=3.5, \mathrm{~h}=33 \mathrm{k}$, time in source $22 \mathrm{~h} 28 \mathrm{~m} 25.6 \mathrm{~s}$ ).

From seismic point of view Southern Kazakhstan is one of the most seismic regions of Middle Asia and Kazakhstan. For obvious idea about the level of seismic activity of region of location of explosion quarries the map of epicentres of earthquake upon instrumental data for 1961 - 1990 yy. with $\mathrm{K}=$ 9-12 was drawn ( Fig.3). How we can see from this map, in whole the epicentres of the earthquakes are distributed irregurarly. Judging from the character of epicentrical field, the main seismic activity is developing at the North-East ( Dzhungarskaya zone) and at the South (Tian-Shanskaya zone) of the region, where the high concentration of epicenteres of earthquakes is observed. The rest of part of region is filled by epicentres of earthqu kes with different density for different regions. Let's stop more detaily on the features of seismicity in the region of disposition of explosion quarries.

The group of quarries Kusakskyi, Zapadnaya, Tekeli and Koksu was timed to Dzhungarskaya zone. The maximum accumulation of epicenteres of earthquakes in the region of desposition of quarries exactly is observed. The focuses of these earthquakes connected with South-Dzhungarskaya seismogenerated zone. The seismic hazard of this zone upon the map of seismic division into districts of Kazakhstan ( $\mathrm{CP}-78$ ) is estimated in force 8, and maximum observed earthquake had a magnitude $m=6.4$.

Quarry Kolpatasskyi, that is situated in the same region, is placed at the western edge of zone Dzhungarskaya and 
characterized by relatively low level of seismicity.

The second group of quarries (Dalabay, Zhalaman and 12a) is situated within the limits of epicenter's range, that extend from the west edge of Dzhungarskaya zone to south-west.

The level of seismic activity of this zone relatively low. The magnitude of maximum observed here earthquake don't exceed $\mathrm{m}$ $=6$.

The third group of quarries ( Kotur-Bulak, Actuz, Georgievka, was spatially timed to Northern Tyan-Shanskaya seismic zone, that is suffer often and strong earthquakes. Among this group the region of Kotur-Bulak quarry is characterized by the most high level of seismic hazard. It is situated in the focuses of the wellknown force 10 Vernenskyi earthquake in 1887 $(\mathrm{m}=7.3)$ and force 10-11 Keminskyi earthquake in $1911(\mathrm{~m}=$ 8.31 .

The level of modern seismic activity of this region is very high. That is corroborated by data of instrumental seismic observes.

The seismic activity of North-Tyan-Shanskaya zone, extending in sublatitude direction from Dzhambyl city $($ on the west) to the territory of China ( on the east) is not the same at the different places. On the one of the weak seismic places 1 upon the level of weak earthquake, of this zone the quarry Aktuz is situated though spatially it is timed to the focus of force 10-11 Keminskyi earthquake of 1911 year.

The frequence of repeating of moderate and strong earthquakes is high enough here. The quarry Georgievka is situated within the limits of Chu-Iliyskaya zone, were the modern seismic activity upon the strong earthquakes not high and 
activity of weak earthquakes, how we can see from the map, enough appreciable.

The forth group of quarries (Koskuduc, Chilbastau and Adeksu, is situated within the bounds of weak seismic zone, for which the single epicenteres of weak earthquakes are characterized. The main seismic hazard for this group of quarries presents North-Tyan-Shanskaya seismic zone, that situated to the south from it on the distance 80-100 kms.

And, at last, quarry Ushalyk is situated actually in aseismic zone where the level of seismic hazard is connected with transit earthquakes and estimated upon the map of seismic division into districts force 5 .

In that way, explosion quarries within the limits of observing region are situated at the different upon degree of seismic hazard places. The regions of quarries, that situated within the limits of North-Tyan-Shanskaya and Dzhungarskaya seismicity zones are known by strong and catastrophical earthquakes in last and active in the present time upon the level both weak and strong earthquakes, and characterized by the great level of seismic hazard.

How we can see from adduced description, in Kazakhstan, particularly in Southern Kazakhstan, there are enough many quarries in the zones of high seismicity. Presence of a rich data base of seismic records of chemical explosions and weak subsurface's earthquakes from one region gives us beatifull possibility for development of methods of determination of chemical explosions and earthquakes. 


\section{SYSTEM OF OBSERVATION AND APPARACY.}

Apparacy, that used in Go " Kurchatov " for record of explosions, accuring at the territory of Northern and Eastern Kazakhstan, was described detaily in report upon Agreement $\mathrm{N}$ B301621. So we don't adduce here it's description, we'll only refer one feature, which is considerably influence upon resultion of observations.

Apparacy of system of group " Cross " have a frequence of digitation equal to 40 reading in sec, but it is equiped by band filters in the entrance. Band of passing of filters equal to $0.5-5 \mathrm{~Hz}$ ( fig.4).

In the same time it is known, that the chemical quarry explosions are more highfrequent ( the maximum of energy of P-wave falls on the frequences about $10 \mathrm{~Hz}$ ). This is considerably hamper the registration and interpretation of seismic records of explosions.

For determination of explosions it would be more comfortable to use broadband station " DAS " with frequence of digitation equal to 200 readings in second, what allows to registrate actually all the frequente components of the signal from chemical explosion.But for this it is necessary to know the time of conduction of explosions with accuracy till the first seconds, as to determine the coordinates of epicenter with help of three-components records of " DAS " stations with admissible accuracy is dificult.

All the rest part of this chapter we'll devote to the description of system of observation and apparacy of seismic 
station of the Institute of Seismology of Ministry of Science of RK and united Institute of Physic of Earth of Russian Academy of Sciences, which was used for registration of chemical explosions at the territory of southern Kazakhstan ( Almaty and Taldy-Kurgan regions $)$.

Special works for recognizing of chemical explosions at the records of seismic stations of the Kazakhstan Republic didn't conducted. Identification of explosions is produced on the base of early installed by empirical way typical features of wave image of records on the determined seismic stations.

For every region of conduction of explosions their own stations were exposed on which such a features reveal more clearly. Figure 1 shows the scheme of distribution of seismic ststions upon records of which pick out the explosions.

The record of seismic events from the explosions is produced by seismic stations with galvanometrical system of record. Seismometricalchannel is consist from seismographs SKM-3 or SM-3, galvanometers GB-4 groupping in block BG-9 with photoregistration on the register RS-PM (fig.5).

These stations are characterised by high sensitivity, broad range of recording frequence, identity of channels and economy.

Complete set such of seismic ststion also consists of the manager desk, the automat of amplification brightness, the magnitoelectrical generator of constant amplitudes (MGCA). All the system of the station works in the united time (GCT).

The registration of seismic events is carried out by three seismometrical channels, that orientate mutually perpendicularly - X, Y, Z. For the record of more strong seismic influences every station has one or three channels with low sensitivity 
with coefficient of coarsening equal 20 with respect to main channels. On the all stations the displacement is registrating kinematical parameter.

Expereance of many years instrumental observations for the weak earthquakeres and quarry explosions show that at the such of stations installed in good condition (main rocks the level of hindrances), the big extensions can be realize and the ground vibrations can be reproduce with little amplitude of distortions. Amplitude - frequence characteristic such of channel has similar to table look in the range of frequencies about 0.5-10 H. These frequencies correspond to seismic events near weak earthquakeres and industrial explosions.

In the capacity of example values of parameteres of system called seismograph SKM-3 - galvanometer GB-4 that is used on the most of seismicstations of Kazakhstan for channel $z$.

Table 8 . The values of parameteres of seismometrical channel.

\begin{tabular}{|c|c|c|}
\hline Parameter & Seismograph & Galvanometer \\
\hline Own frequent $f$ & $0.5 \mathrm{~Hz}$ & $12.3 \mathrm{~Hz}$ \\
\hline The constant of damping D & & 8.5 \\
& & \\
\hline
\end{tabular}




\begin{tabular}{|c|c|c|}
\hline Parameter & Seismograph & Galvanometer \\
\hline $\begin{array}{c}\text { Coefficient of connection of } \\
\text { system } \delta\end{array}$ & 0.0197 & \\
\hline $\begin{array}{c}\text { Increase of channel V } \\
\text { Range of periods, } \\
\text { corresponding to the level of } \\
\text { increase } \\
0.9^{*} \mathrm{~V}\end{array}$ & $5000-60000$ & \\
\hline
\end{tabular}

For example we'll show the results of registration by net of stations and the interpretation of records of explosion of quarry that was prodused on the 17 of May 1995 year. It was registrated by 12 seismic stations of Kazakhstan. One of them Arharly - with telemetrical transmission of information to the center of interpretation in Almaty city, others - stationary.

Interpretation of records was produced in the same way, how it is doing for the local earthquakes.

Method of summary interpretation is following. The time in the focus was determined from diagramm Vadati. The coordinats of hypocenter $\varphi, \lambda, H$ were determined from data of times of first wave arrival of $P$ and $S$ waves with useing of velocity model of Shatsilov V.I.[1]. The power class was determined from nomogram of Rautian T.G.[2]. The magnitude of longitudinal wave MRW was determined from regional calibration curve and nomogram of 
Mihailova N.N., Neverova N. for Northern Tyan-Shan [3]. Below dinamic and kinematic characteristics of records of this explosion upon the all stations were shown and also the results of summary processing.

Table 9. Example of registration of chemical

explosion by the net of seismic stations.

Explosion in the quarry zholaman. May 17

$$
\begin{aligned}
& 1995 \mathrm{y} ., \mathrm{t}=07 \mathrm{~h} 44 \mathrm{m55.0 \textrm {s }}, \varphi=44^{\circ} 16^{\prime}, \\
& \lambda=77^{\circ} 37^{\prime}, \mathrm{H}=0-5 \mathrm{~km}, \mathrm{~V} / \mathrm{V}=1.71 \\
& \text { (Vadati ), } \mathrm{K}=7.5, \mathrm{MPV}=3.5 .
\end{aligned}
$$

\begin{tabular}{|l|l|l|l|l|l|l|}
\hline $\begin{array}{l}\text { Seismic } \\
\text { station }\end{array}$ & \multicolumn{1}{|c|}{$\mathrm{t}$} & $\mathrm{t}-\mathrm{t}$ & $\Delta, \mathrm{km}$ & $\mathrm{K}$ & \\
\hline Arharly & ip 4457.5 & is 4459.5 & 2.0 & 15 & 7.0 & - \\
\hline Chushkaly & ep 45 06.4 & is 45 14.8 & 8.4 & 65 & 7.1 & 3.2 \\
\hline Kuram & ep 45 10.9 & is 45 23.4 & 12.5 & 98 & 7.4 & 3.8 \\
\hline Turgen & ip 45 12.5 & is 45 25.3 & 12.8 & 106 & 7.5 & 3.3 \\
& & & & & & \\
\hline Kurty & ep 45 12.8 & is 45 26.3 & 13.5 & 108 & 7.7 & 3.6 \\
& & & & & & \\
\hline Medeo & ep 45 16.3 & es 45 32.0 & 15.7 & 128 & 7.1 & 3.2 \\
\hline
\end{tabular}




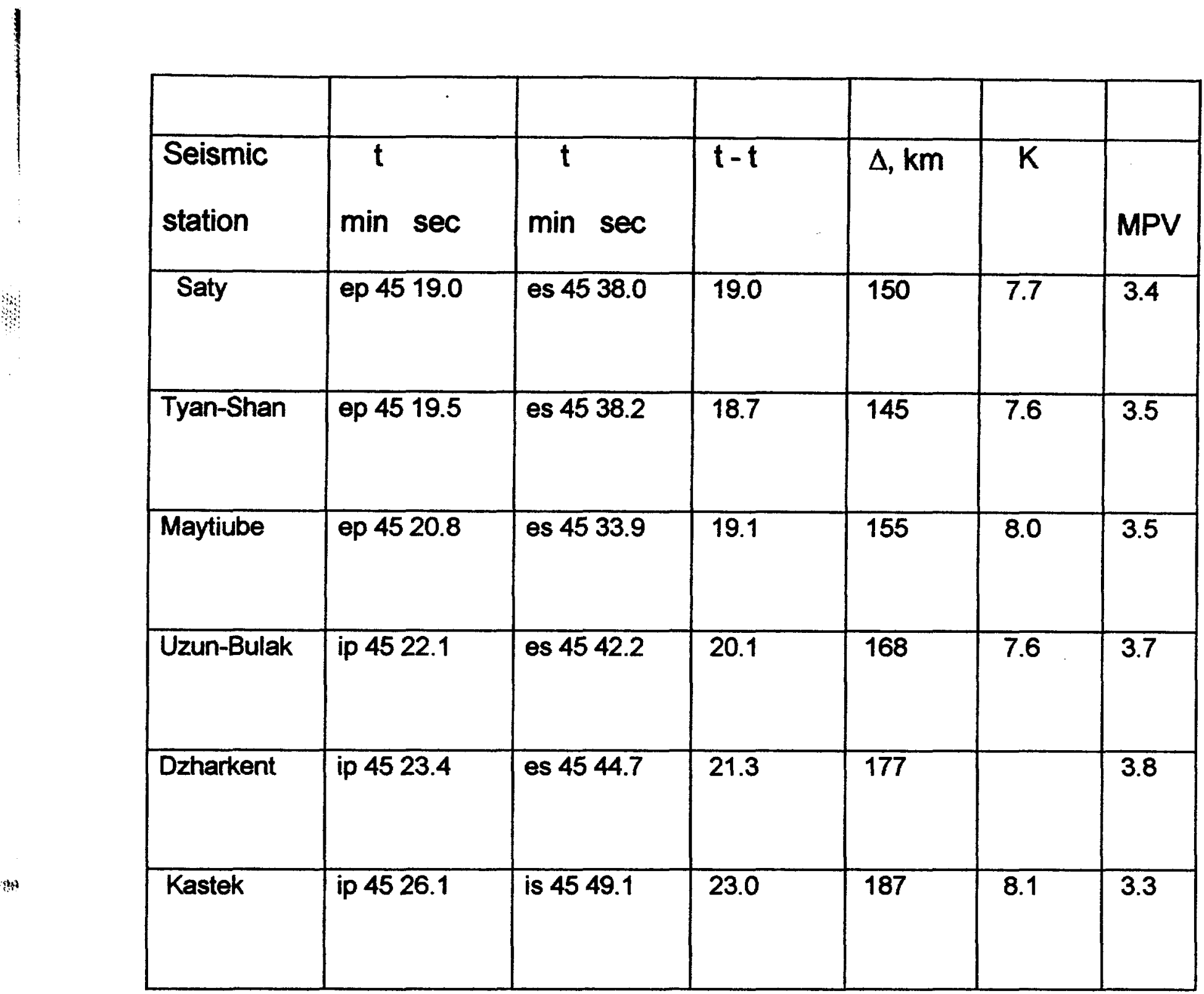

If we'll compare the results of processing of this explosion with real coordinates of zholaman quarry ( table 5 ), then we can see, that $\varphi, \lambda, H$ have a good agreement. The difference in coordinates not more than 2'. Therefore, from the records of available seismic stations it is possible to estimate the parametres of explosions reliably. 


\section{IDENTIFICATION OF CHEMICAC EXPIOSIONS \\ ON THE SEISMTC RECORDS.}

\subsection{Lists of explosions, exposed on the seismic records.}

\subsubsection{Southern Kazakhstan.}

The most succesfull the identification of explosions upon seismic data was carried out on the territory of Southern Kazakhstan. 104 explosions were determined here for 1995 year. The distribution of these explosions upon the power classe $K$ (a) and the time (b) is shown on the figure 7 . The power range of recording chemical explosions consists from 4.5 to 9.5 .

$75 \&$ of all the events connected to range of 6-8 classes. The most strong explosions with $K>9$ were settled by stations Boralday, Southern, Zhabagly. The most weak explosions were settled by settled by stations Tyan-Shan, Turgen, Chushcaly. Upon the time of 24-hours more than $80 \%$ of all the explosions are produced in work time of day, what clearly shown on the distribution (fig. 7b). This is the interval of time from 4 o'clock till 12 olclock upon Greenwich. There are a few number $f$ events outside of this interval. Not exclude, that the some of them are weak earthquakes and their connection to explosion are consequence of errors of interpretation.

The table 10 show the list of recorded explosions. It 
includes the following data:

- The data of explosion;

- The name of station, from records of which the explosion was indicated;

- $t$ - time of the first wave arrival of $P$-wave at this station;

- $t$ - $t$ - the time of delay between $S-$ and P-waves;

- $K$ - class of power, determined from nomogram of Rautian T.G. on the base of measures of amplitudes on the records of explosion on this station;

- The name of quarry, with which this explosion was connected;

- total weight of charge ( upon the data from the explosionmakers ).

The names of stations for short image are: KST - Kastek, T-Sh - Tyan-Shan, Chshk -Chushkaly, Krt -Kurty, Brd -Boralday, Kpa -Kapal-Arasan, U-B -Uzun-Bulak, Zhbg -Zhabagly, Mdo -Medeo, Uzhn -Uzhnaya, T-K -Taldykorgan, Kur -Kuram, Dzhr - Zharkent.

Table 10. Iist of explosions, that were registrated from seismic stations of Southern Kazakhstan during 1995 year. 


\begin{tabular}{|c|c|c|c|c|c|c|c|}
\hline $\mathbf{N}$ & DATE & $t p$ & STATION & $t_{s}-t_{p}$ & $\mathrm{~K}$ & $\begin{array}{l}\text { NAME OF } \\
\text { QUARRY }\end{array}$ & $\begin{array}{c}\text { TOTAL } \\
\text { WEIGHT } \\
\text { OF CHARGE, } \\
\text { kg }\end{array}$ \\
\hline 1 & 05.01 .95 & 105151.0 & $\overline{K s t}$ & 5.0 & 7.3 & Aktuz & \\
\hline 2 & 07.01 .95 & 100920.4 & Chshk & 7.5 & 6.8 & & \\
\hline 3 & 19.01 .95 & 100606.8 & Saty & 3.5 & 7.2 & & \\
\hline 4 & 19.01 .95 & 120247.5 & Kst & 3.7 & 5.7 & Aktuz & \\
\hline 5 & 24.01 .95 & 091451.8 & Krt & 7.4 & 6.4 & Ushalyk & 5.2 \\
\hline 6 & 24.01 .95 & 102615.2 & Krt & 13.6 & 6.6 & Jolaman & 5.7 \\
\hline 7 & 25.01 .95 & 061704.6 & Chshk & 5.4 & 5.9 & & \\
\hline 8 & 30.01 .95 & 091312.8 & U-B & 2.5 & 6.4 & & \\
\hline 9 & 07.02 .95 & 081646.6 & Mdo & 1.4 & 6.7 & Kotur-Bulak & 13.1 \\
\hline 10 & 10.02 .95 & 101303.8 & Kst & 12.0 & 7.1 & Georgievka & \\
\hline 11 & 21.02 .95 & 055829.3 & T-Sh & 3.1 & 5.2 & Lowering of & 0.08 \\
\hline
\end{tabular}




\begin{tabular}{|c|c|c|c|c|c|c|c|}
\hline & & & & & & snow-slip & \\
\hline $\mathbf{N}$ & DATE & $t_{p}$ & STATION & $t_{s}-t_{p}$ & $\bar{K}$ & $\begin{array}{l}\text { NAME OF } \\
\text { QUARRY }\end{array}$ & $\begin{array}{c}\text { TOTAL } \\
\text { WEIGHT } \\
\text { OF CHARGE, } \\
\text { kg }\end{array}$ \\
\hline 12 & 11.03 .95 & 055905.4 & Chshk & 1.6 & 7.0 & & \\
\hline 13 & 11.03 .95 & 061724.8 & Chshk & 8.6 & 7.3 & Zholaman & 14.1 \\
\hline 14 & 11.03 .95 & 064952.5 & Chshk & 1.7 & 4.8 & & \\
\hline 15 & 11.03 .95 & 101415.7 & Chshk & 1.7 & 8.0 & & \\
\hline 16 & 17.03 .95 & 101056.0 & $T-K$ & 6.2 & 7.0 & Koksu & \\
\hline 17 & 17.03 .95 & 135459.3 & Krt & 5.2 & 5.6 & & \\
\hline 18 & 27.03 .95 & 102942.5 & Krt & 7.1 & 8.0 & & \\
\hline 19 & 28.03 .95 & 102753.7 & $T-K$ & $\overline{5.5}$ & 7.8 & Tekeli & \\
\hline 20 & 28.03 .95 & 122753.5 & Trg & 3.6 & 5.6 & $\begin{array}{l}\text { Lowering of } \\
\text { snow-slip }\end{array}$ & 0.1 \\
\hline 21 & 30.03 .95 & 084449.9 & Krt & 7.1 & 7.2 & & \\
\hline
\end{tabular}




\begin{tabular}{|c|c|c|c|c|c|c|c|}
\hline $\mathbf{N}$ & DATE & $t_{p}$ & STATION & $t_{s}-t_{p}$ & $\mathrm{~K}$ & $\begin{array}{l}\text { NAME OF } \\
\text { QUARRY }\end{array}$ & $\begin{array}{c}\text { TOTAL } \\
\text { WEIGHT } \\
\text { OF CHARGE, } \\
\text { kg }\end{array}$ \\
\hline 22 & 31.03 .95 & 060630.4 & $\overline{\mathrm{Krt}}$ & 5.8 & 5.7 & Quarry 12a & \\
\hline 23 & 03.04 .95 & 092003.1 & Trg & 3.8 & 5.0 & $\begin{array}{l}\text { Lowering of } \\
\text { snow-slip }\end{array}$ & 0.1 \\
\hline 24 & 07.04 .95 & 052036.0 & $\overline{K r t}$ & 7.4 & 6.2 & $\begin{array}{l}\text { out-road } \\
\text { excavation }\end{array}$ & 1.7 \\
\hline 25 & 10.04 .95 & 163944.5 & T-Sh & 3.3 & 6.0 & $\begin{array}{l}\text { Lowering of } \\
\text { snow-slip }\end{array}$ & \\
\hline 26 & 12.04 .95 & 114154.8 & U-B & 5.2 & 7.0 & & \\
\hline 27 & 12.04 .95 & 115531.8 & U-B & 3.7 & 7.4 & & \\
\hline 28 & 25.04 .95 & 111048.5 & Brd & 14.1 & 7.2 & & \\
\hline 29 & 27.04 .95 & 061649.1 & Krt & 7.4 & 7.1 & & \\
\hline 30 & 27.04 .95 & 090551.7 & $T-K$ & 3.8 & 7.0 & Kusakskyi & 7.0 \\
\hline 31 & 27.04 .95 & 105025.7 & Krt & 5.7 & 6.5 & & \\
\hline 32 & 30.04 .95 & 102549.0 & Kpa & 14.3 & 7.2 & & \\
\hline
\end{tabular}




\begin{tabular}{|c|c|c|c|c|c|c|c|}
\hline $\bar{N}$ & DATE & $t_{p}$ & STATION & $t_{s}-t_{p}$ & $\bar{K}$ & $\begin{array}{l}\text { NAME OF } \\
\text { QUARRY }\end{array}$ & $\begin{array}{c}\text { TOTAL } \\
\text { WEIGHT } \\
\text { OF CHARGE, } \\
\text { kg }\end{array}$ \\
\hline 33 & 30.04 .95 & 103419.6 & U-B & 3.0 & 5.3 & & \\
\hline 34 & 01.05 .95 & 014955.1 & Saty & 2.5 & 5.5 & & \\
\hline 35 & 03.05 .95 & 100046.0 & Zhbg & 20.7 & 7.9 & & \\
\hline 36 & 11.05 .95 & 090115.8 & Zhbg & 22.8 & 7.6 & & \\
\hline 37 & 12.05 .95 & 053715.0 & Kst & 11.0 & 6.7 & Georgievka & \\
\hline 38 & 16.05 .95 & 114126.0 & $\mathrm{Krt}$ & 5.6 & 6.2 & Quarry $12 a$ & 1.2 \\
\hline 39 & 17.05 .95 & 074510.9 & Krt & 13.5 & 7.8 & Zholaman & 12.6 \\
\hline 40 & 19.05 .95 & 051654.5 & Kst & 10.9 & 6.7 & Georgievka & \\
\hline 41 & 24.05 .95 & 102134.0 & $\overline{K s t}$ & 5.2 & 7.0 & Aktuz & \\
\hline 42 & 26.05 .95 & 065604.0 & Chshk & 1.5 & 7.0 & & \\
\hline
\end{tabular}




\begin{tabular}{|c|c|c|c|c|c|c|c|}
\hline $\mathbf{N}$ & DATE & $t_{p}$ & STATION & $t_{s}-t_{p}$ & $\mathrm{~K}$ & $\begin{array}{l}\text { NAME OF } \\
\text { QUARRY }\end{array}$ & $\begin{array}{c}\text { TOTAL } \\
\text { WEIGHT } \\
\text { OF CHARGE, } \\
\text { kg }\end{array}$ \\
\hline 43 & 01.06 .95 & 110757.1 & Krt & 6.1 & 6.5 & Quarry $12 a$ & \\
\hline 44 & 05.06 .95 & 052654.0 & Kst & 5.0 & 6.9 & Aktuz & \\
\hline 45 & 07.06 .95 & 083909.6 & Mdo & 1.5 & 7.0 & Kotur-Bulak & \\
\hline 46 & 09.06 .95 & 105509.2 & $\mathrm{Krt}$ & 5.9 & 6.3 & Quarry 12a & \\
\hline 47 & 16.06 .95 & 080316.1 & Kst & 11.0 & 7.0 & Georgievka & \\
\hline 48 & 21.06 .95 & 035526.7 & $\mathrm{Krt}$ & 7.8 & 7.0 & & \\
\hline 49 & 21.06 .95 & 053538.8 & Krt & 6.9 & 6.2 & Quarry $12 a$ & \\
\hline 50 & 30.06 .95 & 010449.4 & Chshk & 2.0 & 6.7 & & \\
\hline 51 & 30.06 .95 & 170250.9 & T-Sh & 2.7 & 8.0 & $\begin{array}{l}\text { Lowering of } \\
\text { snow-slip }\end{array}$ & \\
\hline 52 & 07.07 .95 & 100532.7 & $\overline{\text { Kst }}$ & 8.3 & 6.4 & Ushalyk & 5.0 \\
\hline 53 & 14.07 .95 & 092227.8 & $\overline{\mathrm{Krt}}$ & 13.5 & 7.8 & Zholaman & 11.05 \\
\hline
\end{tabular}




\begin{tabular}{|c|c|c|c|c|c|c|c|}
\hline $\mathbf{N}$ & DATE & $t_{p}$ & STATION & $t_{s}-t_{p}$ & $\bar{K}$ & $\begin{array}{l}\text { NAME OF } \\
\text { QUARRY }\end{array}$ & $\begin{array}{c}\text { TOTAL } \\
\text { WEIGHT } \\
\text { OF CHARGE, } \\
\text { kg }\end{array}$ \\
\hline 54 & 17.07 .95 & 102922.4 & $\overline{K r t}$ & 18.0 & 6.8 & Georgievka & \\
\hline 55 & 22.07 .95 & 145922.6 & Chshk & 3.4 & 5.8 & & \\
\hline 56 & 22.07 .95 & 214751.2 & Kst & 14.0 & 7.1 & & \\
\hline 57 & 26.07 .95 & 195941.4 & Krt & 22.6 & 7.4 & & \\
\hline 58 & 28.07 .95 & 104816.2 & Uzhn & 22.5 & 8.9 & & \\
\hline 59 & 28.07 .95 & 105912.7 & Uzhn & 21.5 & 8.1 & & \\
\hline 60 & 03.08 .95 & 100245.5 & Kst & 11.2 & 6.7 & Georgievka & 5.0 \\
\hline 61 & 09.08 .95 & 095445.3 & Kst & 11.0 & 7.0 & Georgievka & \\
\hline 62 & 28.08 .95 & 054335.2 & Krt & 7.5 & 5.8 & & \\
\hline 63 & 30.08 .95 & 050552.0 & T-K & 6.5 & 7.4 & Kusakskyi & 6.8 \\
\hline
\end{tabular}




\begin{tabular}{|c|c|c|c|c|c|c|c|}
\hline $\mathbf{N}$ & DATE & $t_{p}$ & STATION & $t_{s}-t_{p}$ & K & $\begin{array}{l}\text { NAME OF } \\
\text { QUARRY }\end{array}$ & $\begin{array}{c}\text { TOTAL } \\
\text { WEIGHT } \\
\text { OF CHARGE, } \\
\mathrm{kg}\end{array}$ \\
\hline 64 & 01.09 .95 & 162056.3 & Saty & 2.4 & 5.5 & & \\
\hline 65 & 06.09 .95 & 094439.3 & Chshk & 3.2 & 6.6 & & \\
\hline 66 & 06.09 .95 & 113959.1 & Chshk & 9.0 & 7.4 & Zholaman & 12.1 \\
\hline 67 & 07.09 .95 & 003709.3 & Cur & 6.0 & 5.9 & & \\
\hline 68 & 07.09 .95 & 092801.7 & Kst & 11.0 & 6.9 & Georgievka & \\
\hline 69 & 11.09 .95 & 124926.6 & Krt & 5.2 & 6.2 & & \\
\hline 70 & 21.09 .95 & 045305.0 & Chshk & 1.8 & 7.0 & & \\
\hline 71 & 21.09 .95 & 094435.0 & Kst & 10.7 & 7.0 & & \\
\hline 72 & 02.10 .95 & 111148.7 & Brd & 7.9 & 6.5 & & \\
\hline 73 & 04.10 .95 & 101613.6 & Uzhn & 17.0 & 8.4 & & \\
\hline 74 & 07.10 .95 & 104329.5 & Brd & 13.0 & 7.3 & & \\
\hline
\end{tabular}




\begin{tabular}{|c|c|c|c|c|c|c|c|}
\hline $\mathbf{N}$ & DATE & $t_{p}$ & STATION & $t_{s}-t_{p}$ & $\bar{K}$ & $\begin{array}{l}\text { NAME OF } \\
\text { QUARRY }\end{array}$ & $\begin{array}{c}\text { TOTAL } \\
\text { WEIGHT } \\
\text { OF CHARGE, } \\
\text { kg }\end{array}$ \\
\hline 75 & 10.10 .95 & 095126.1 & Brd & 10.6 & 6.6 & & \\
\hline 76 & 10.10 .95 & 101754.4 & Uzhn & 18.6 & 8.4 & & \\
\hline 77 & 11.10 .95 & 050702.1 & Chshk & 1.7 & 5.2 & & \\
\hline 78 & 21.10 .95 & 071140.7 & Kst & 11.6 & 6.6 & Georgievka & \\
\hline 79 & 02.11 .95 & 024920.5 & T-K & 4.8 & 4.7 & Kusakskyi & \\
\hline 80 & 02.11 .95 & 104744.8 & Uzhn & 21.1 & 8.4 & & \\
\hline 81 & 03.11 .95 & 022427.5 & Kst & 6.3 & 7.1 & & \\
\hline 82 & 04.11 .95 & 062444.8 & T-K & 6.3 & 8.2 & Kusakskyi & 8.2 \\
\hline 83 & 04.11 .95 & 092851.0 & Saty & 16.0 & 6.9 & & \\
\hline 84 & 04.11 .95 & 150356.8 & U-B & 13.5 & 6.8 & & \\
\hline
\end{tabular}




\begin{tabular}{|c|c|c|c|c|c|c|c|}
\hline$N$ & DATE & $t_{p}$ & STATION & $t_{s}-t_{p}$ & $\mathrm{~K}$ & $\begin{array}{l}\text { NAME OF } \\
\text { QUARRY }\end{array}$ & $\begin{array}{c}\text { TOTAL } \\
\text { WEIGHT } \\
\text { OF CHARGE, } \\
\mathrm{kg}\end{array}$ \\
\hline 85 & 06.11 .95 & 105111.4 & Brd & 14.2 & 6.9 & & \\
\hline 86 & 08.11 .95 & 102959.6 & Uzhn & 20.2 & 7.7 & & \\
\hline 87 & 10.11 .95 & 043851.9 & $\mathrm{Kpa}$ & 8.5 & 7.1 & & \\
\hline 88 & 10.11 .95 & 105620.5 & Brd & 11.4 & 7.6 & & \\
\hline 89 & .10 .11 .95 & 110907.7 & Uzhn & 18.5 & 7.4 & & \\
\hline 90 & 13.11 .95 & 072322.1 & $\overline{K r t}$ & 18.9 & 7.1 & & \\
\hline 91 & 15.11 .95 & 025951.7 & Dzhr & 6.5 & 5.8 & & \\
\hline 92 & 16.11 .95 & 104056.9 & Uzhn & 11.3 & 8.5 & & \\
\hline 93 & 20.11 .95 & 000716.3 & Dzhr & 10.9 & 7.1 & & \\
\hline 94 & 23.11 .95 & 105229.8 & Uzhn & 21.0 & 9.5 & & \\
\hline 95 & 24.11 .95 & 102134.0 & Chshk & 9.5 & 7.7 & Zholaman & 12.9 \\
\hline
\end{tabular}




\begin{tabular}{|c|c|c|c|c|c|c|c|}
\hline $\mathbf{N}$ & DATE & $t p$ & STATION & $t_{s}-t_{p}$ & $\bar{K}$ & $\begin{array}{l}\text { NAME OF } \\
\text { QUARRY }\end{array}$ & $\begin{array}{c}\text { TOTAL } \\
\text { WEIGHT } \\
\text { OF CHARGE, } \\
\text { kg }\end{array}$ \\
\hline 96 & 27.11 .95 & 110910.0 & $\overline{\mathrm{Krt}}$ & $\overline{17.5}$ & 6.7 & & \\
\hline 97 & 06.12 .95 & 062414.5 & Kst & 11.2 & 6.6 & Georgievka & \\
\hline 98 & 12.12 .95 & 090616.4 & Uzhn & 20.9 & 8.6 & & \\
\hline 99 & 14.12 .95 & 060341.9 & Mdo & 2.1 & 7.1 & Kotur-Bulak & \\
\hline 100 & 15.12 .95 & 070240.1 & Dzhr & 12.0 & 8.5 & & \\
\hline 101 & 15.12 .95 & 085825.2 & Uzhn & 17.5 & 7.8 & & \\
\hline 102 & 15.12 .95 & 094131.8 & Uzhn & 23.5 & 9.4 & & \\
\hline 103 & 17.12 .95 & 084017.3 & T-K & 4.0 & 7.4 & Kusakskyi & 6.4 \\
\hline 104 & 26.12 .95 & 064822.4 & Kst & 5.0 & 6.3 & Aktuz & \\
\hline
\end{tabular}




\subsubsection{Eastern Kazakhstan.}

For the registration of chemical explosions on the territory of Eastern Kazakhstan ( so as Northern) the system of grouping " Cross " was used, which has, how indicated above, not enough broadband of permission of entrance filters, what maked the registration and identification of explosions difficult of acces.

The chemical explosions on the territory of Northern Kazakhstan are recorded relatively not bad, but the explosions at Eastern Kazakhstan practically aren't separable from noise in most causes. Probably, beside of cutting off of high frequences of signal by band filters SG " Cross ", the registration is made difficult to acces by unfavourable configuration of explosions. If the slowing down during explosion consists $35-30 \mathrm{~ms}$ on the one step in the Northern Kazakhstan, this mesure in the Eastern Kazakhstan is considerably more ( however exact mesure was not reported by maker of explosions ).

Table 11. List of events, registrated by system of grouping called " Cross " and identificated like chemical explosions on the territory of Eastern Kazakhstan. 
Upon the data of explosion-makers in Novotaubinka for 19.12.95, explosion was produced with total power equal to 7531 kg. In Sazhaevka ( 01.11.95) explosion was produced with 44968 $\mathrm{kg}$ of explosive. Table include events, which occured not only on the quarries, described above, but and on the other regions of Eastern Kazakhstan, and also on the adjacent territories ( Altay, Kuzbuss, Hakaziya, Balhash ).

\subsubsection{Northern Kazakhstan.}

How it was indicated above, our information upon this territory in the present account was represented only by illustration. In the table 12 for example shown the data of several explosions, which were produced in the quarries of Ekibast $z$. In the whole at the present day Northern Kazakhstan the huge reserve for continuation of works for creation of data base upon the chemical quarry explosions.

The comparison of coordinates of quarries and calculated epicenters of explosions as the comparison of real and calculated coordinates of quarries in the Eastern Kazakhstan testifies, that the epicenters of seismic events are determinate until with low degrees of truth. So proceeding from the location of Ekibastuz quarry, the difference between the coordinates of explosions upon the latitude mustn't to exceed 42', and upon the instrumental calculations this difference reaches 1.79 . he necessity of calibration of seismic station and improving algorithms of localization of seismic events absolutly clear follows from this. 
Table 12. List of events, that were registrated by system of grouping, called " Cross ", and were identificated as chemical explosions on the coal quarries of Ekibastuz.

\begin{tabular}{|c|c|c|c|c|c|}
\hline \multirow[t]{2}{*}{ Date } & \multirow{2}{*}{$\begin{array}{l}\text { Azimuth of } \\
\text { wave's } \\
\text { arrival }\end{array}$} & \multirow{2}{*}{$\begin{array}{c}\text { Azimuthal } \\
\text { velocity, } \\
\mathrm{km} / \mathrm{s}\end{array}$} & \multicolumn{2}{|c|}{$\begin{array}{c}\text { Calculated coordinates } \\
\text { of source, }^{\circ}\end{array}$} & \multirow[t]{2}{*}{$\begin{array}{c}\text { Time in the } \\
\text { source }\end{array}$} \\
\hline & & & latitude & longitude & \\
\hline 01.11 .95 & 311.2 & 5.93 & 51.64 & 75.6 & $08: 51: 48.0$ \\
\hline 19.12 .95 & 302.65 & 6.06 & 52.07 & 75.6 & $07: 21: 08.5$ \\
\hline 19.12 .95 & 302.22 & 6.06 & 52.22 & 76.2 & $07: 59: 04.3$ \\
\hline 19.12 .95 & 294.2 & 7.25 & 50.68 & 75.67 & $08: 12: 14.0$ \\
\hline 19.12 .95 & 300.83 & 5.96 & 51.45 & 75.8 & $08: 35: 42.0$ \\
\hline 19.12.95 & 290.0 & 6.1 & 51.36 & 75.15 & $08: 47: 45.5$ \\
\hline 19.12 .95 & 301.2 & 6.2 & 50.73 & 75.37 & 08:50:03.3 \\
\hline 19.12 .95 & 291.73 & 6.0 & 51.39 & 75.25 & $09: 07: 50.5$ \\
\hline
\end{tabular}




\begin{tabular}{|c|c|c|c|c|c|}
\hline Date & $\begin{array}{l}\text { Azimuth of } \\
\text { wave's } \\
\text { arrival }\end{array}$ & $\begin{array}{c}\text { Azimuthal } \\
\text { velocity, } \\
\mathrm{km} / \mathrm{s}\end{array}$ & $\begin{array}{r}\text { Calculate } \\
\text { of s } \\
\text { latitude }\end{array}$ & $\begin{array}{l}\text { oordinates } \\
\text { ce, } \\
\text { longitude }\end{array}$ & $\begin{array}{c}\text { Time in the } \\
\text { source }\end{array}$ \\
\hline 11.04 .96 & 301.78 & 5.98 & 52.03 & 76.06 & $09: 00: 21.3$ \\
\hline 11.04 .96 & 301.4 & 6.06 & 51.13 & 74.86 & $09: 06: 05.3$ \\
\hline 11.04 .96 & 291.2 & & 51.22 & 75.96 & $09: 11: 23.2$ \\
\hline 11.04 .96 & 304.9 & 6.2 & 50.43 & 76.39 & $09: 26: 00.7$ \\
\hline 11.04 .96 & 299.9 & 5.94 & 51.67 & 75.18 & $09: 40: 35.0$ \\
\hline 11.04 .96 & 302.26 & & 51.48 & 76.3 & $10: 03: 05.6$ \\
\hline
\end{tabular}

\subsection{Correlations between the power}

\section{class and summary weight of charge.}

From data about the summary weight of charge (Q) and power class $K$ of explosions, that we possess, the correlations $\mathrm{K}=$ K(Q) were studied. Firstly, such a correlation was researched upon the all of materials about explosions at the Northern Tyan-Shan. Data about explosions in the region Medeo in 1966 and 1972-1975 YY., that were produced for building of protection 
dam, were used. There were data upon 95 explosions. The data upon explosions of quarry of kotur-Bulak ( total amount of explosions - 20) for period since 1972 till 1974 years are present also. For period since 1973 till 1974 the data upon the building explosi us from the region Kapchagay ( total amount of explosions - 5) are present. Besides this, for period since 1993 till 1994 yy. the data about explosions on the three near siuated quarries, that are placed near Taldykorgan city, are present. These are the Zapadnyi, Tekely and Koksu quarries.

In the second, $K=K(Q)$ were learned separately upon the results of registration of chemical explosions on the territory of South Kazakhstan during 1995 year. In all the information about the value $Q$ only 19 explosions are present. On the figure 8 the diagramm of dependence $K$ and $Q$ from all of the data about explosions at the Northern Tyan-Shan are shown. Equation of regression have an image:

$$
\mathrm{K}=1.52 \cdot \lg \mathrm{Q}(\mathrm{kg})+1.64
$$

Accuracy of estimations from solved equation of regression equal to 1 unit upon K. Figure 8 show, that the data upon the separate quarries from specific features group by sertain manner and the own dependences $K=K(Q)$ can be found for $t$ em. So, the points, that characterize explosions at the quarry Kotur-Bulak are situated in the main above the regress line that was drown upon all of the data. Points upon the iron explosions in the Taldykorgan region are enough well connected by fou ded 
dependence.

The same figure show the line of regression, founded upon the limited data of Aptikaev F.F. (1969). Taking into account the new data upon the Northern Tyan-Shan, we can say, that this dependence unsatisfactorily describe them, so as the ost of points for explosions with $K=5-9$ are situated below of the line of regression.

The data for 1995 year are separately adduced on the fig. 9. The same figure show the line of regression, according to all of the present data. Within the limits of this range according to

$$
\mathrm{K}=1.52 \cdot \lg \mathrm{Q}(\mathrm{kg})+1.64( \pm 1)
$$

about 908 of experience points are situated.

\subsection{Examples of records of explosions.}

\subsubsection{Southern Kazakhstan.}

Southern Kazakhstan is distinguished by rich set of records of events, that are identificated like chemical explosions. The principle of selection of examples for present report was following:

1. One event was recorded by several stations;

2. One station made the records of explosions from 
different quarries. Besides, for one and the same quarry examples of different explosions were shown. 20 records of explosions from 7 explosion areas from 12 explosions were presented in total. Examples of records of explosions in Kotur-Bulak from Febrary 7 and June 7 were shown upon 4 and 3 stations accordingly, explosions in Jolaman and Georgivka - upon 2 stations.

The list of presented copies of records is adduced in table 13.

The distribution of channels of records for all stations is unified. The vertical channel $\mathrm{Z}$ is the lowest at the seismogramm. Then the channel E-W is following, then $\mathrm{N}-\mathrm{S}$. The fourth channel at the several stations is the channel of low sensitivi y ( CLS). The parametres of apparacy for concrete stations are shown in table 14 .

Table 13. List of copies of explosions in Southern Kazakhstan.

\begin{tabular}{|c|c|c|c|c|}
\hline DATA & TIME & STATION & $\begin{array}{c}\text { NUMBER } \\
\text { OF FIGURE }\end{array}$ & QUARRY, REGION \\
\hline 5.01 .95 & 1051 & Kastek & 10 & Aktiuz \\
\hline 7.02 .95 & 0816 & Talgar & 11 & Kotur-Bulak \\
& & Tian-Shan & 12 & \\
& & Almaty & 13 & \\
\hline
\end{tabular}




\begin{tabular}{|c|c|c|c|c|}
\hline & & Medeu & 14 & \\
\hline 10.02 .95 & 1013 & $\begin{array}{l}\text { Kastek } \\
\text { Kurty }\end{array}$ & $\begin{array}{l}15 \\
16\end{array}$ & Georgievka \\
\hline 28.03 .95 & 1027 & Taldykorgan & 17 & Tekeli \\
\hline 17.05 .95 & 0745 & $\begin{array}{l}\text { Kurty } \\
\text { Kastek }\end{array}$ & $\begin{array}{l}18 \\
19\end{array}$ & Jolaman \\
\hline 24.05 .95 & 1021 & Kastek & 20 & Aktiuz \\
\hline 07.06 .95 & 0839 & $\begin{array}{l}\text { Almaty } \\
\text { Tian-Shan } \\
\text { Medeu }\end{array}$ & $\begin{array}{l}21 \\
22 \\
23\end{array}$ & Kotur-Bulak \\
\hline 16.06 .95 & 0803 & Kastek & 24 & Georgievka \\
\hline 14.07 .95 & 0922 & Kastek & 25 & Jolaman \\
\hline
\end{tabular}




\begin{tabular}{|c|c|c|c|c|}
\hline & & Kurty & 26 & \\
\hline 10.10 .95 & 1017 & Jujnaya & 27 & didn't determine \\
\hline 15.12 .95 & 0702 & Jujnaya & 28 & didn't determine \\
& & & & \\
\hline 17.12 .95 & 0840 & Taldykorgan & 29 & Kuksaksky \\
& & & & \\
\hline
\end{tabular}

Table 14. Parametres of apparacy of seismic stations, the copies of records of which were used in report for example.

\begin{tabular}{|c|c|c|c|c|}
\hline STATION & SENSOR & $\overline{V_{m}}$ & $T_{m}, s$ & CHANNELS \\
\hline Jujnaya & $\overline{S K M}$ & 10000 & $0.1-1.4$ & Z,N-S,E-W \\
\hline Taldykorgan & SKM & $\begin{array}{c}10380 \\
518\end{array}$ & $\begin{array}{l}0.15-1.45 \\
0.15-1.45\end{array}$ & $\bar{N}-\mathrm{S}$ \\
\hline Kastek & SKM & $\begin{array}{l}40500 \\
2030\end{array}$ & $\begin{array}{l}0.1-1.5 \\
0.1-1.5\end{array}$ & $\begin{array}{c}\text { Z, N-S, E-W } \\
\text { E-W }\end{array}$ \\
\hline Kurty & SKM & 40150 & $0.1-1.4$ & Z,N-S,E-W \\
\hline
\end{tabular}




\begin{tabular}{|c|c|c|c|c|}
\hline & & & & \\
\hline Medeu & SKM & 40150 & $0.1-1.4$ & Z,N-S,E-W \\
\hline Tian-Shan & SKM & 40100 & $0.1-1.5$ & Z,N-S,E-W \\
\hline Almaty & SKM & 5000 & $0.1-1.3$ & Z,N-S,E-W \\
& & & & Z,N-S,E-W \\
& & 250 & $0.1-1.3$ & Z,N-S,E-W \\
\hline Talgar & SM-2 & 60000 & $0.1-1.4$ & \\
& & & & \\
\hline
\end{tabular}

\subsubsection{Eastern Kazakhstan.}

17 examples of records from 9 events, that took a place at the 8 areas - Novotaubinka, Sajaevka, Semipalatinsk city, Achinsk city, Abakan city, Kounradskii settlement, Sayak settlement, Ust-Koksa settlement are shown on fig. 30-46. The areas wi h epicenteres of last 6 events are not the quarries of Goverment joint-stock company " Jarilis ", and events, that were recorded on them, can be both the explosions, that were carried out by unknown organisations, and weak earthquakes.

The records are presented in following two variants:

1. Seismogramms of all sensors of "Cross ", that were in order at the moment of registration 1 the total number of sensors is 21, but not the all sensors are working good, for 
example, 03.05.1995 all the 21 sensors made a record qualitatevely, but 11.04.1996 - only 13/. From these records the azimut of signal arrival and azimutal velocity are determined very well.

2. The seismogramms of border northern, southern, eastern and western sensors of " Cross ", that were in good condition. On these records we can see the detail wave picture of event on a large vertical scales.

4.3.3. Northern Kazakhstan.

On the fig. 47-68 shown 22 examples of records from 14 explosions in the region of Ekibastuz.

m

59 


\section{CONCIUSION}

The data about industrial explosions, that were produced in 1995 and first half of 1996 year in Southern, Eastern and Northern Kazakhstan, are presented here.

Created data base can be used for solving of following tasks :

1. Upon the data base of explosions and earthquakes from one region to continue improving of methods of reckognizing of explosions and earthquakes.

2. To use the records of industrial explosions for calibration of seismic stations ( Borovoe, Kurchatov, Makanchi ) and for improving of algorythms of localization of epicenteres. With the similar aims we can conclude a contract with explosion-makers, in Ekibastuz for example, upon which the seismologists will receive the data about exact time of production, exact coordinates, power and configuration of explosions.

It is necessary to note, that represented data base doesn't claim on the plentitude, and it can be increased greatly. We have following opportunity for this:

1. The volume of data base can be essentially increased at the expence of including of total information about chemical explosions at the coal quarries of Ekibastuz.

2. It is possible to increase the amount of contacts with organizations-makers of explosions, both at the old and at the new territories - in Western Kazakhstan, for example.

3. Information for more broad interval of time can be 
included in data base. 


\section{IIST OF IITERATURE}

1. Shatsilov V.I. Method of mass definition of coordinates of epicenteres of local earthquakes. // Problems of prognosis of earthquakes. Dushanbe: Donish, 1982, issue 2. P. 173-195.

2. Rautian T.G. About definition of power of earthquakes on the distances till $3000 \mathrm{~km}$. // Experimental sesmology M.: Science, 1964. P. 88-93.

3. Mihailova N.N., Neverova I.P. Calibrational curve for definition of magnitude MPVA of earthquakes of Northern Tyan-Shan. // Complex researches on the prognosis polygon of Almaty city. Almaty: Science, 1986.

4. Aptikaev F.F. Seismic events in the time of earthquakes and explosions. M.: Science, 1969. P. 103. 


\section{ILIUSTRATIONS TO THE TEXT.}

$\mathbf{N}$

Name of figure

page

of fig.

1 Scheme of distribution of quarries and seismic

stations on the territory of Southern Kazakhstan.

2 Scheme of distribution of coal quarries in envi-

rons of Ekibastuz c.

3 The map of epicenteres of earthquakes, that hap-

pened on the territory of Southern Kazakhstan in

$1961-1990$ YY.

4 Amplitude-frequencial characteristic of sensors

of system of grouping " Cross ".

5 Block-scheme of seismometrical channel

6 Amplitude-frequencial charasteristics of seismic

channels for stations:

1 - Almaty;

2 - Kastek;

3 - КПт Almaty;

4 - Кпч Kastek.

7 Distribution of explosions, that were registrated

on the territory of Southern Kazakhstan:

a) for power class;

b) for the day time. 
8 Connection between the total weight of charge $Q$ and power class of explosions ( upon the information about explosions on the Northern Tyan-Shan in 1966, 1972-1975 and 1993-1994 yy. )

Regions of explosions:

1 - Medeo;

2 - Kotur-Bulak;

3 - Kapchagay;

4 - Quarries Western, Tekely, Koksu;

5 - the line of regression $K=1.52 \mathrm{lg} Q(\mathrm{~kg})+1.64$

6 - upon data of Aptikaev, 1969.

9 Connection between the total weight of charge $Q$ and power class of explosions in Southern Kazakhstan upon the data for 1995 year.

10 Example of record of chemical explosion 05.01 .95 ( quarry Aktuz, seismic station Kastek ).

11 Example of record of chemical explosion 07.02 .95 ( quarry Kotur-Bulak, seismic station Talgar ).

12 Example of record of chemical explosion 07.02 .95 ( quarry Kotur-Bulak, seismic station Tyan-Shan).

13 Example of record of chemical explosion 07.02 .95 ( quarry Kotur-Bulak, seismic station Almaty) .

14 Example of record of chemical explosion 07.02 .95 ( quarry Kotur-Bulak, seismic station Medeo ).

15 Example of record of chemical explosion 10.02 .95

( quarry Georgievka, seismic station Kastek ).

16 Example of record of chemical explosion 10.02 .95 ( quarry Georgievka, seismic station Kurty) .

17 Example of record of chemical explosion 28.03.95 
( quarry Tekeli, seismic station Taldykorgan ).

18 Example of record of chemical explosion 17.05 .95

( quarry Zholaman, seismic station Kurty).

19 Example of record of chemical explosion 17.05.95

( quarry Zholaman, seismic station Kastek).

20 Example of record of chemical explosion 24.05.95

( quarry Aktuz, seismic station Kastek).

21 Example of record of chemical explosion 07.06 .95

( quarry Kotur-Bulak, seismic station Almaty).

22 Example of record of chemical explosion 07.06 .95

( quarry Kotur-Bulak, seismic station Tyan-Shan ).

23 Example of record of chemical explosion 07.06 .95

( quarry Kotur-Bulak, seismic station Medeo ).

24 Example of record of chemical explosion 16.06 .95

( quarry Georgievka, seismic station Kastek ).

25 Example of record of chemical explosion 14.07 .95

( quarry Zholaman, seismic station Kastek ).

26 Example of record of chemical explosion 14.07 .95

( quarry Zholaman, seismic station Kurty).

27 Example of record of chemical explosion 10.10 .95

( quarry was not determined, seismic station Southern .

28 Example of record of chemical explosion 15.12 .95

( quarry was not determined, seismic station Southern ).

29 Example of record of chemical explosion 17.12 .95

( quarry Kusakskyi, seismic station Taldykorgan ).

30 Example of record of chemical explosion 03.05.95

( Semipalatinsk city, all the sensors of "Cross"). 
31 Example of record of chemical explosion 03.05.95

( Semipalatinsk city, the last sensors of "Cross").

32 Example of record of chemical explosion 01.11 .95

( Sajaevka, the last sensors of "Cross").

33 Example of record of chemical explosion 19.12.95

( Novotaubinka, all the sensors of "Cross").

34 Example of record of chemical explosion 19.12.95

( Novotaubinka, the last sensors of "Cross").

35 Example of record of chemical explosion 19.12 .95

(Achinsk city, all the sensors of "Cross").

36 Example of record of chemical explosion 19.12.95

( Achinsk city, the last sensors of "Cross").

37 Example of record of chemical explosion 19.12 .95

( Abakan city, all the sensors of "Cross").

38 Example of record of chemical explosion 19.12.95

( Abakan city, the last sensors of "Cross").

39 Example of record of chemical explosion 19.12.95

( Kounradskyi sett., all the sensors of "Cross").

40 Example of record of chemical explosion 19.12.95

( Kounradskyi sett., the last sensors of "Cross").

41 Example of record of chemical explosion 19.12 .95

( Sayak sett., all the sensors of "Cross").

42 Example of record of chemical explosion 19.12.95

( Sayak sett., the last sensors of "Cross").

43 Example of record of chemical explosion 11.04 .96

( Kounradskyi sett., all the sensors of "Cross").

44 Example of record of chemical explosion 11.04 .96

( Kounradskyi sett., the last sensors of "Cross").

45 Example of record of chemical explosion 12.04 .96 
(Ust-Koksa sett., all the sensors of "Cross").

46 Example of record of chemical explosion 12.04 .96

( Ust-Koksa sett., the last sensors of "Cross").

47 Example of record of chemical explosion 01.11 .95

( Ekibastuz city, all the sensors of "Cross").

48 Example of record of chemical explosion 01.11 .95

(Ekibastuz city, the last sensors of "Cross").

49 Example of record of chemical explosion 19.12.95

(Ekibastuz, 07:21:08, all the sensors of "Cross").

50 Example of record of chemical explosion 19.12.95

(Ekibastuz, 07:21:08, the last sensors of "Cross").

51 Example of record of chemical explosion 19.12 .95

(Ekibastuz, 07:59:04, all the sensors of "Cross").

52 Example of record of chemical explosion 19.12.95

(Ekibastuz, 07:59:04, the last sensors of "Cross").

53 Example of record of chemical explosion 19.12.95

(Ekibastuz, 08:12:14, all the sensors of "Cross").

54 Example of record of chemical explosion 19.12 .95

(Ekibastuz, 08:12:14, the last sensors of "Cross").

55 Example of record of chemical explosion 19.12 .95

(Ekibastuz, 08:35:42, all the sensors of "Cross").

56 Example of record of chemical explosion 19.12.95

(Ekibastuz, 08:35:42, the last sensors of "Cross").

57 Example of record of chemical explosion 19.12.95

(Ekibastuz, 08:07:45, the last sensors of "Cross").

58 Example of record of chemical explosion 19.12 .95

(Ekibastuz, 08:50:03, all the sensors of "Cross").

59 Example of record of chemical explosion 19.12 .95

(Ekibastuz, 08:50:03, the last sensors of "Cross"). 
60 Example of record of chemical explosion 19.12.95

(Ekibastuz, 09:07:50, all the sensors of "Cross").

61 Example of record of chemical explosion 19.12.95

( Ekibastuz, 09:07:50, the last sensors of "Cross").

62 Example of record of chemical explosion 11.04 .96

(Ekibastuz, 09:00:21, all the sensors of "Cross").

63 Example of record of chemical explosion 11.04 .96

(Ekibastuz, 09:00:21, the last sensors of "Cross").

64 Example of record of chemical explosion 11.04 .96

(Ekibastuz, 09:06:05, all the sensors of "Cross").

65 Example of record of chemical explosion 11.04.96

(Ekibastuz, 09:11:23, all the sensors of "Cross").

66 Example of record of chemical explosion 11.04 .96

(Ekibastuz, 09:26:01, all the sensors of "Cross").

67 Example of record of chemical explosion 11.04 .96

(Ekibastuz, 09:40:35, all the sensors of "Cross").

68 Example of record of chemical explosion 11.04 .96

(Ekibastuz, 10:03:05, all the sensors of "Cross"). 

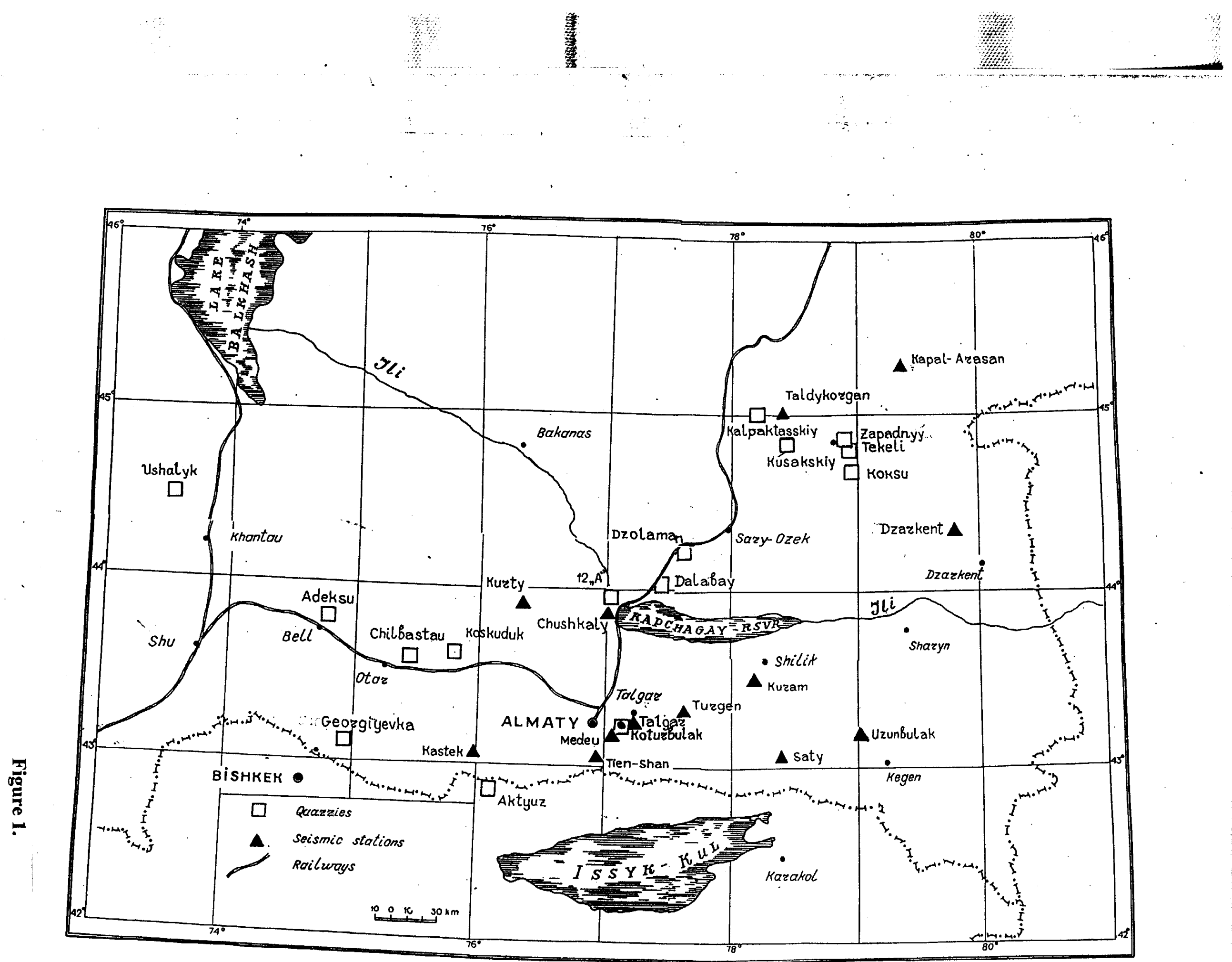


\section{EKIBASTUZ COAL BASSIN \\ The plan}

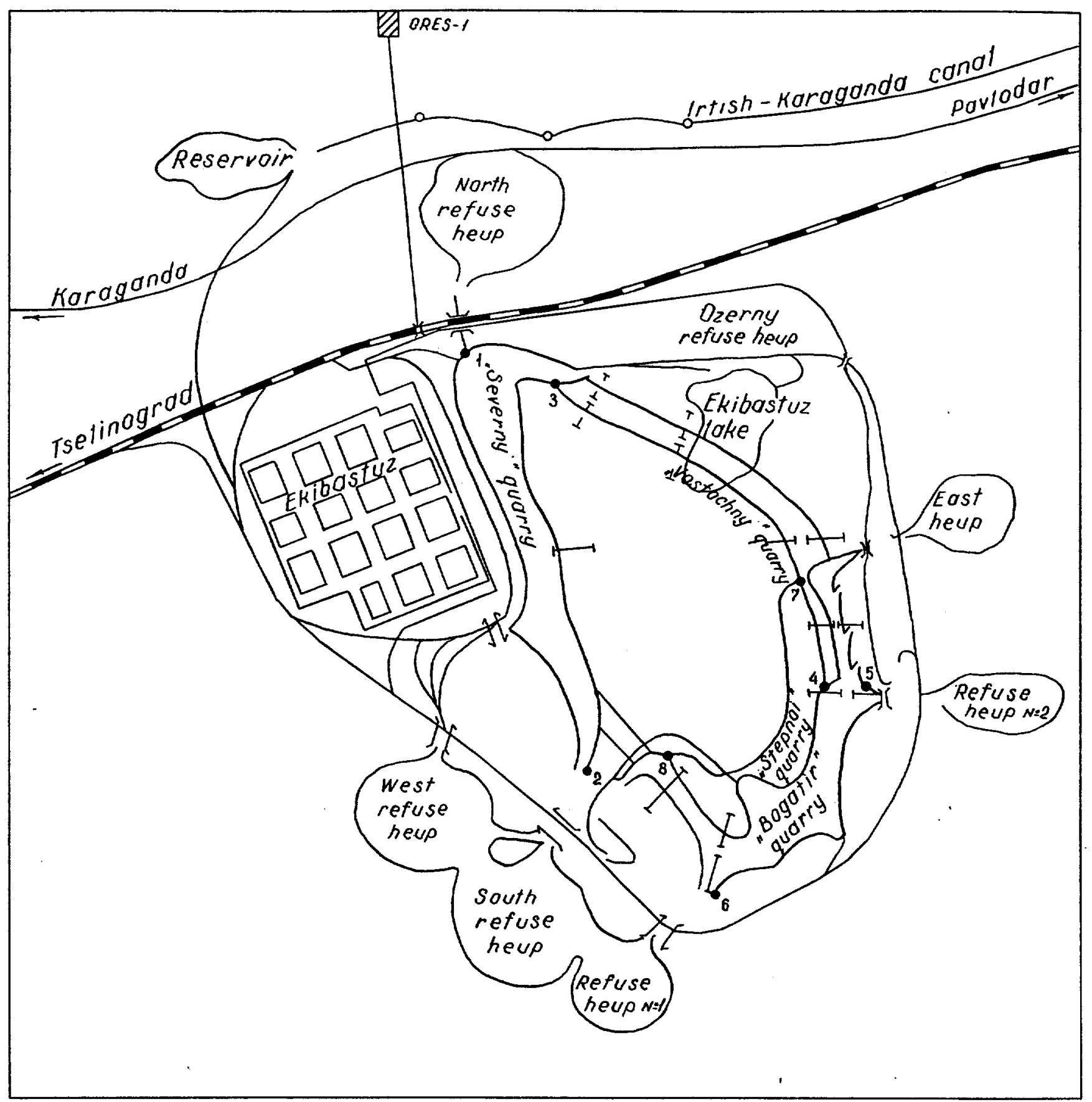

Coordinates of the points shown on the plan as number

\begin{tabular}{|c|c|c|c|c|c|}
\hline №oㅡ & Latitude & Longitude & №№ & Latitude & Longitude \\
\hline 1 & $51^{\circ} 44^{\prime} 50^{\prime \prime}$ & $75^{\circ} 21^{\prime} 30^{\prime \prime}$ & 5 & $51^{\circ} 41^{\prime} 05^{\prime \prime}:$ & $75^{\circ} 28^{\prime} 10^{\prime \prime}$ \\
\hline 2 & $51^{\circ} 39^{\prime} 35^{\prime \prime}$ & $75^{\circ} 23^{\prime} 00^{\prime \prime}$ & 6 & $51^{\circ} 38^{\prime} 00^{\prime \prime}$ & $75^{\circ} 25^{\prime} 30^{\prime \prime}$ \\
\hline 3 & $51^{\circ} 44^{\prime} 10^{\prime \prime}$ & $75^{\circ} 22^{\prime} 30^{\prime \prime}$ & 7 & $51^{\circ} 41^{\prime} 10^{\prime \prime}$ & $75^{\circ} 27^{\prime} 20^{\prime \prime}$ \\
\hline 4 & $51^{\circ} 40^{\prime} 40^{\prime \prime}$ & $75^{\circ} 27^{\prime} 20^{\prime \prime}$ & 8 & $51^{\circ} 39^{\prime} 15^{\prime \prime}$ & $75^{\circ} 24^{\prime} 45^{\prime \prime}$ \\
\hline
\end{tabular}

Figure 2. 



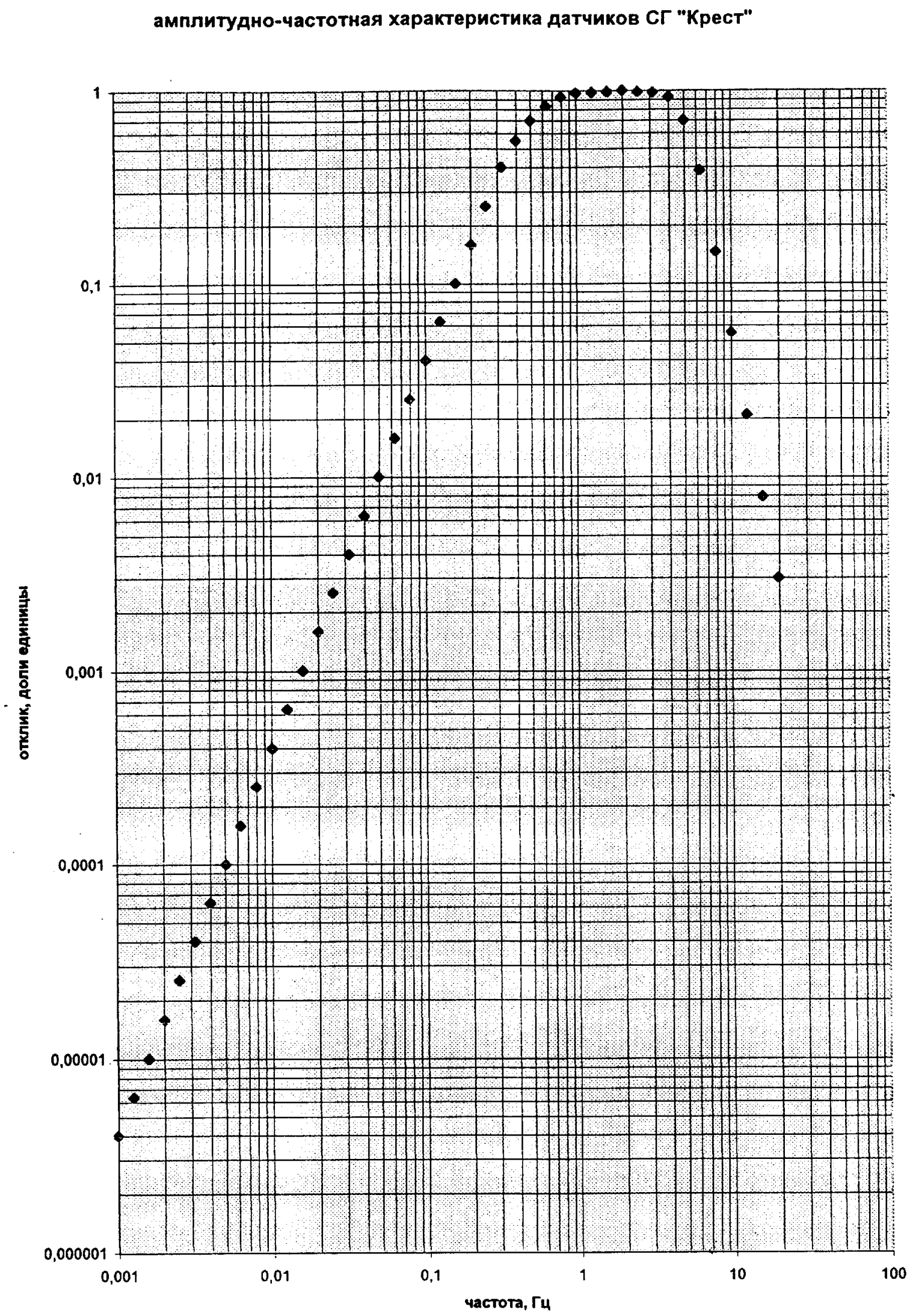

Figure 4. 


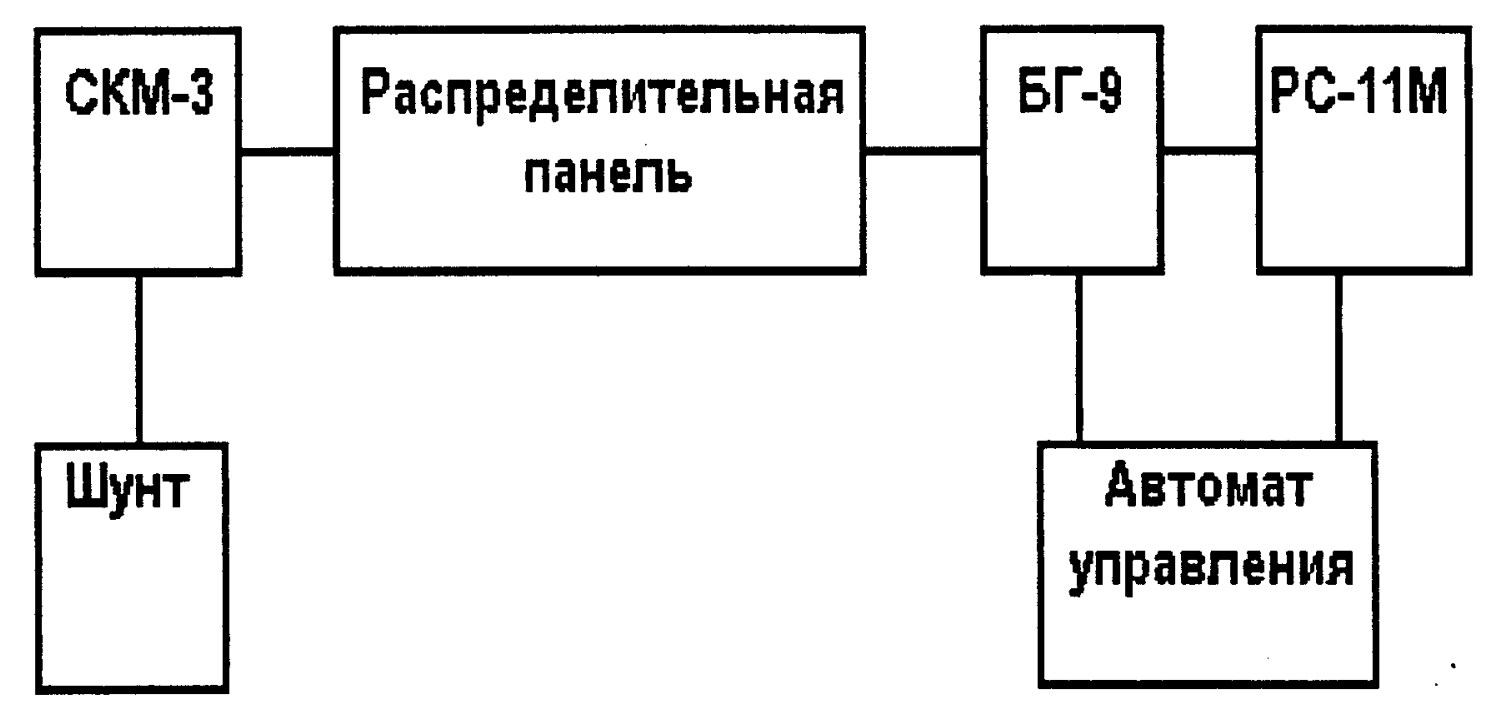

Figure 5. 


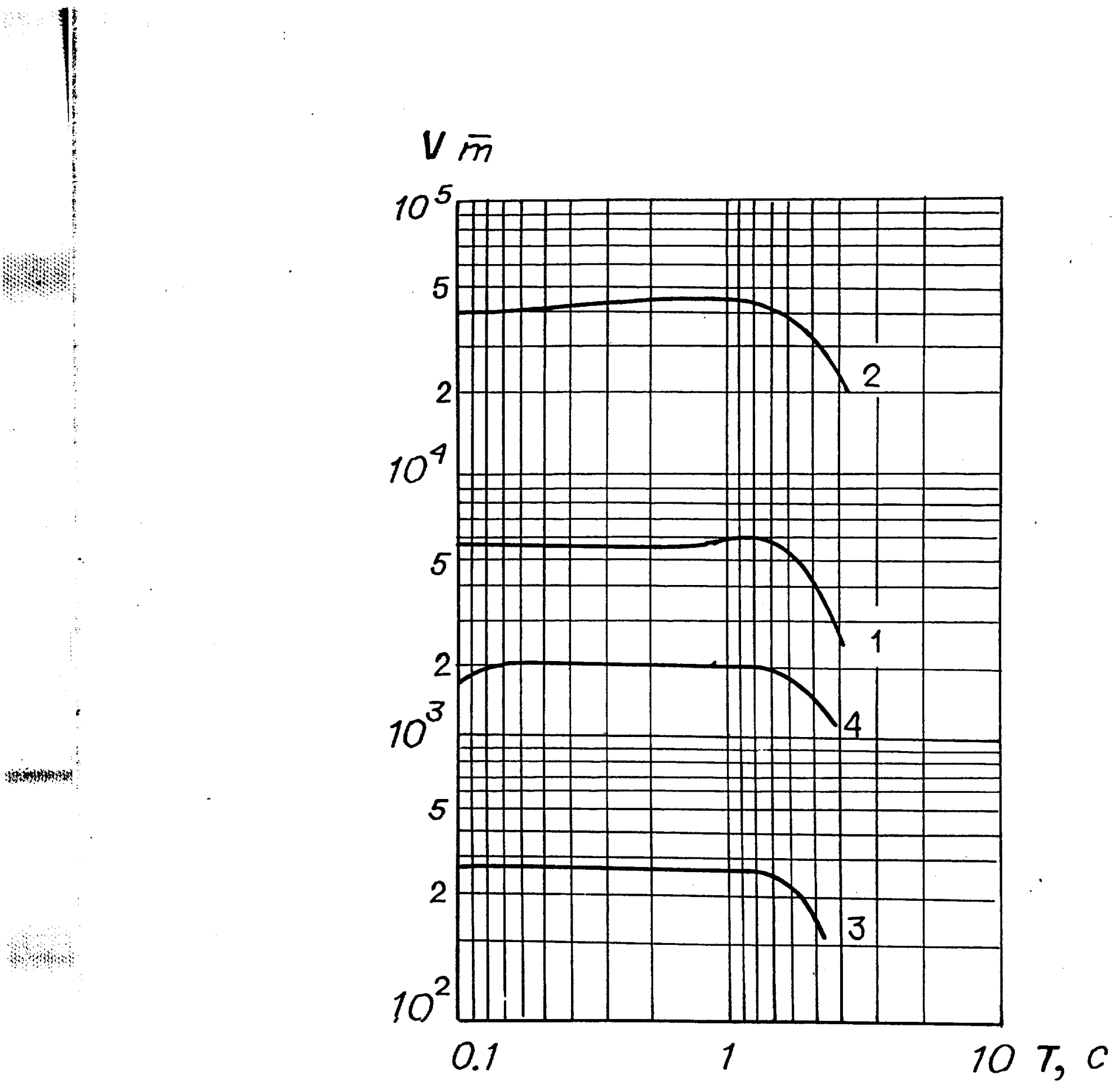

Figure 6. 

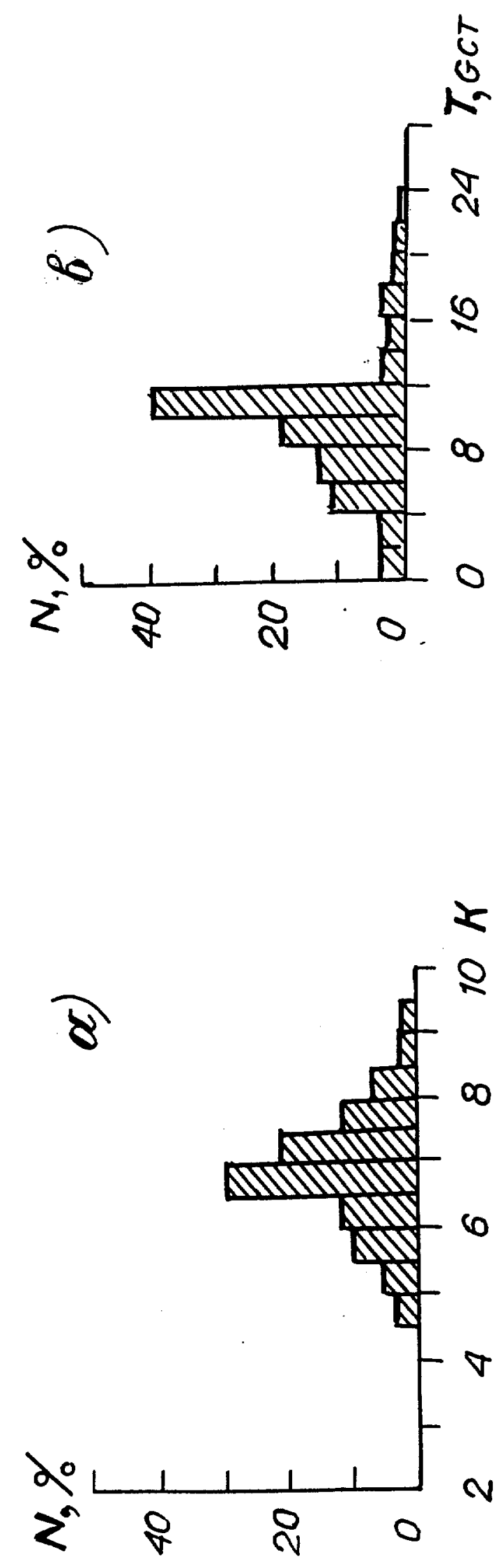

Figure 7. 


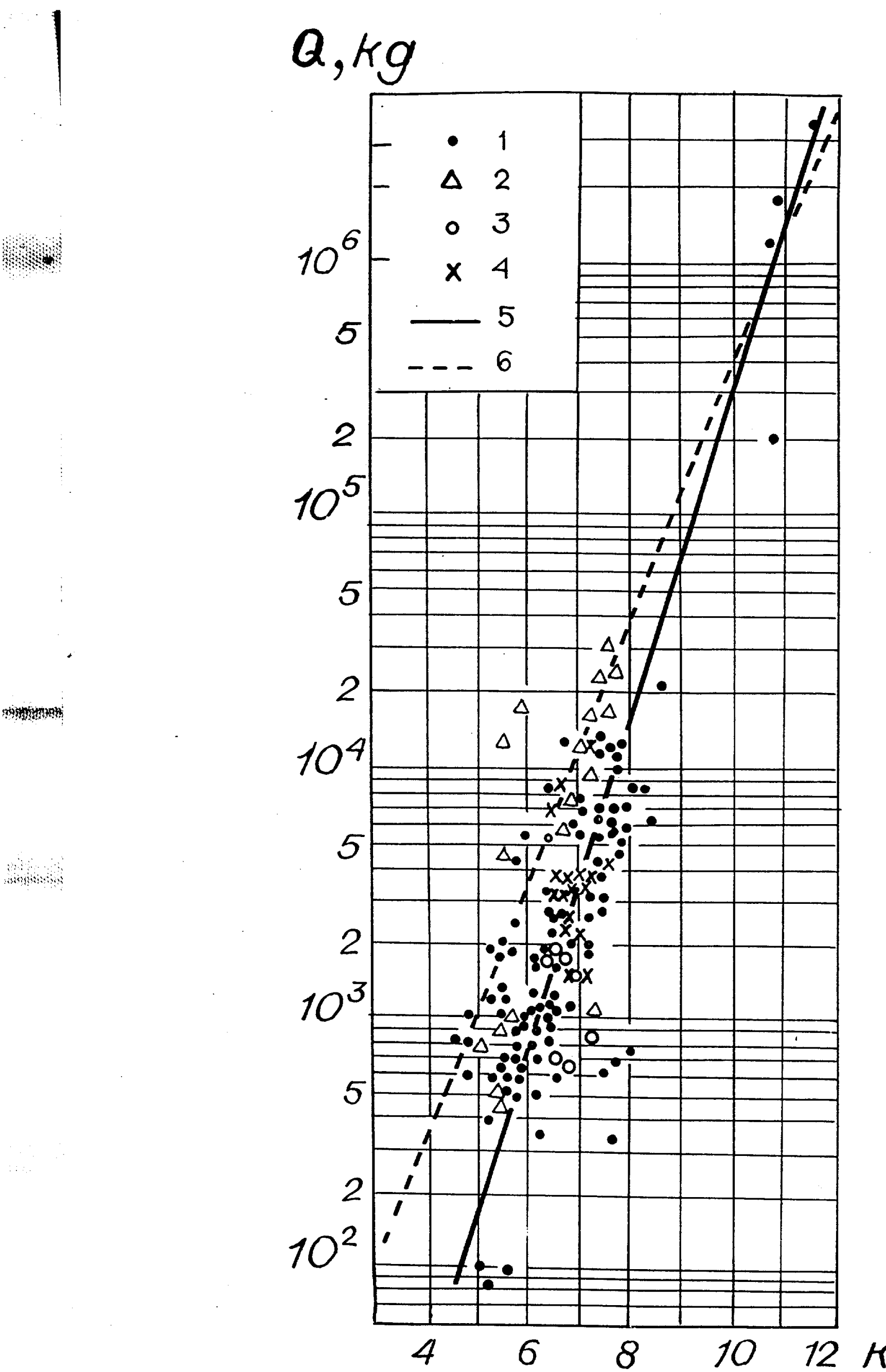

Figure 8. 


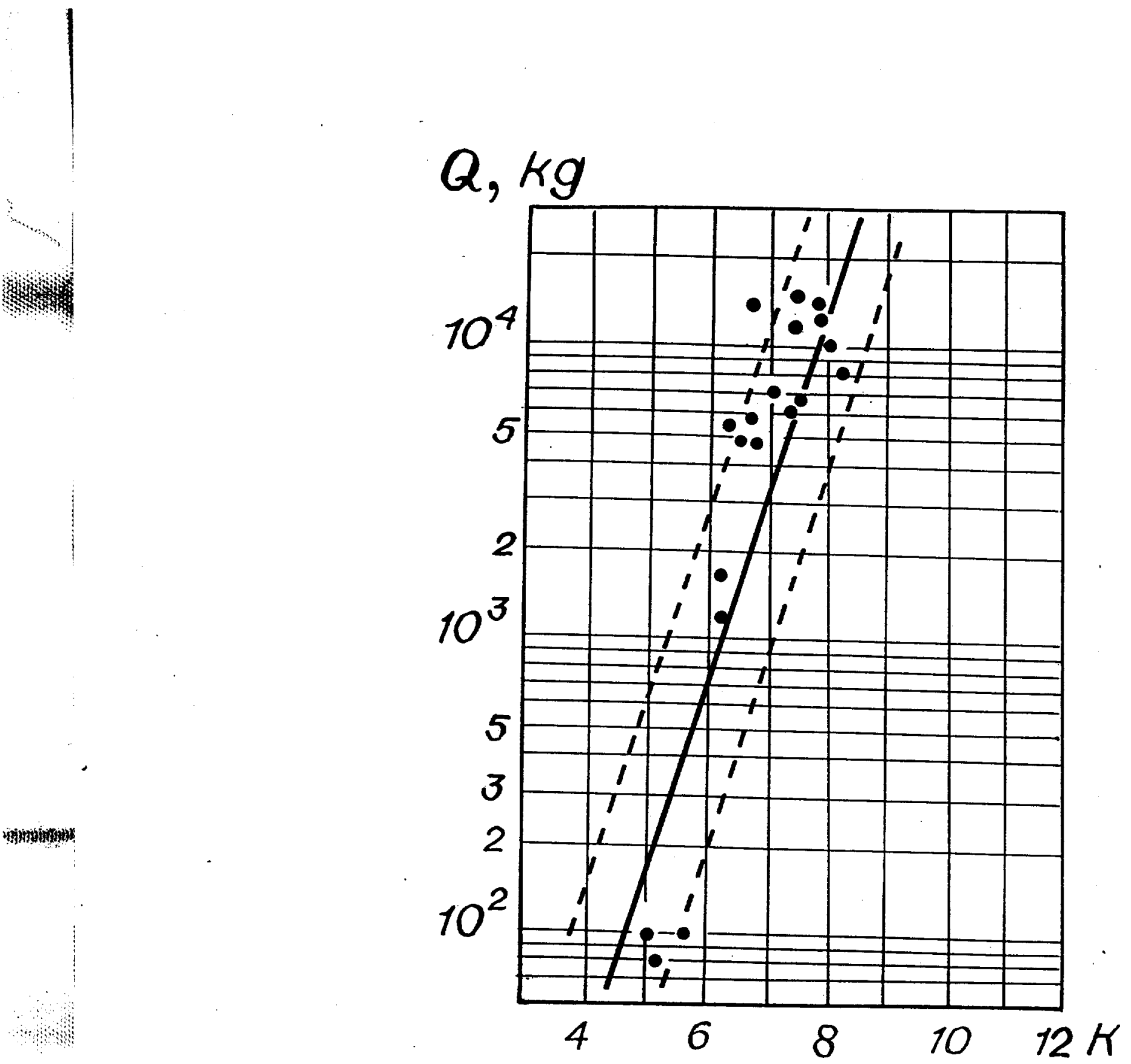

Figure 9. 


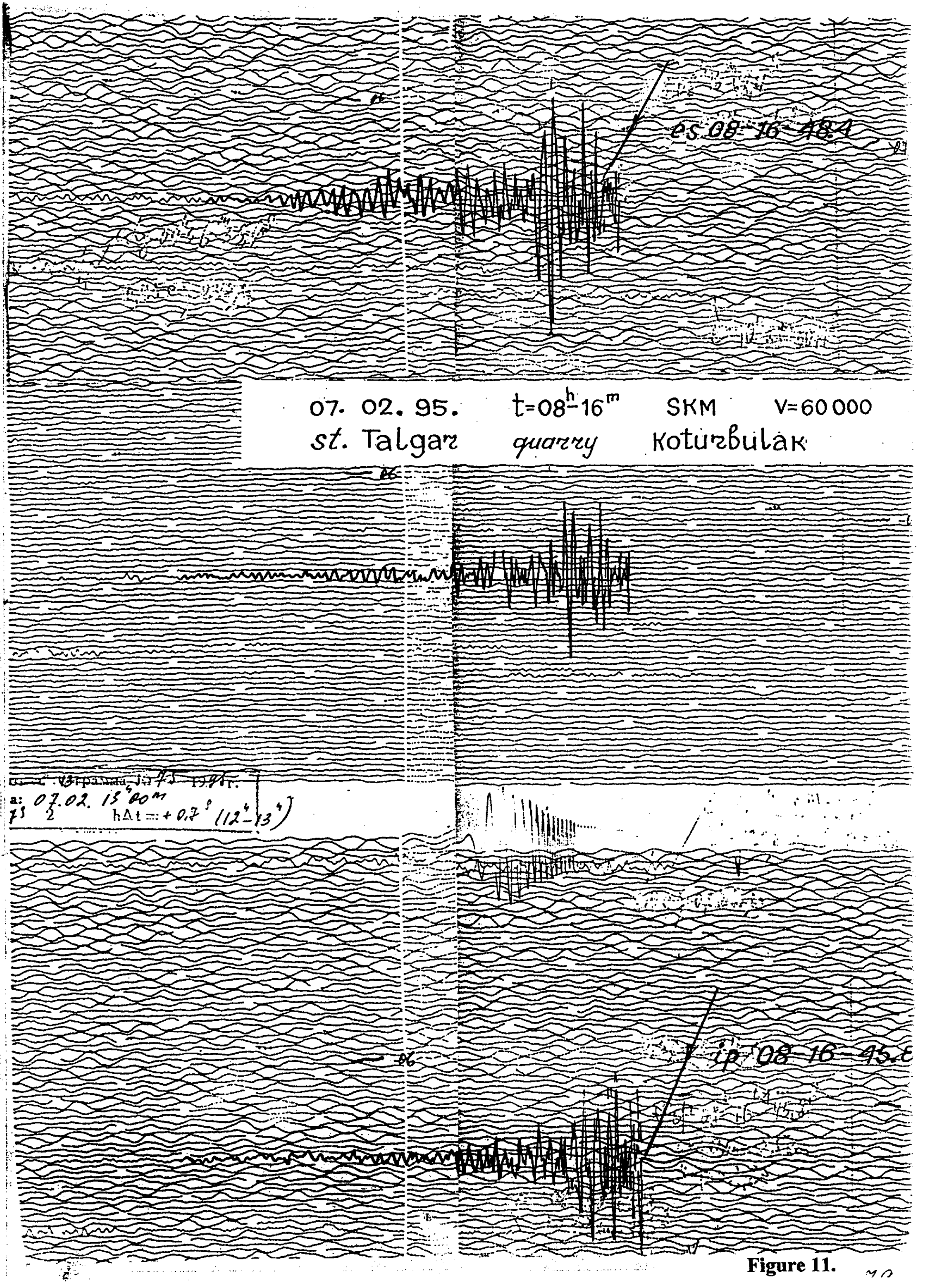




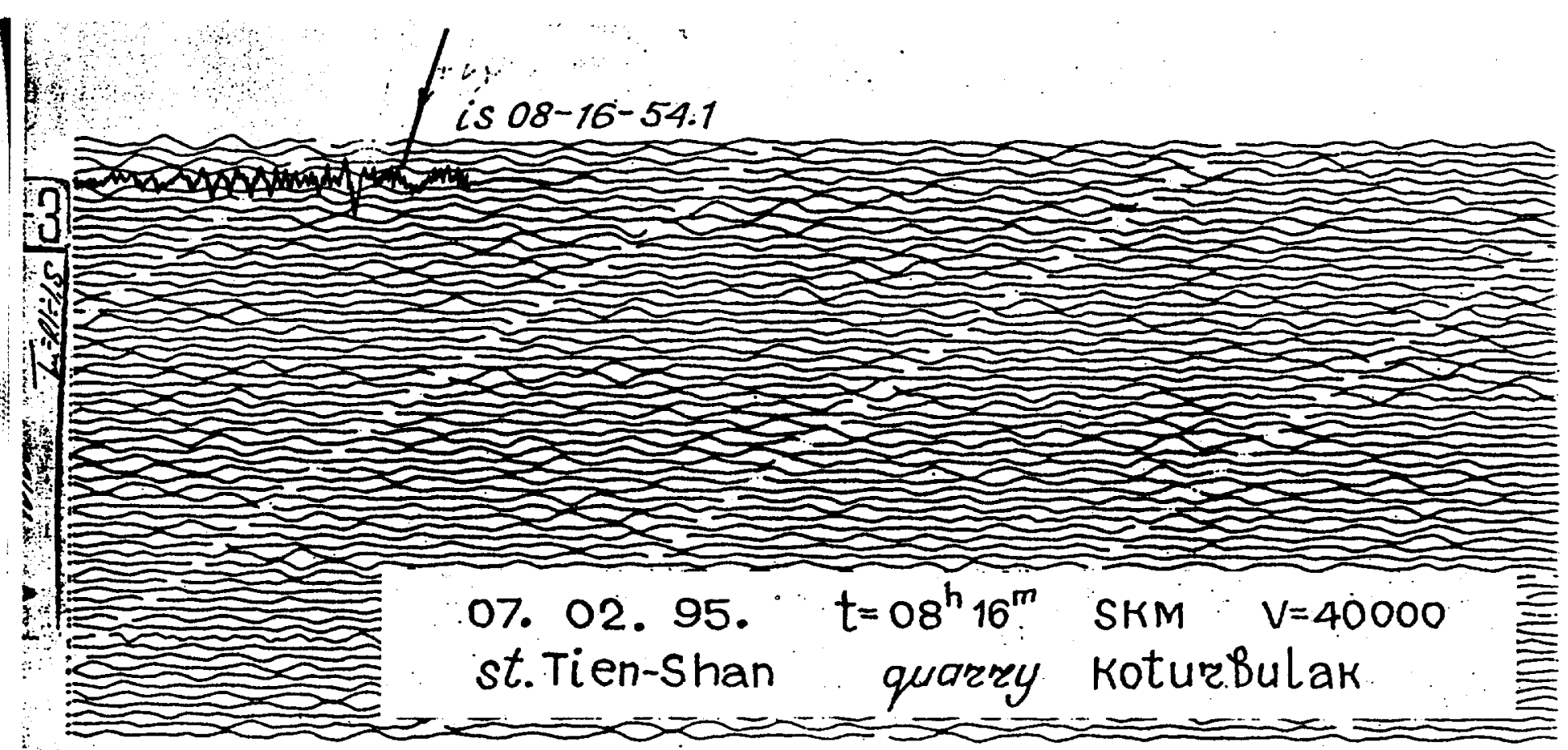

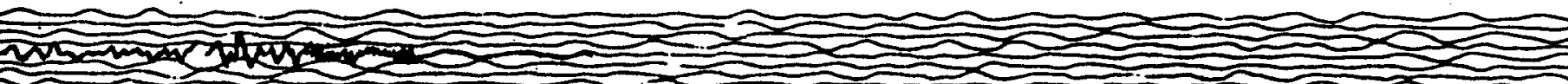
012

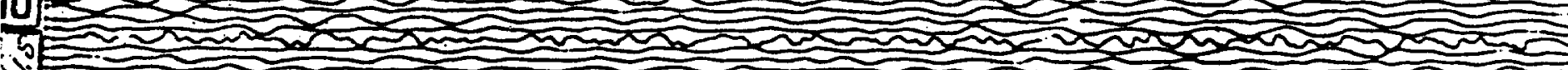

i.

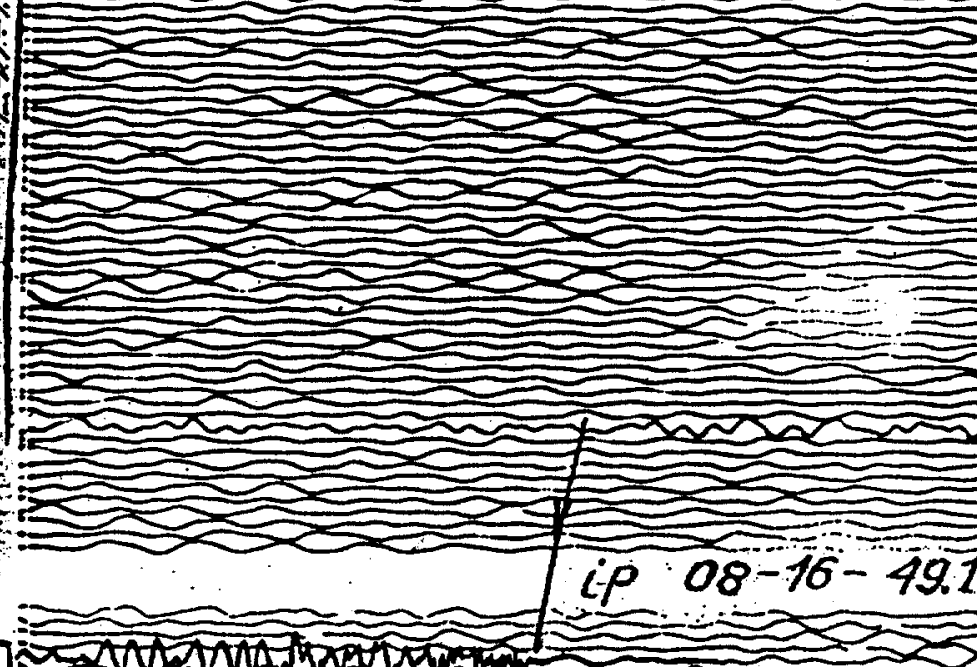
传

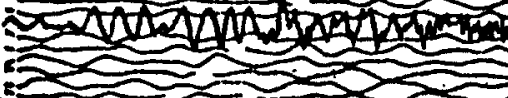
(4)

(n) Now 


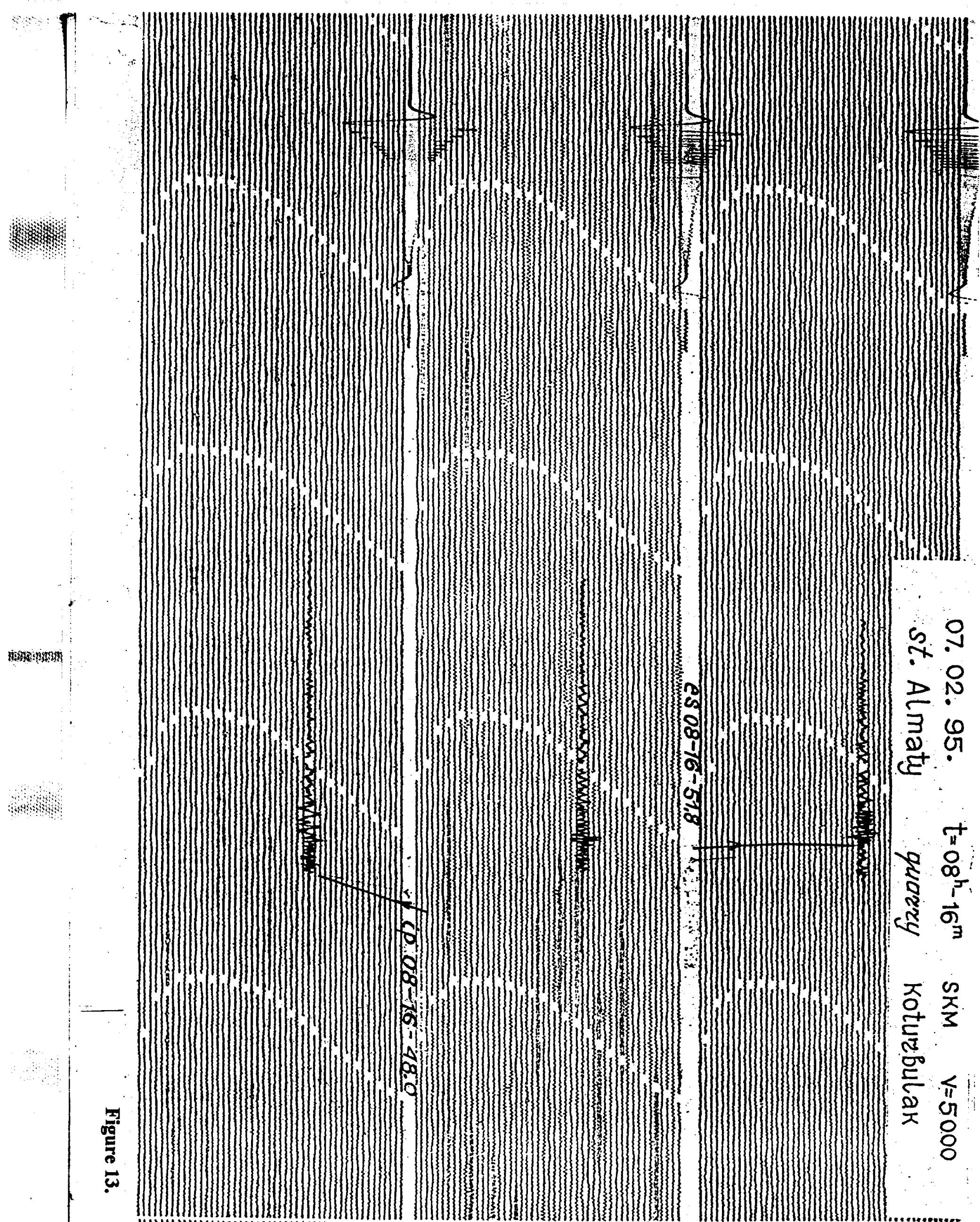


23,2023

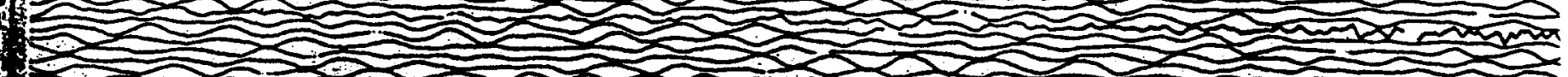

20 32



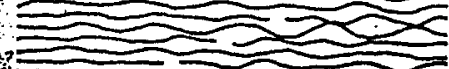

(n)

\subsection{2 .95$. \\ $t=08^{h}-16^{m}$ \\ SKM \\ $V=40000$ \\ st. Medeu \\ quarey Kotumbular}

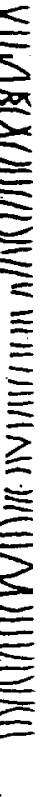

(n)

(n)

(2)

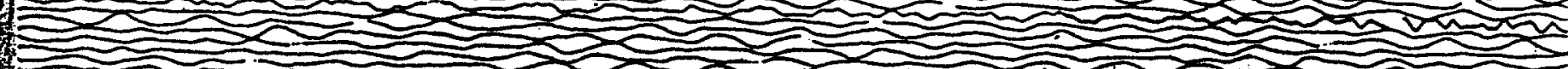
32

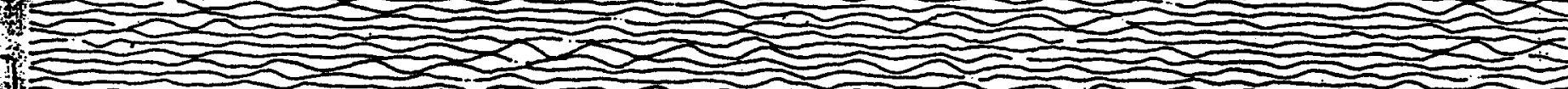

(n) i.

3

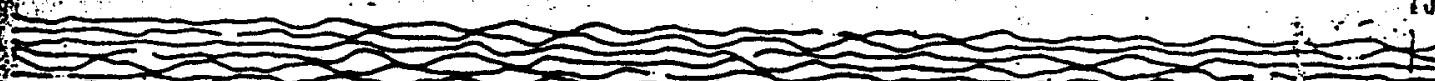

7

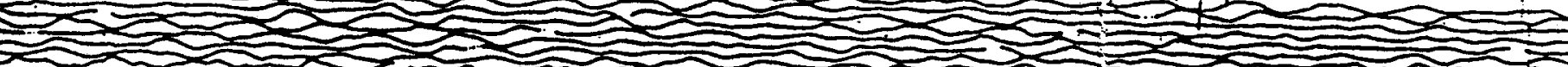

1

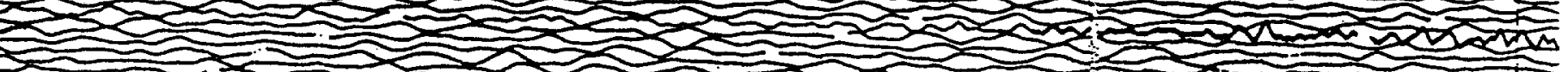
IS

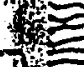

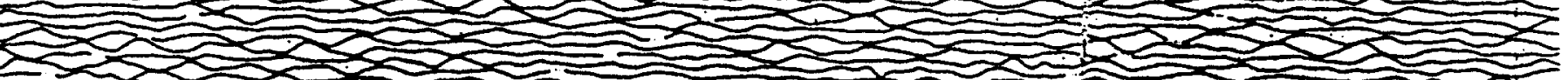

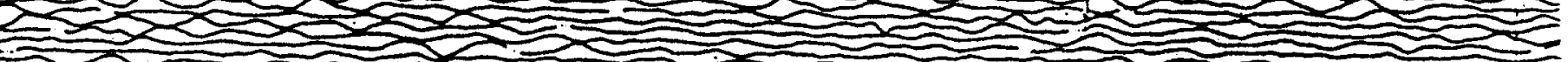

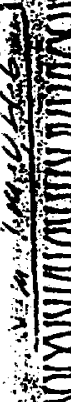

(n)

Figure 14. 


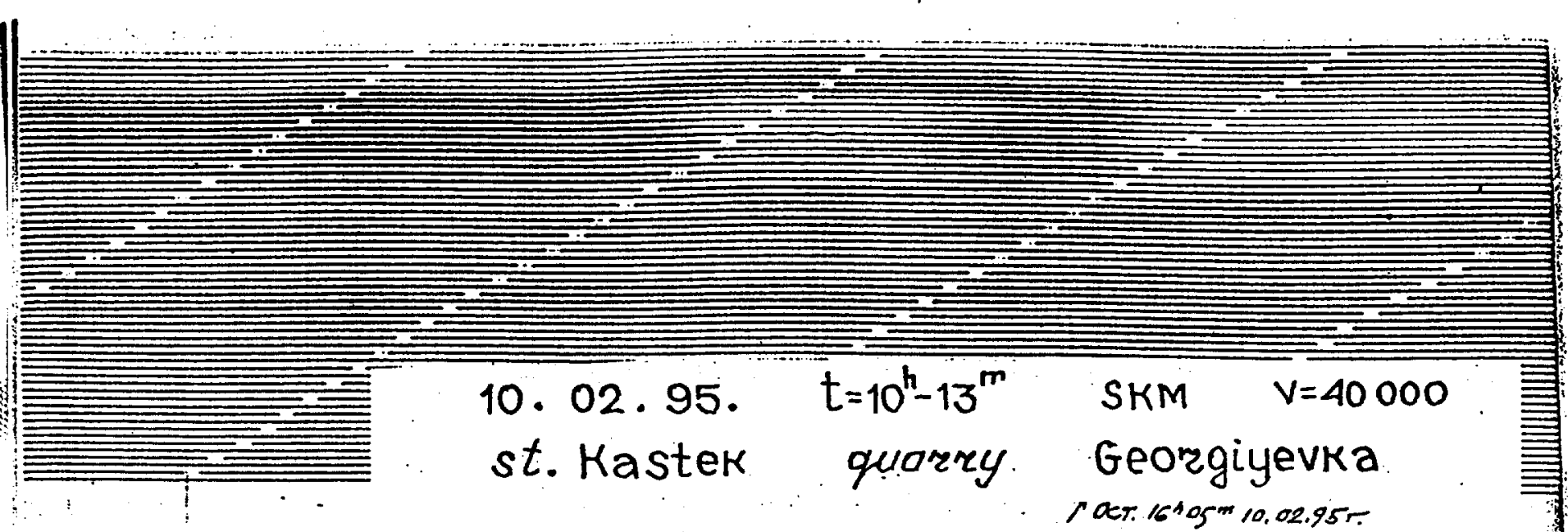

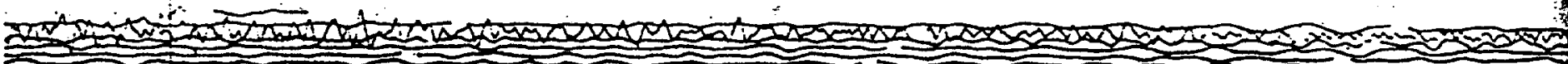
(n)

(1)

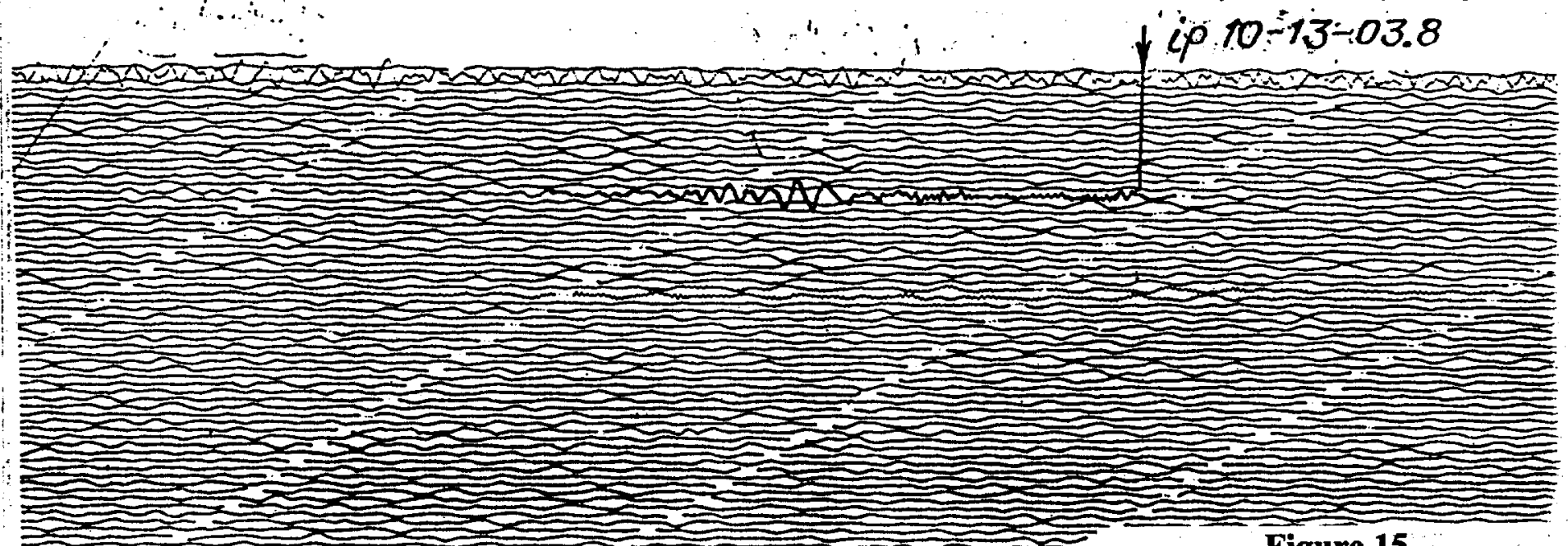




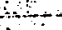

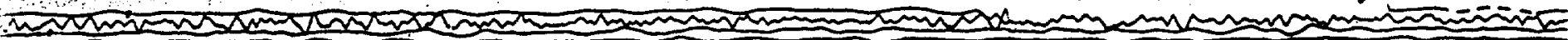

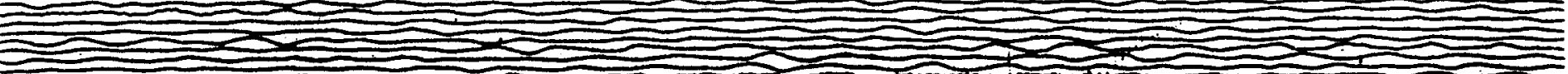
202020

$\longrightarrow 2$

2

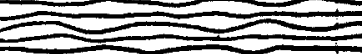

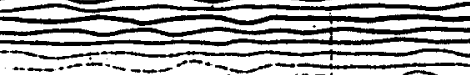

\section{02. 95. $t=10^{h}-13^{m}$ SikM $v=40000$ \\ st. Kurty \\ quarry Georgiyeura}

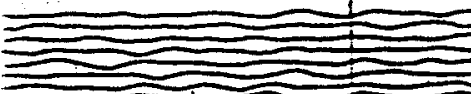

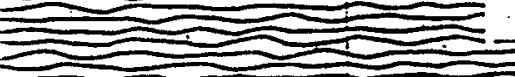

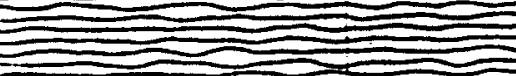

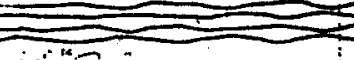

47

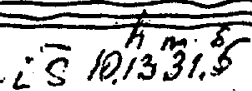

(1)

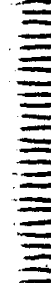

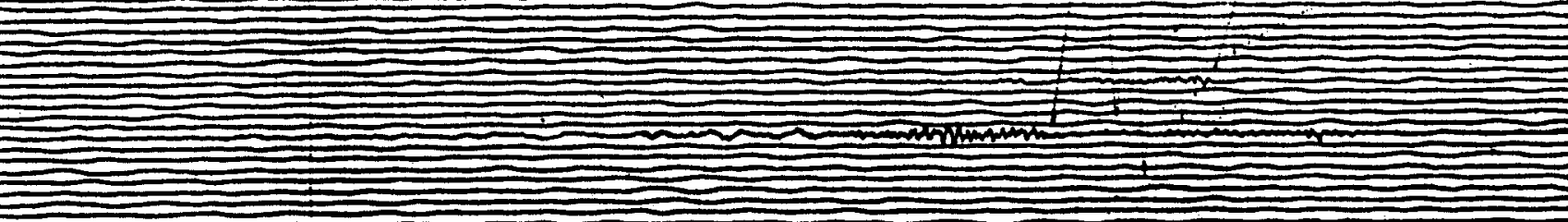

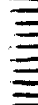

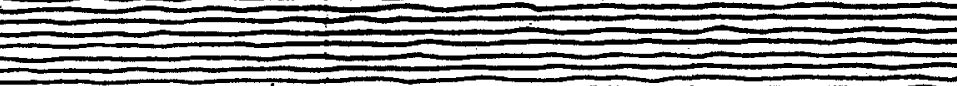

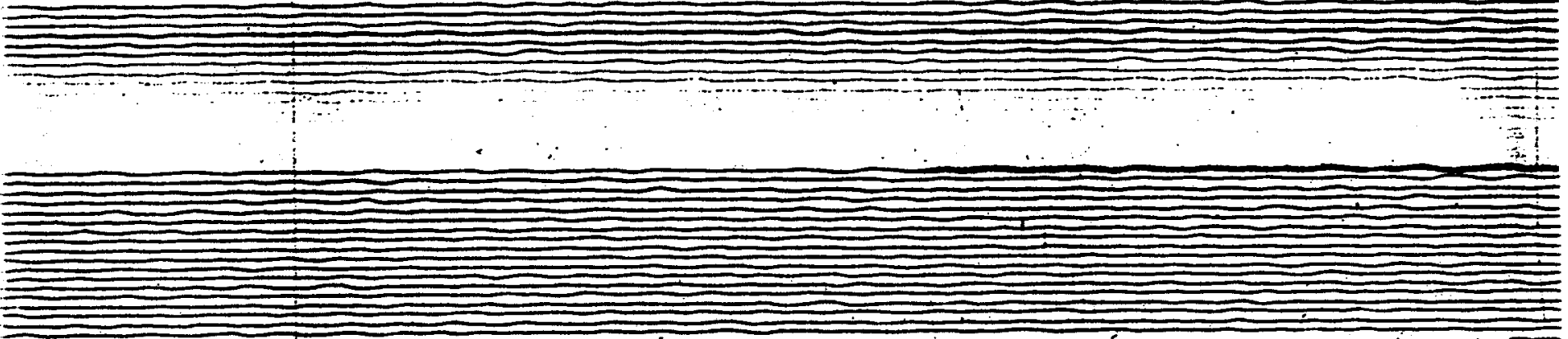

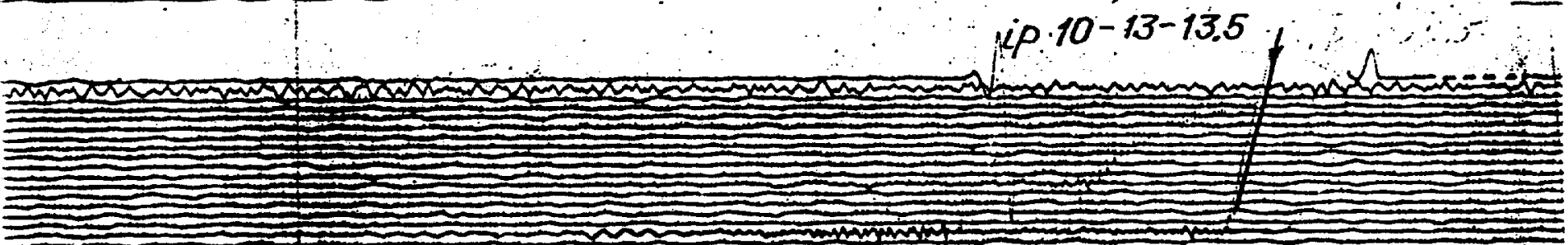

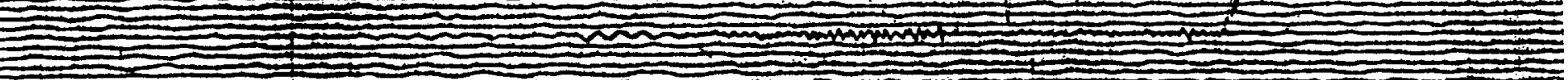
202 20120 (1)

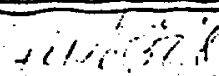




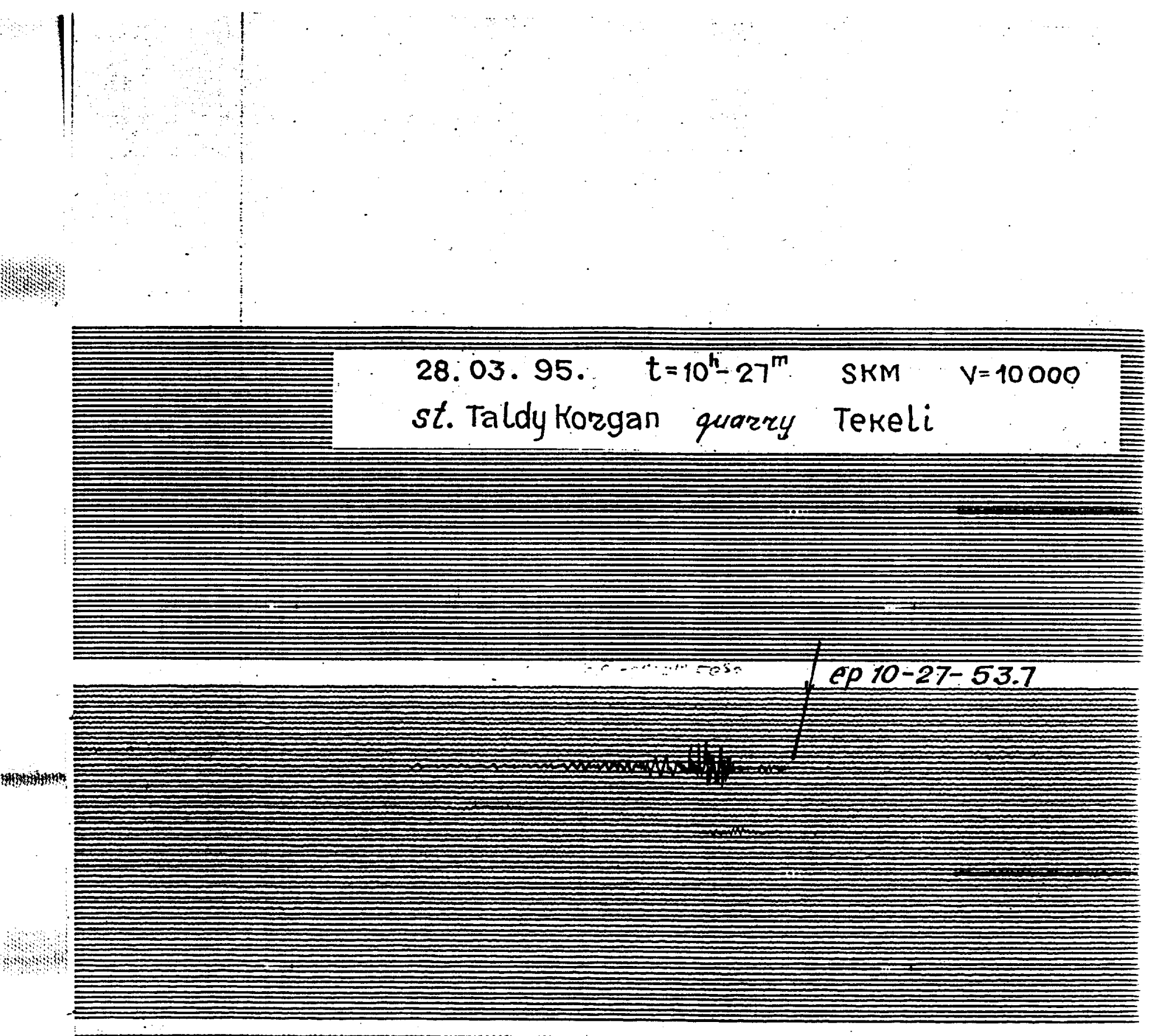




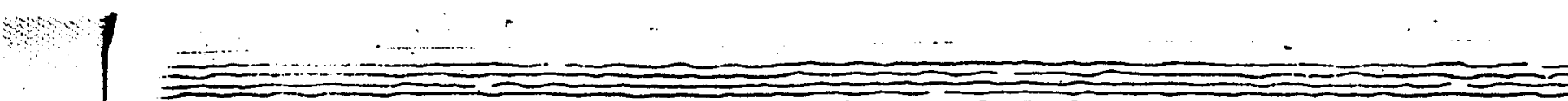

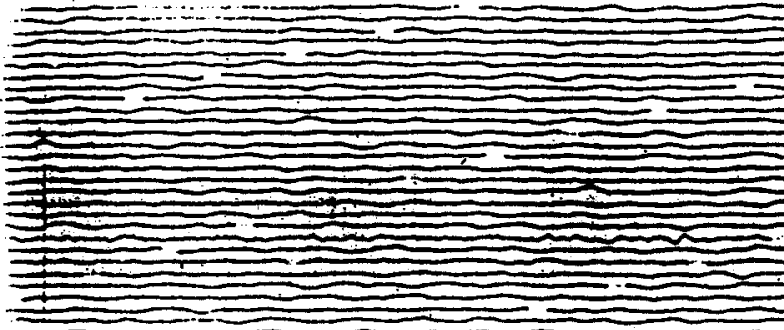

$$
\begin{aligned}
& \text { 17. O5. 95. } t=07^{h}-45^{m} \text { EKM } v=40000 \\
& \text { st. Kurty quarzy Dzolaman }
\end{aligned}
$$

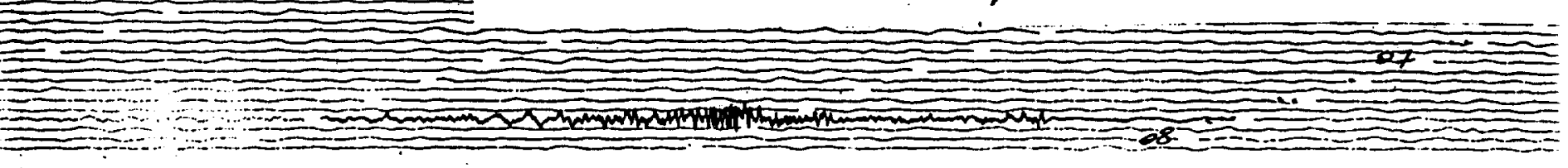
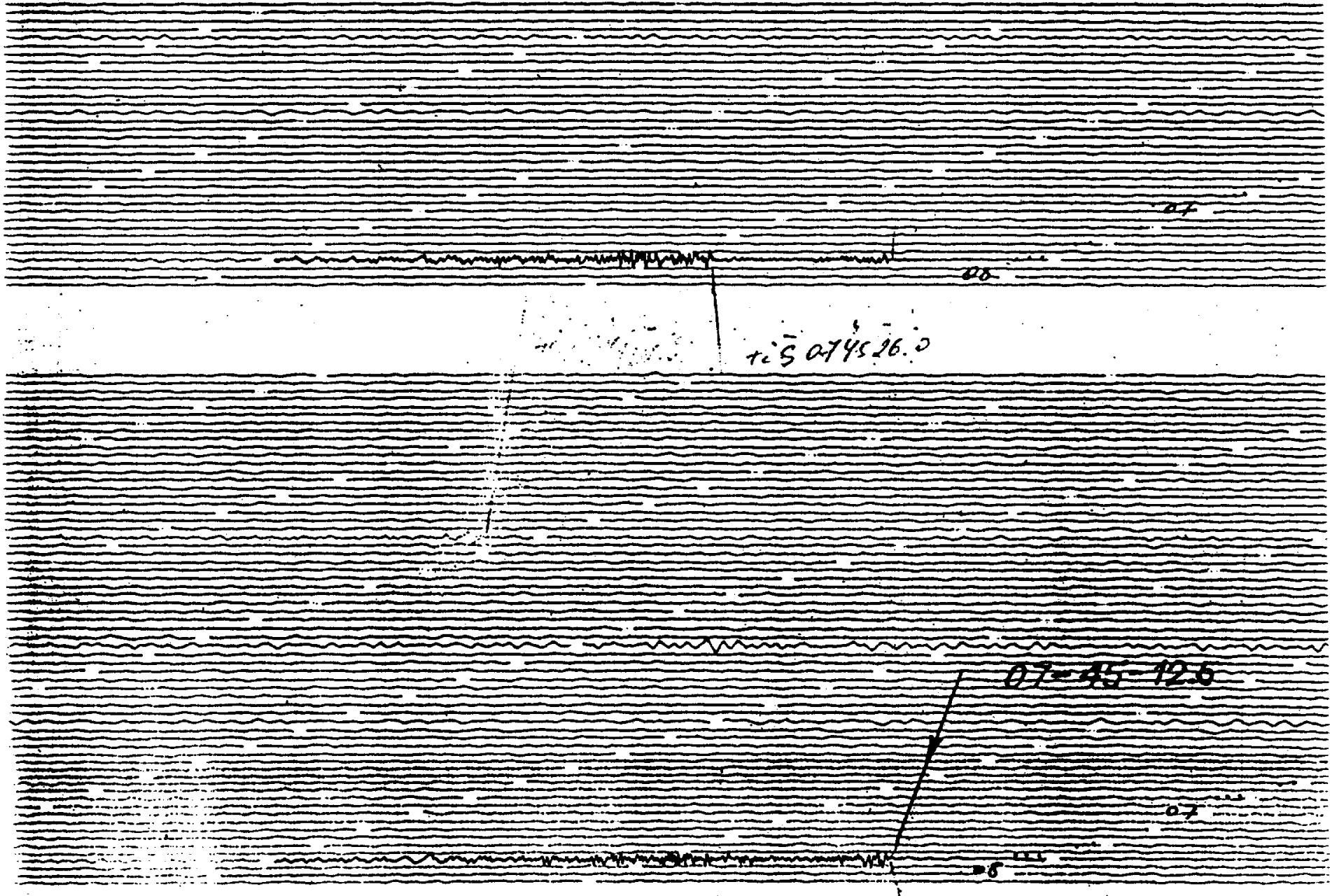


\section{05. 95. $t=07^{h}-45^{\mathrm{m}}$ SKM $v=40000$ st. Kastek quatry Dzolaman}

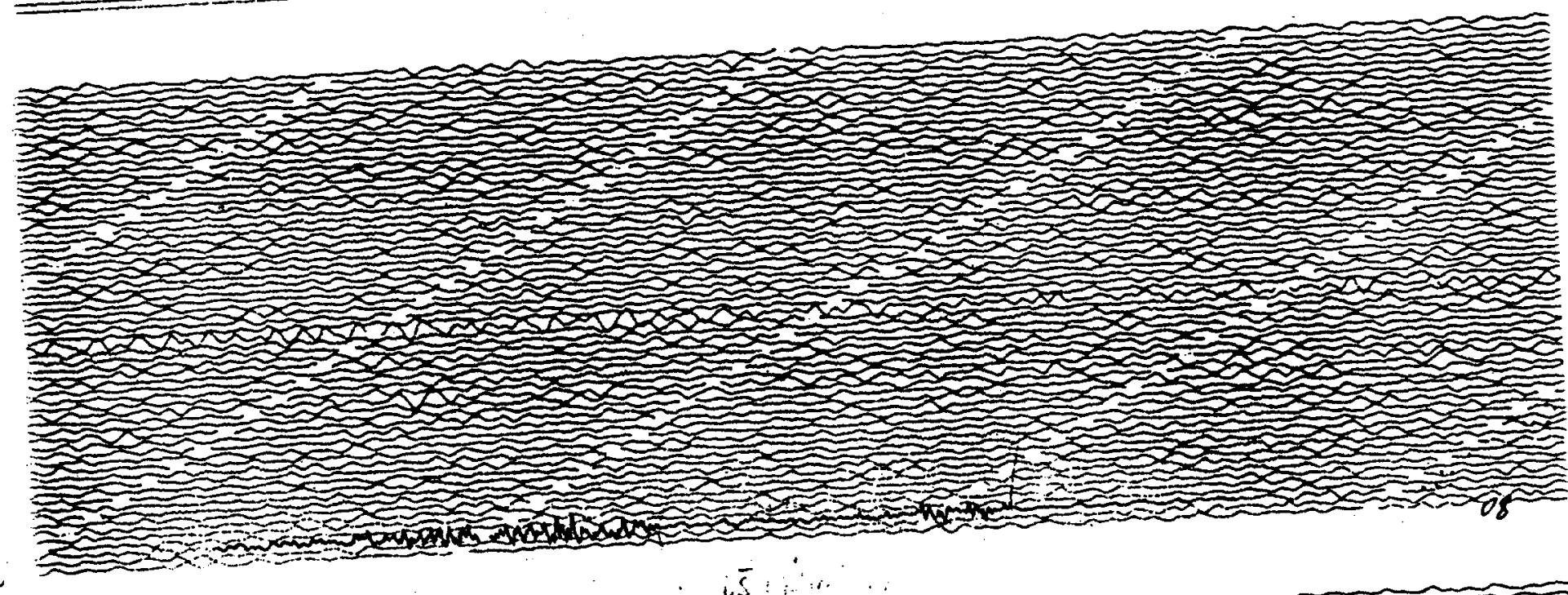

0,200

How (

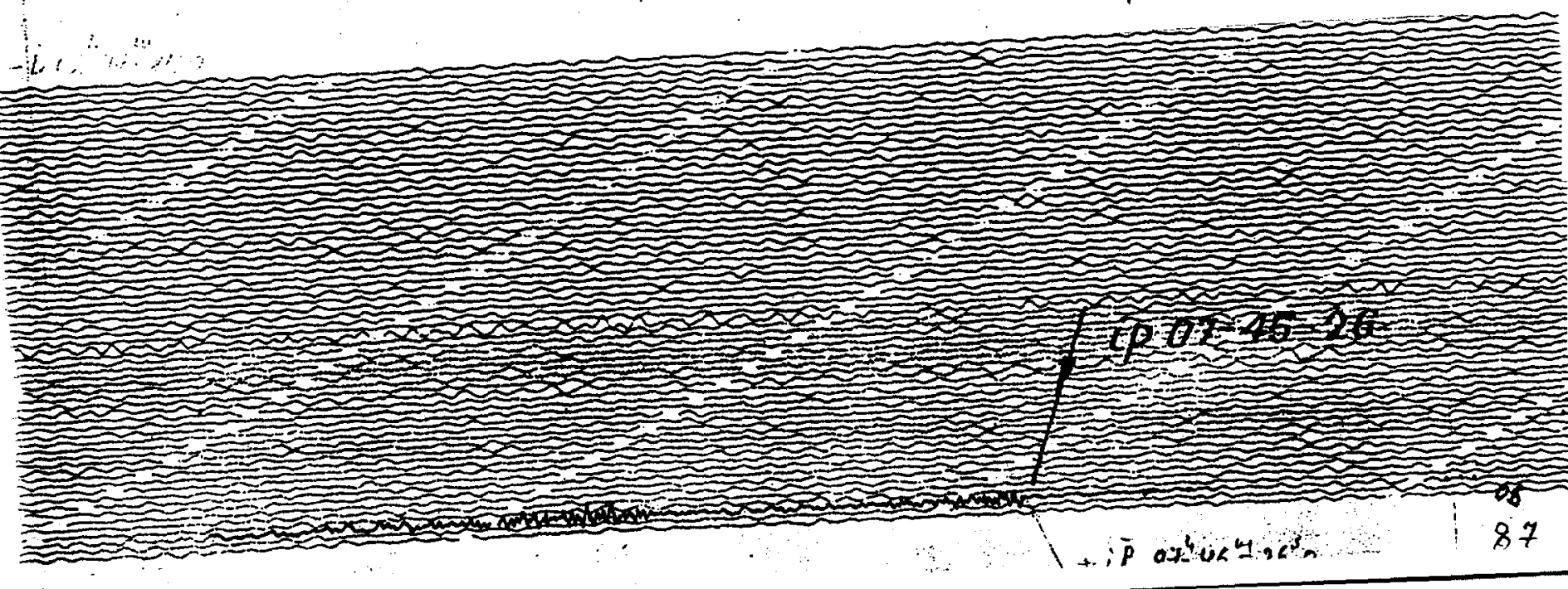




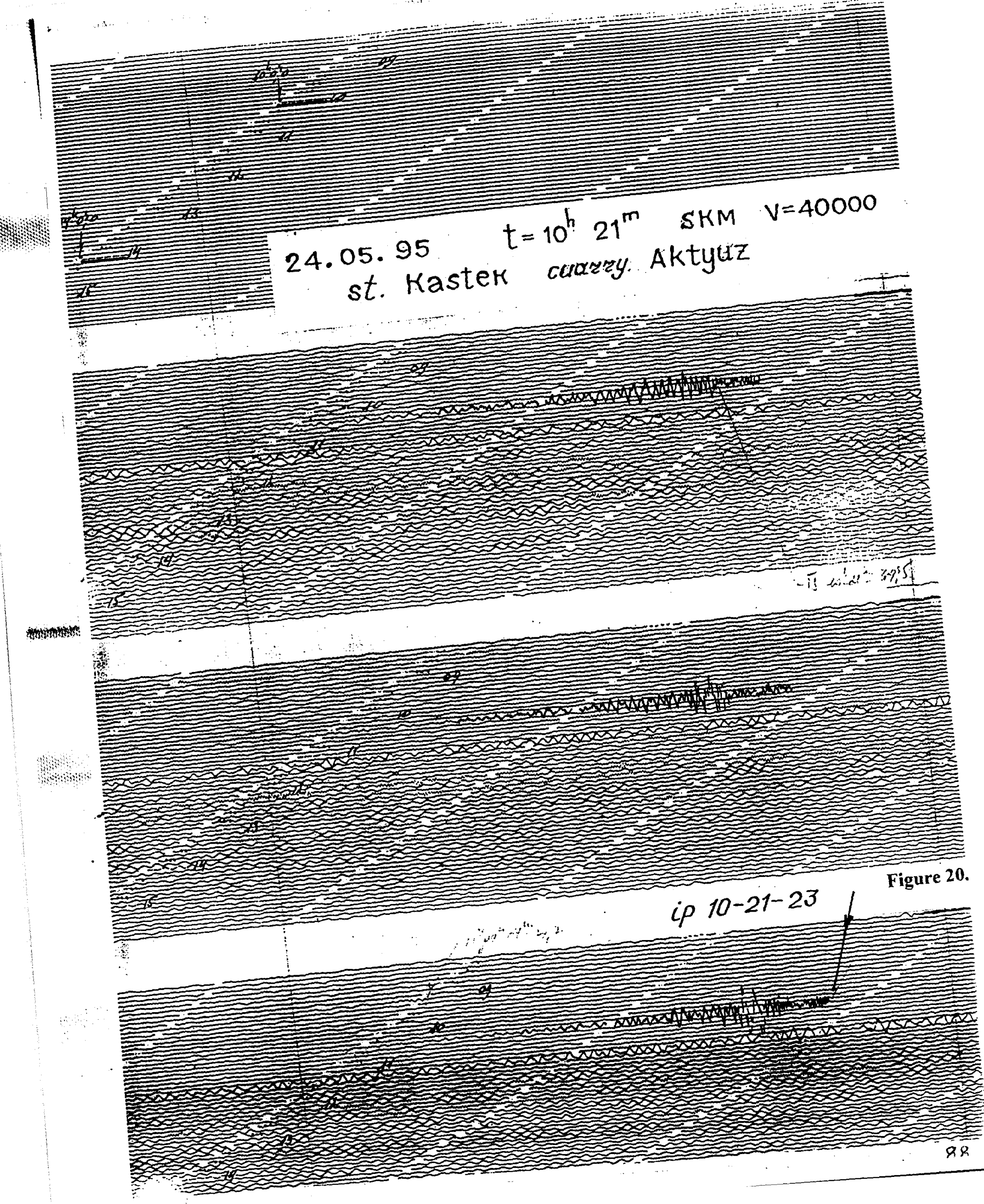




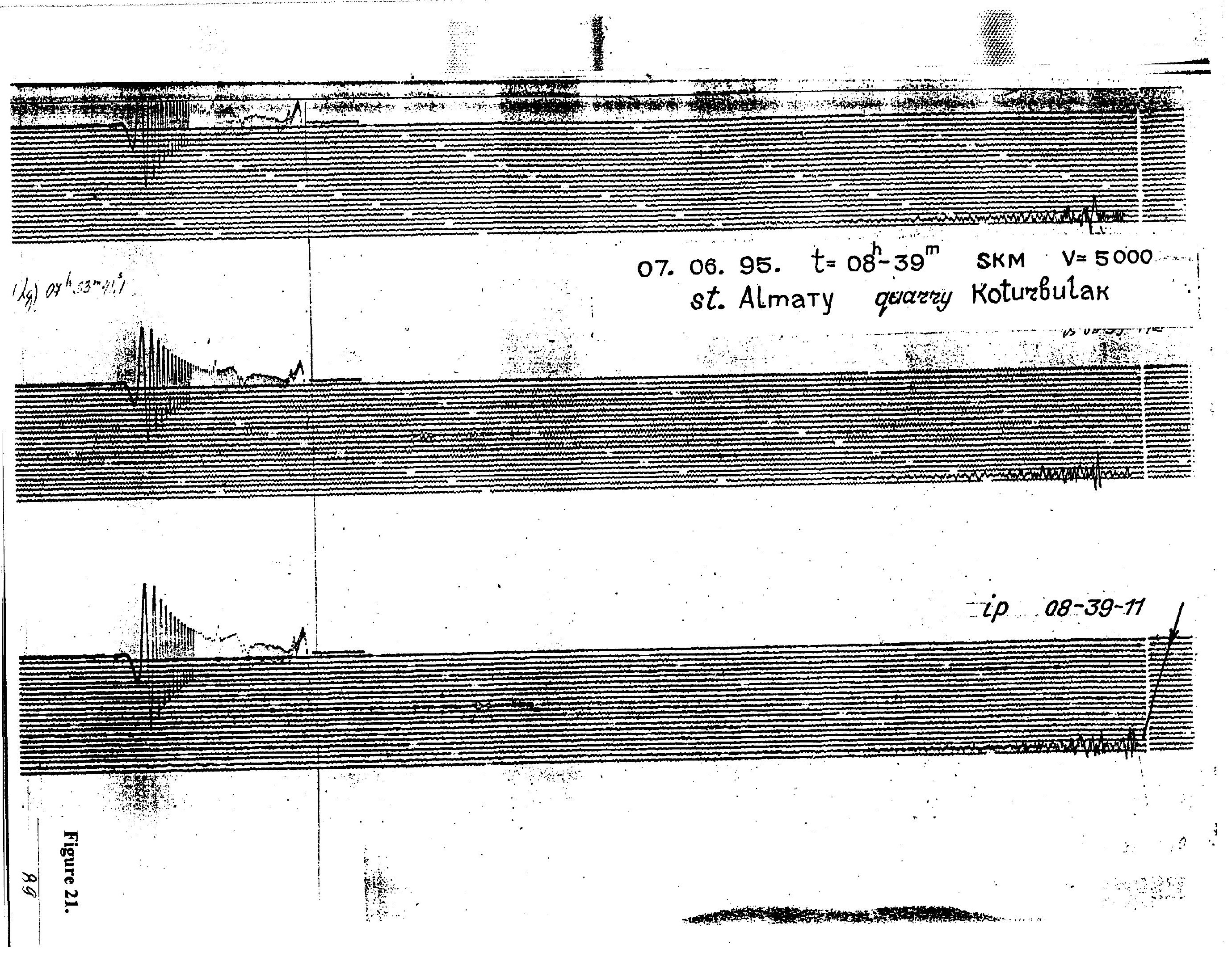




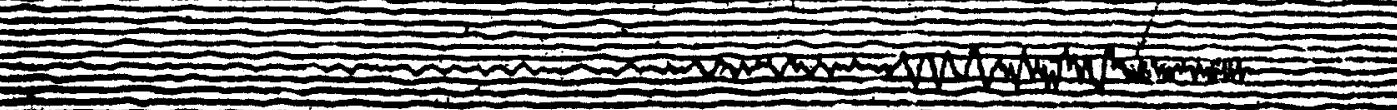

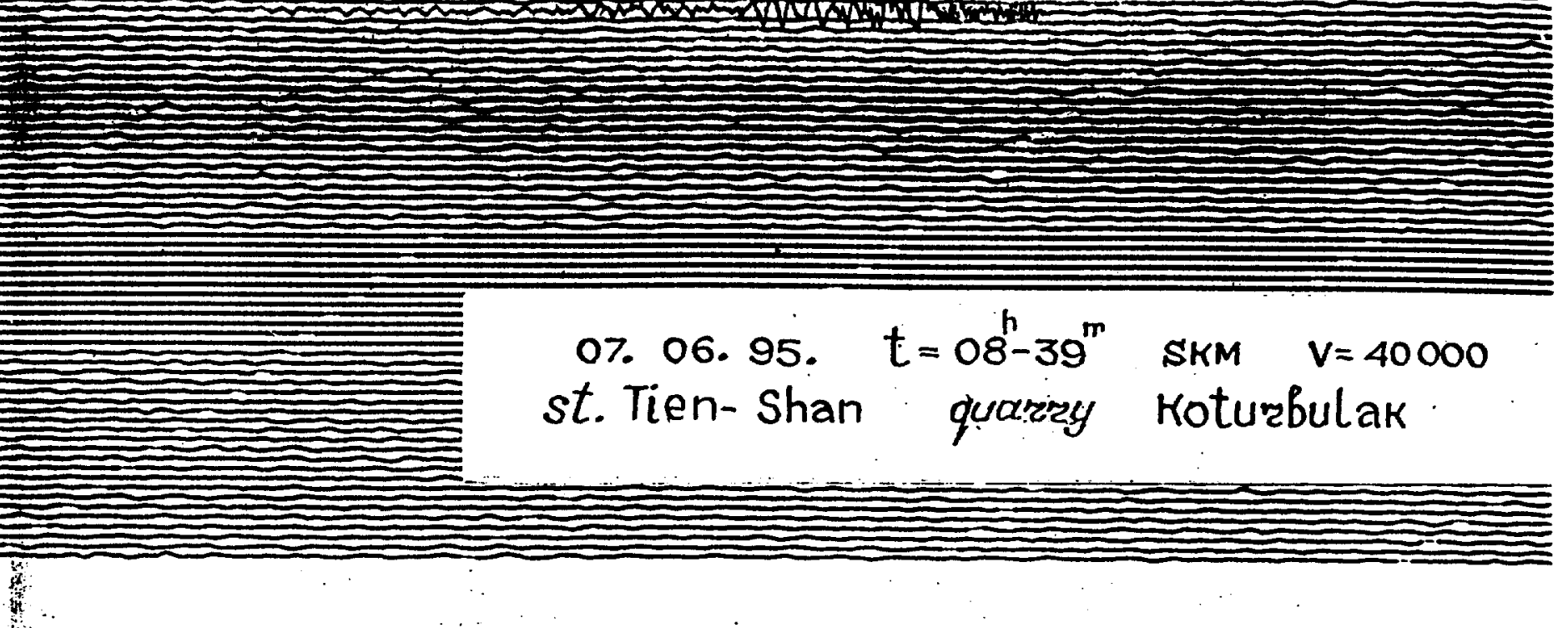

Hhom

三

wnw

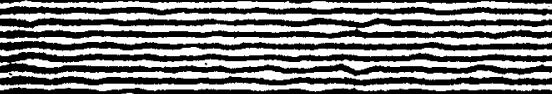

And

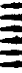

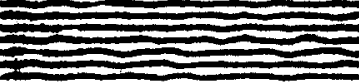




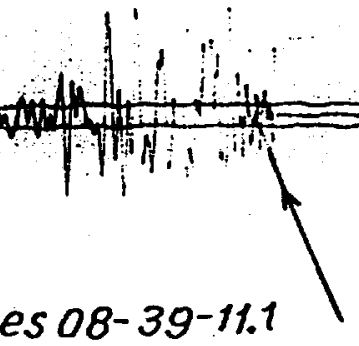

07. 06. 95. $t=08^{h}-39^{m}$ skM. $V=40000$ st. Medeu quaray Koturbulak
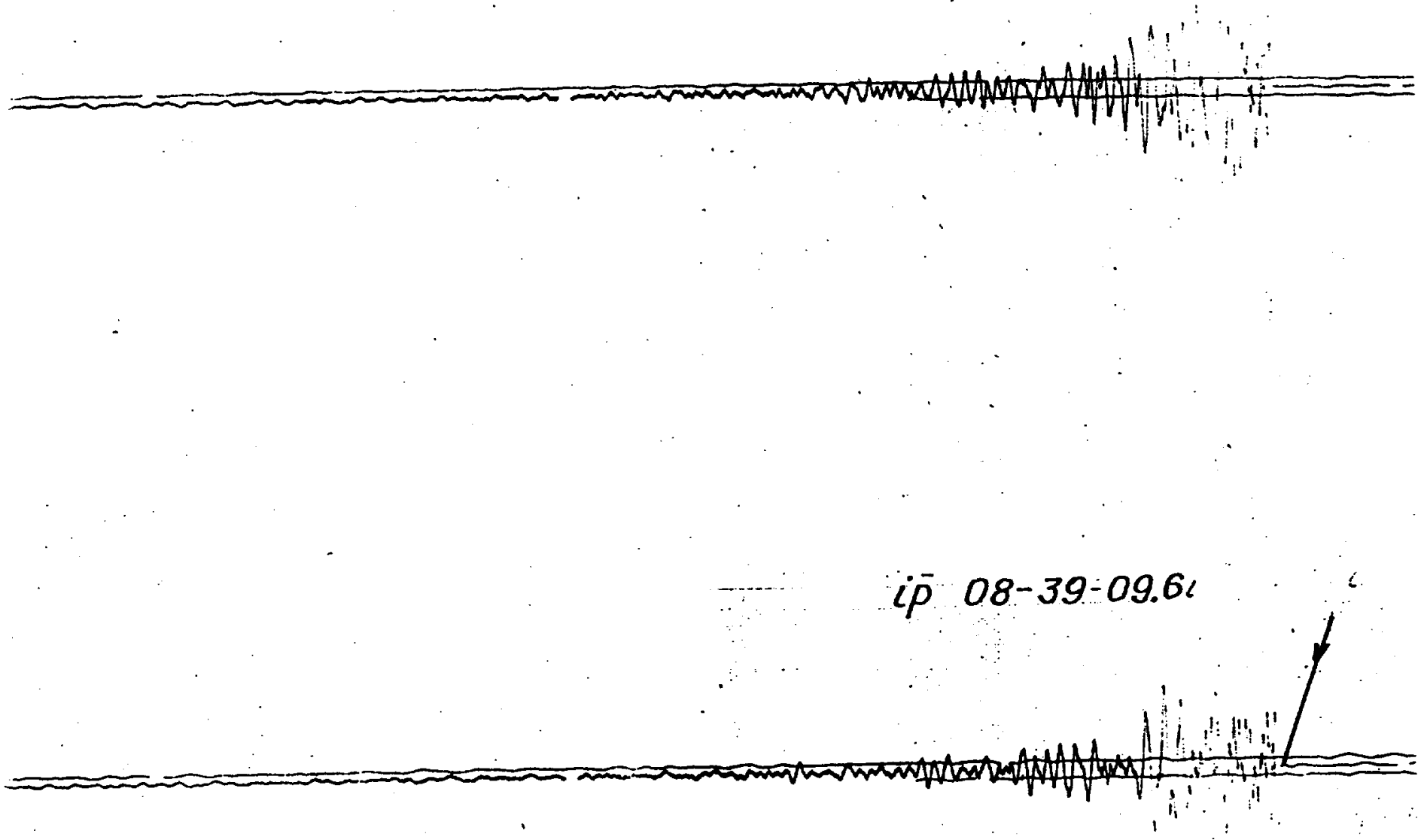

Figure 23. 


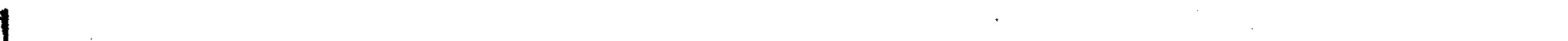

be
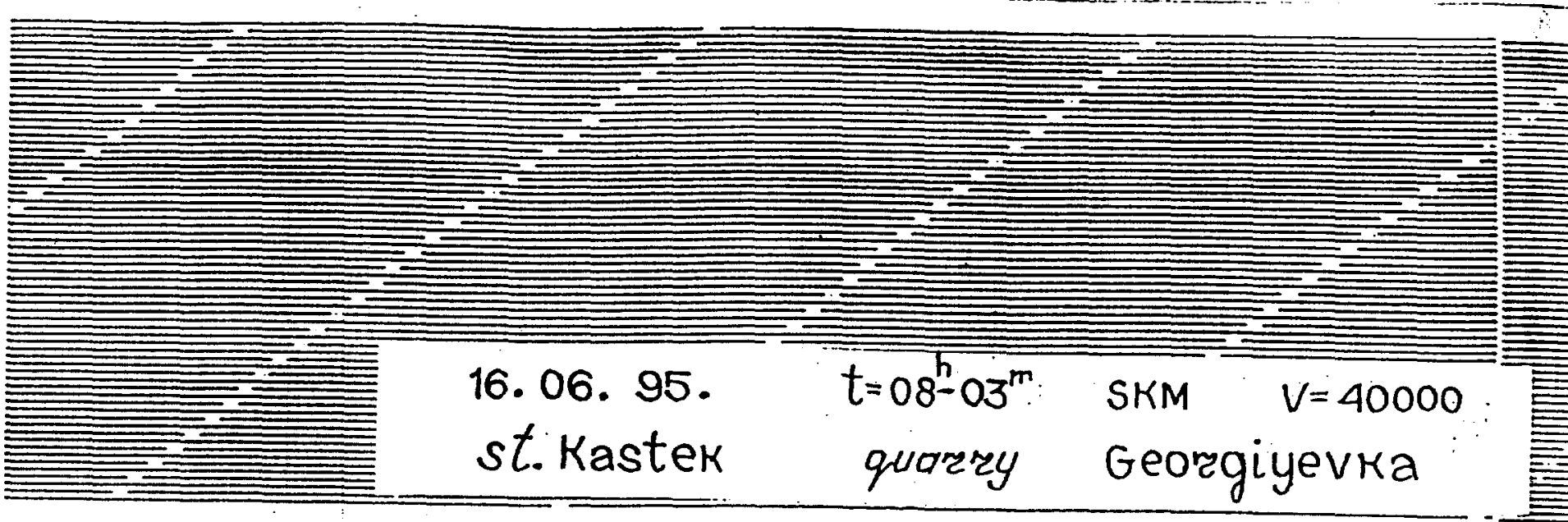

(2)
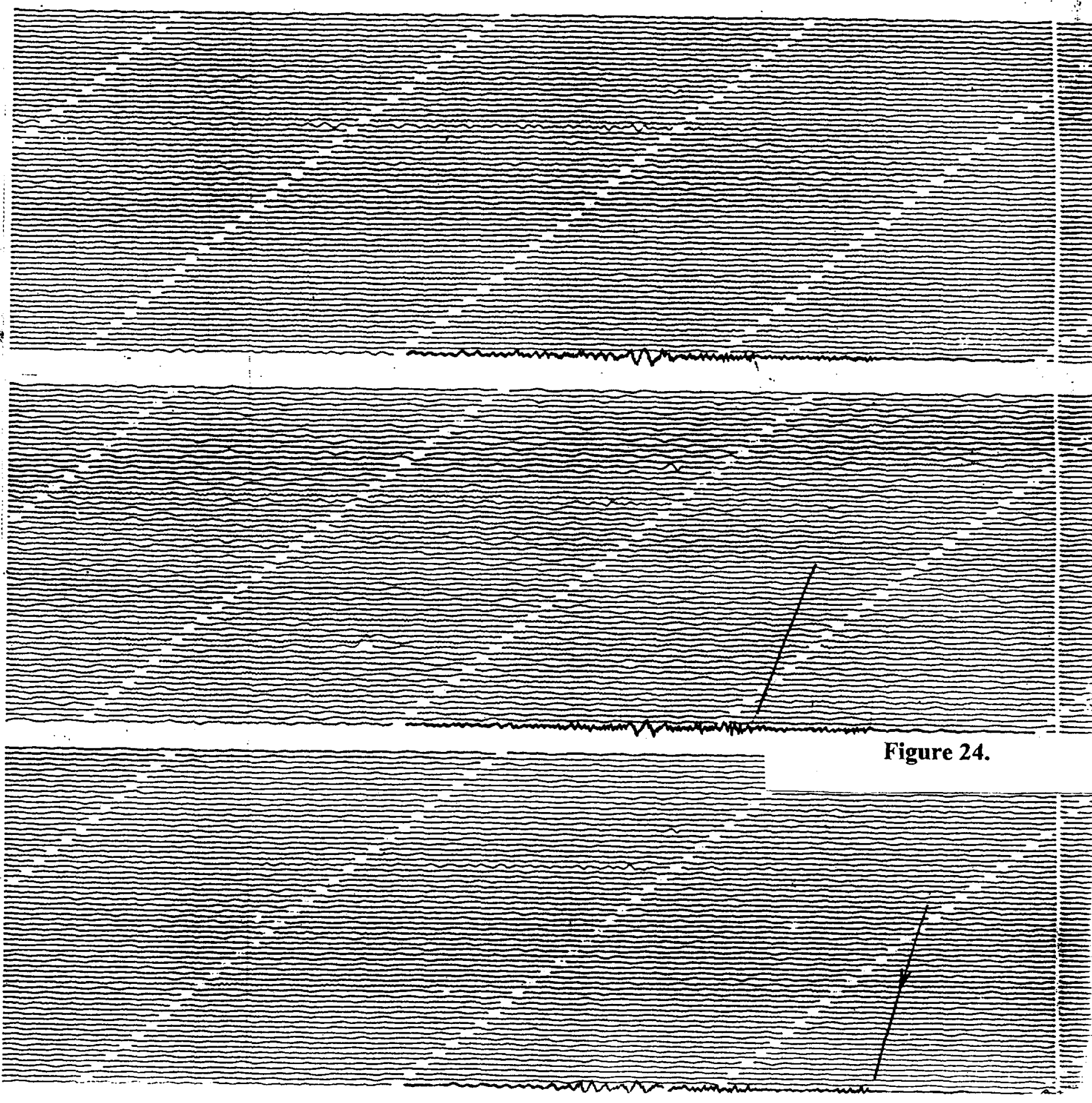


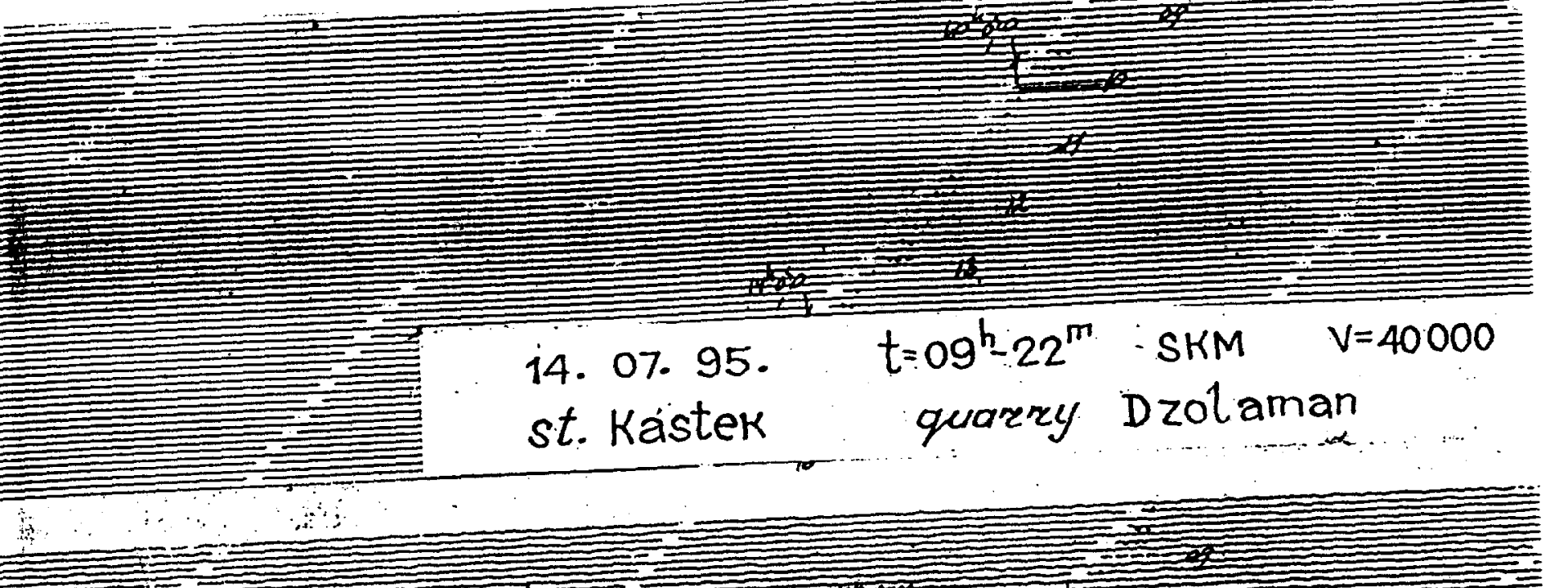



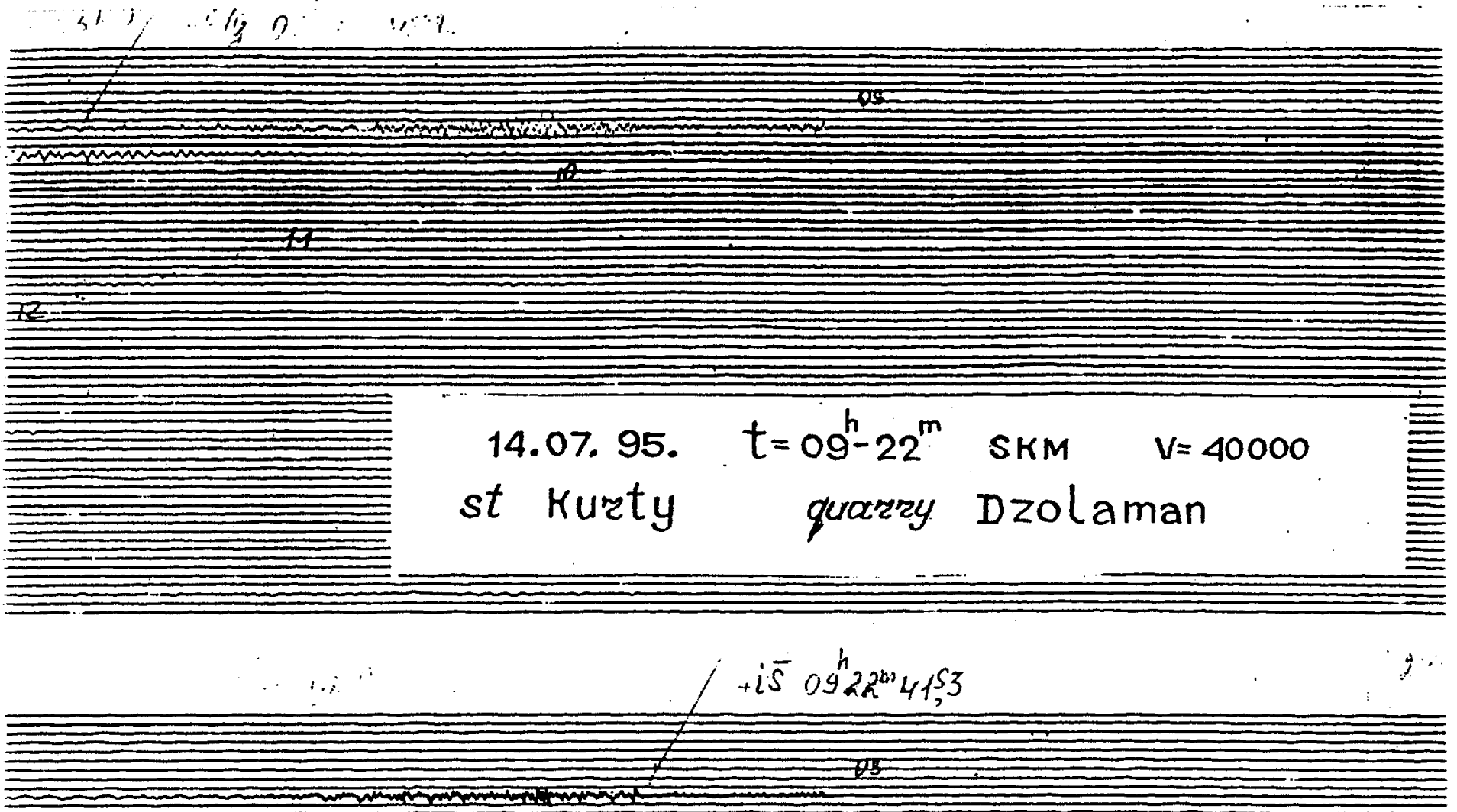

三

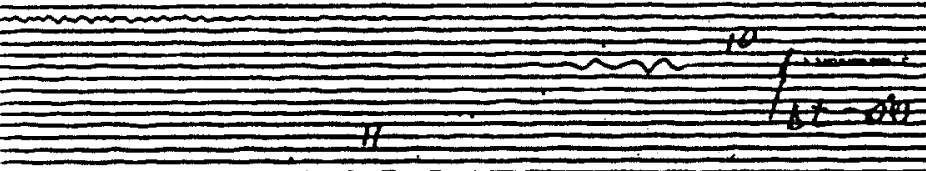

F
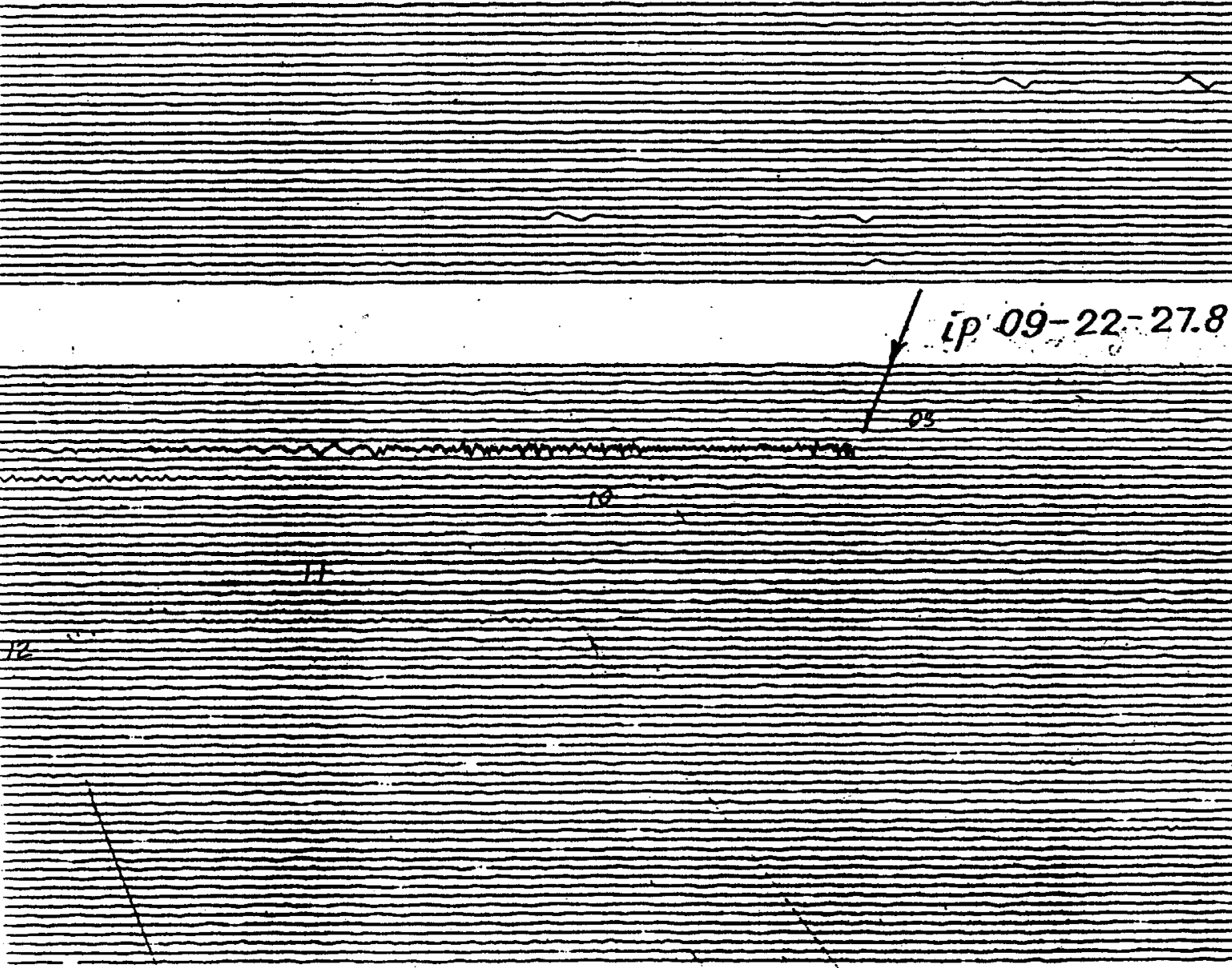

201020

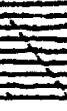

Figure 26. 


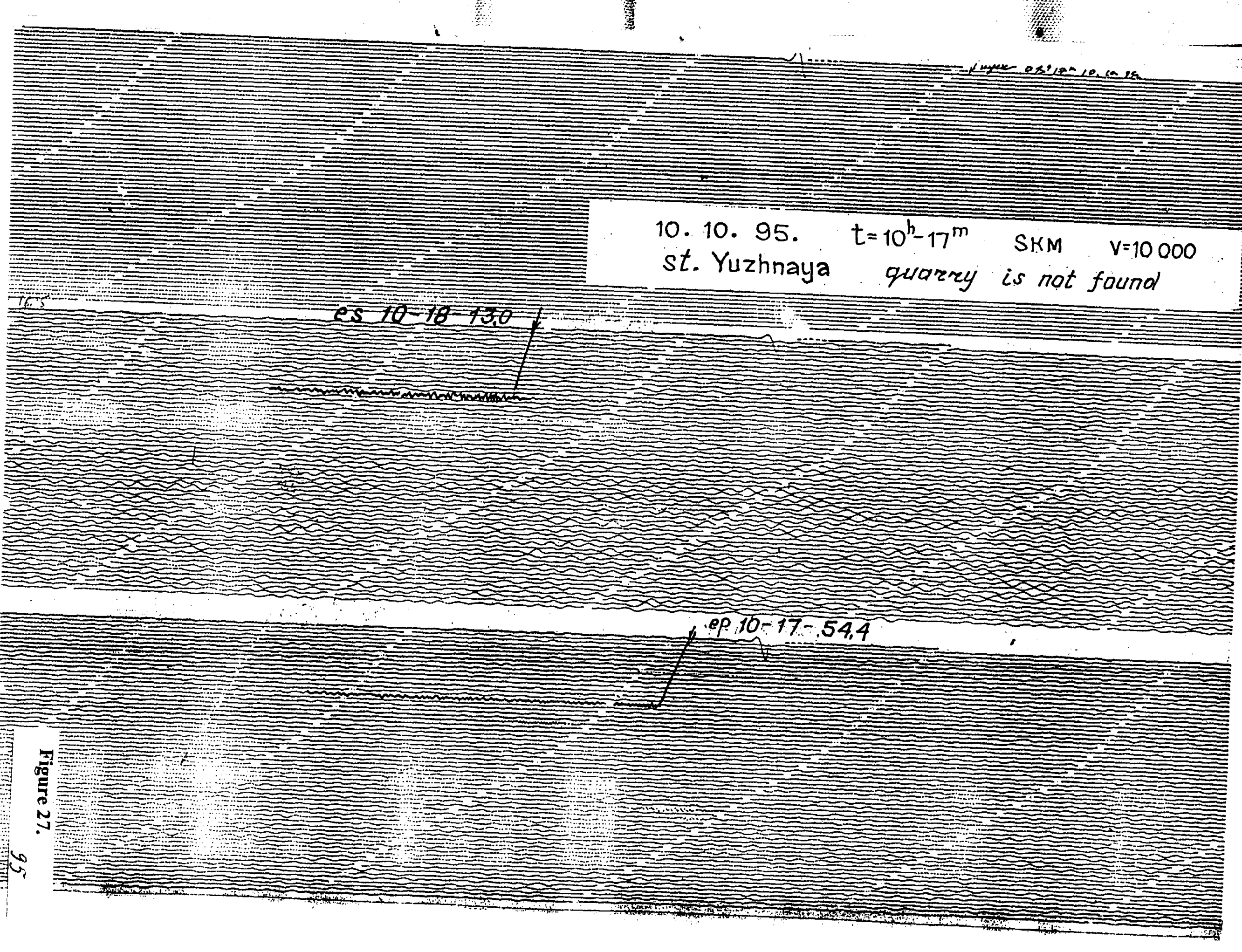




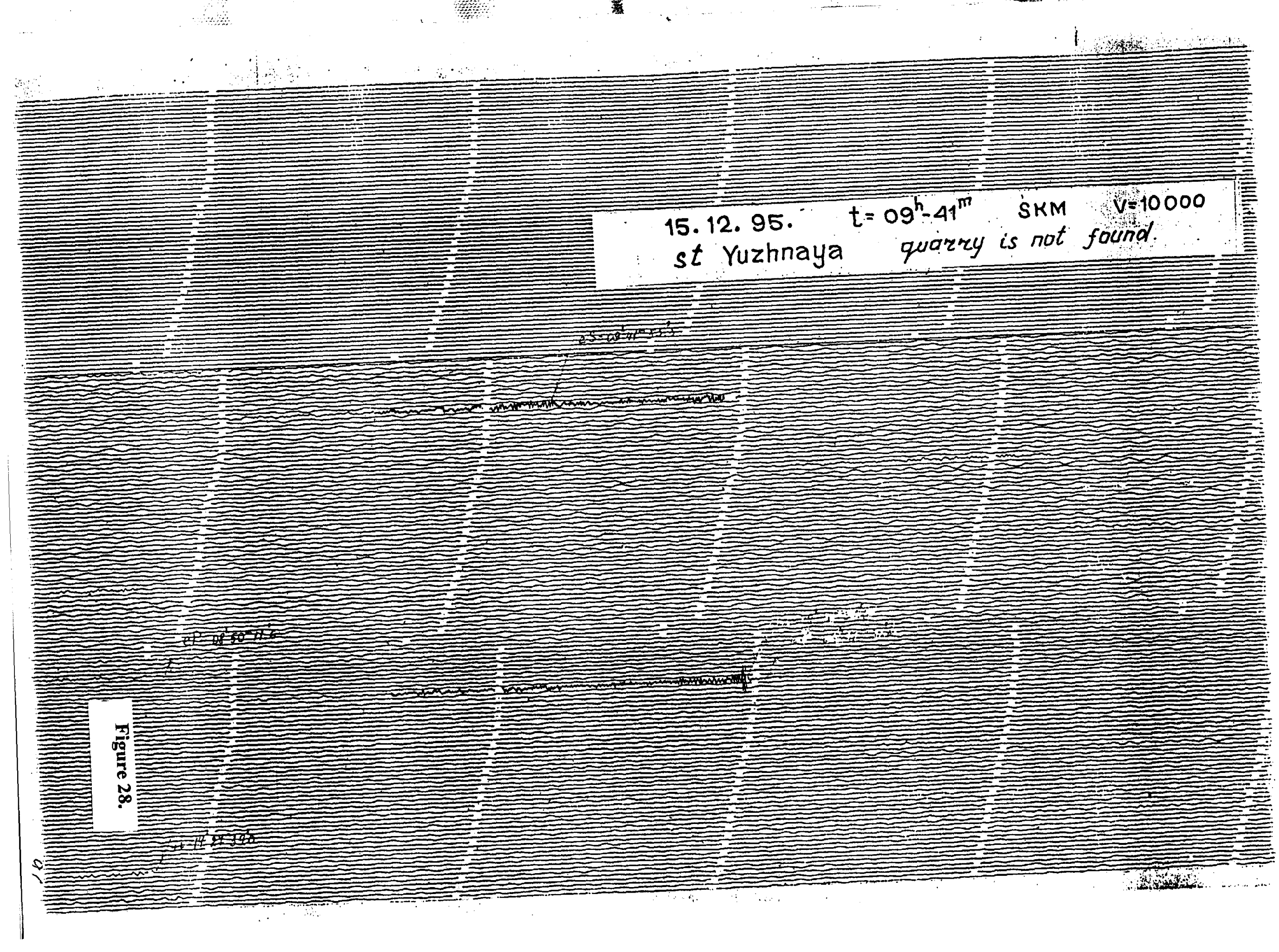




\section{12. 95. $t=08^{h}-40^{m}$ SKM. $\quad v=10000$ st. Taldy Korgan quarzy Kusakskiy}
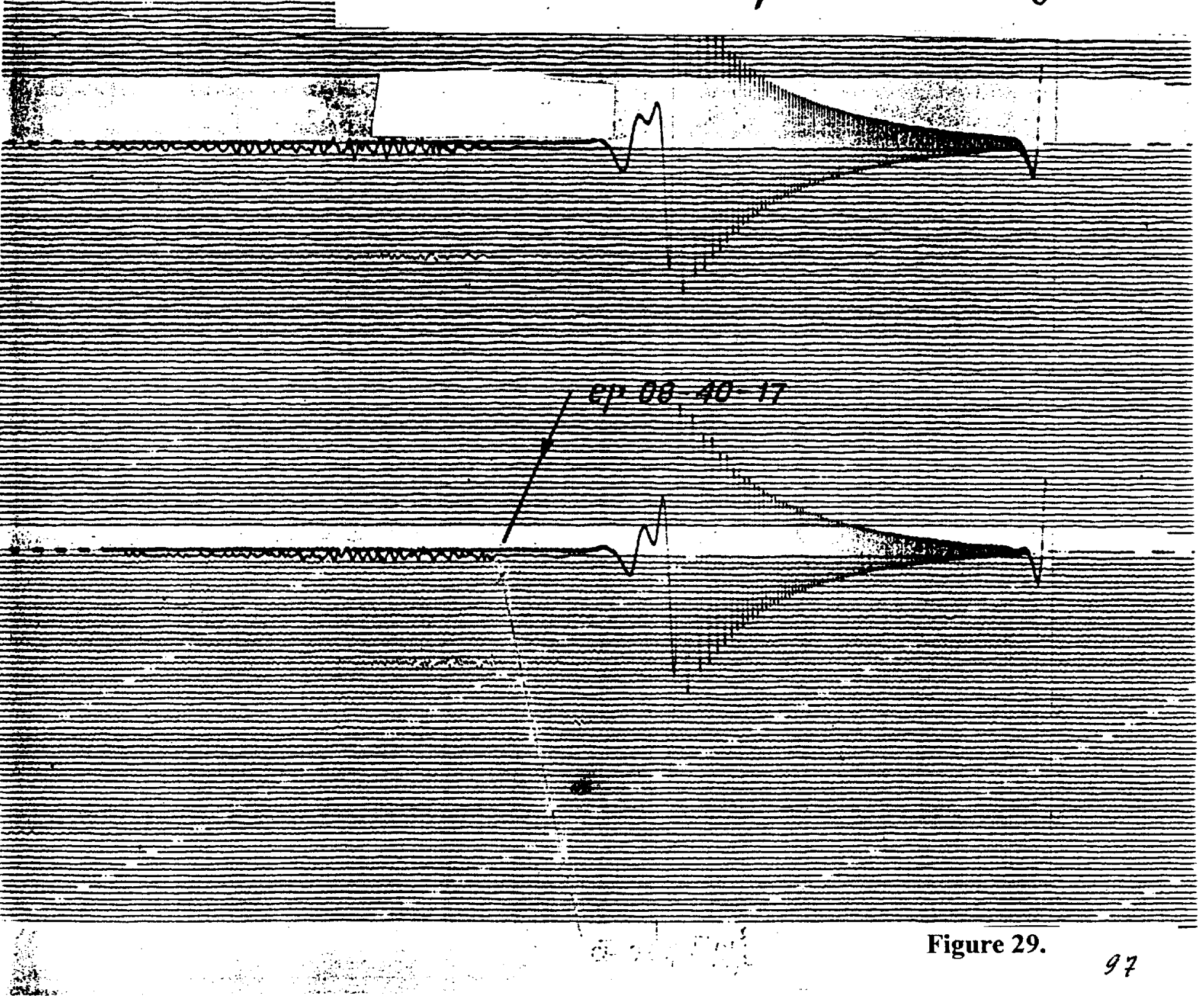


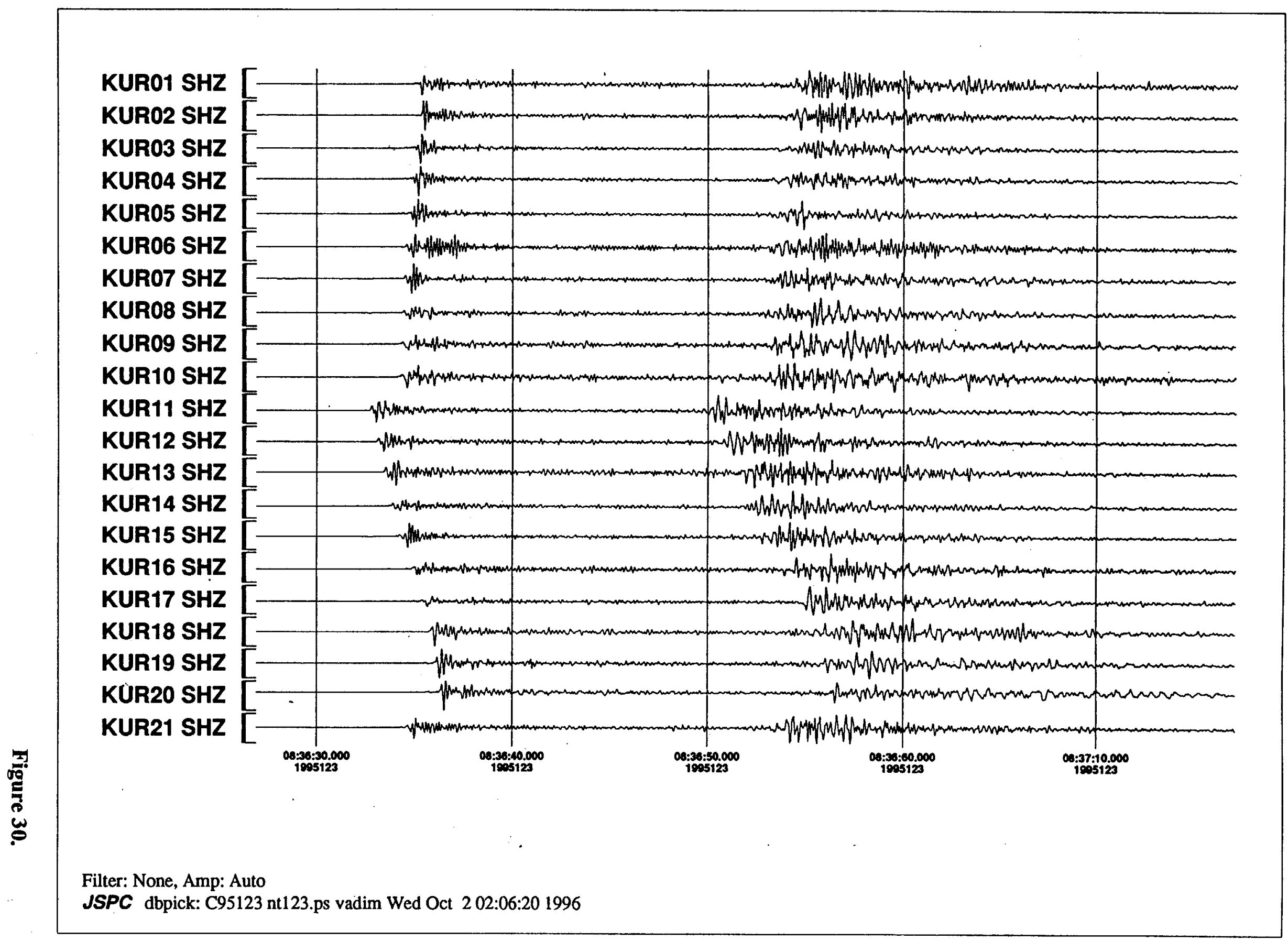




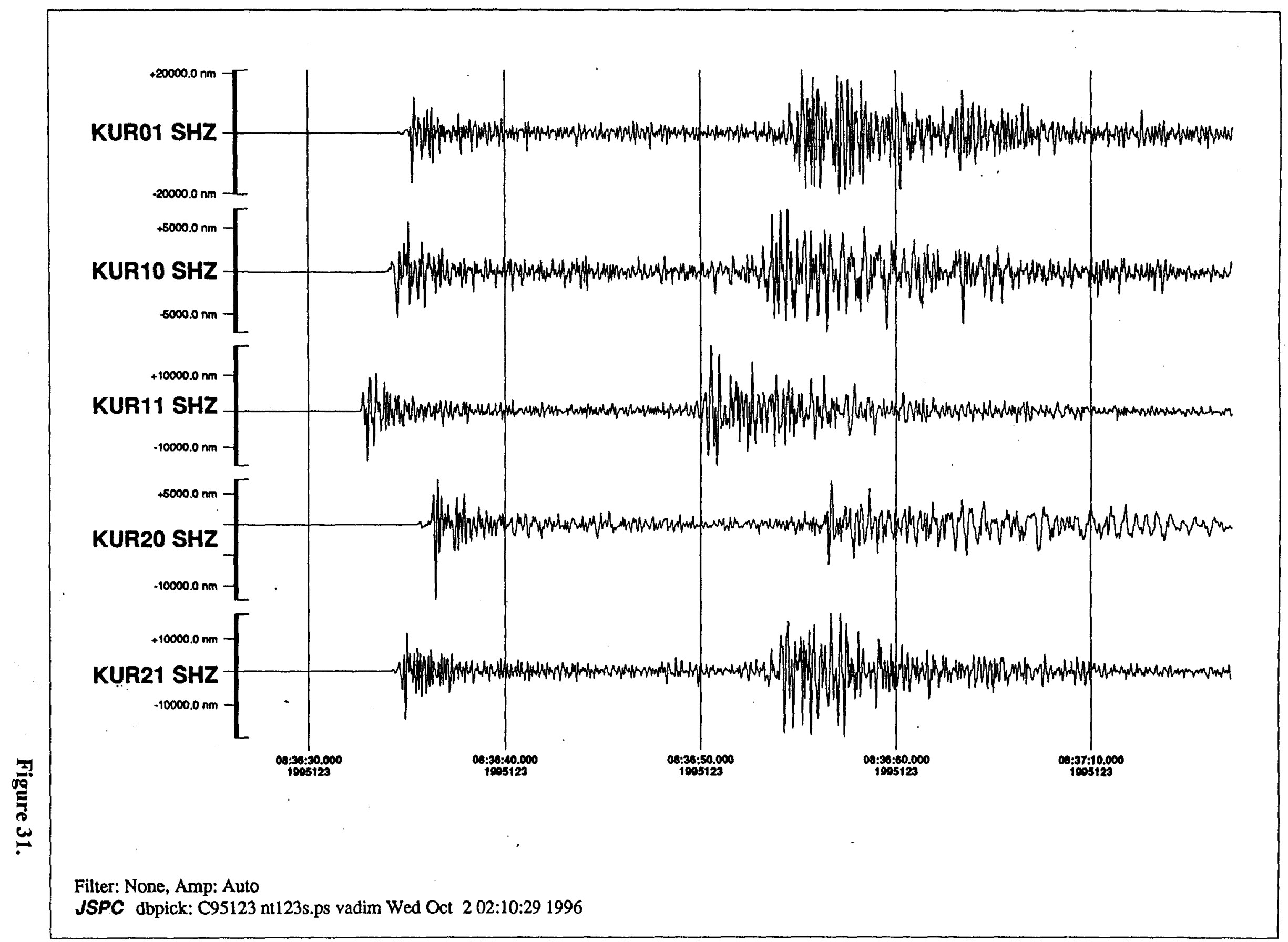




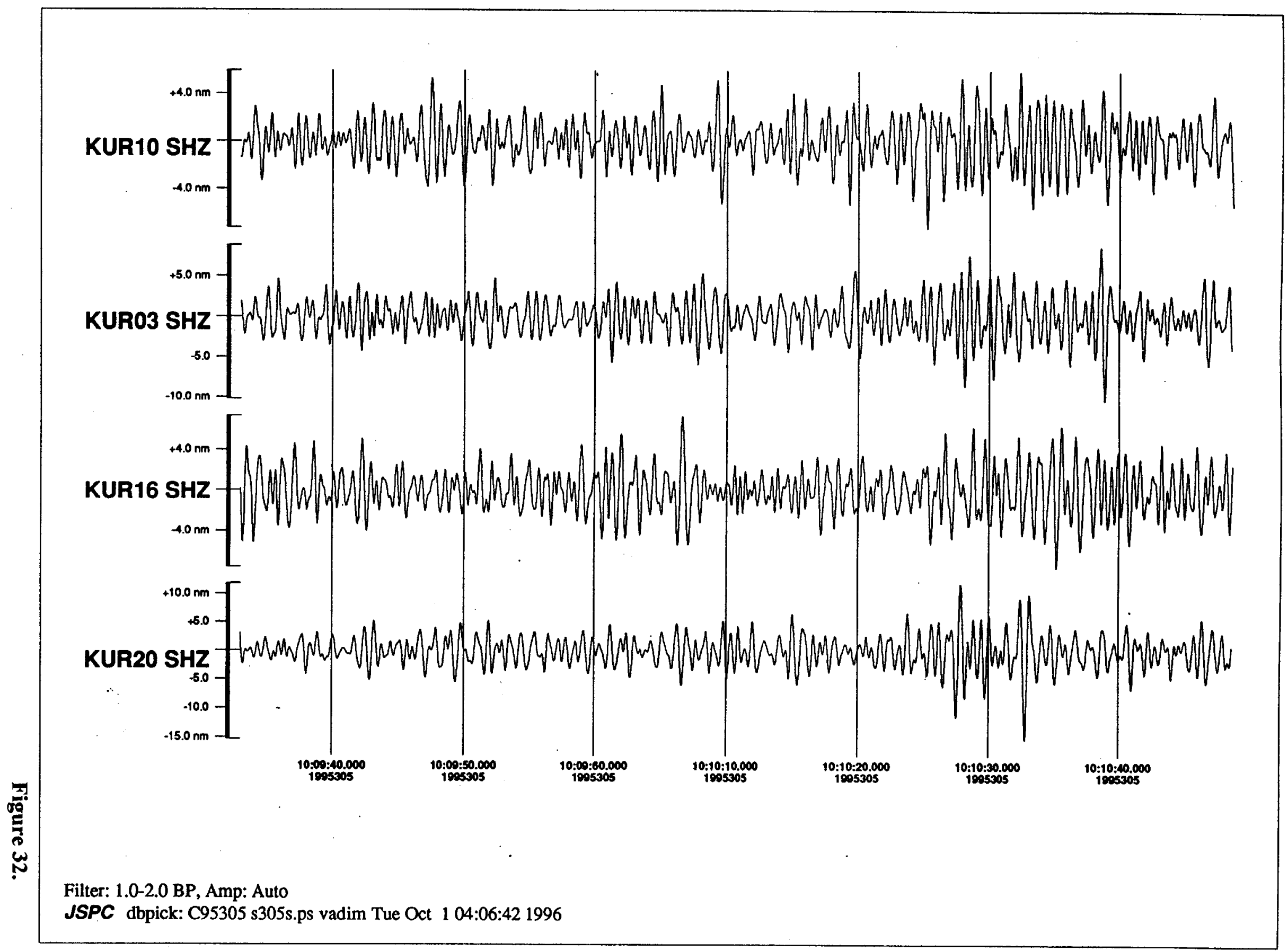




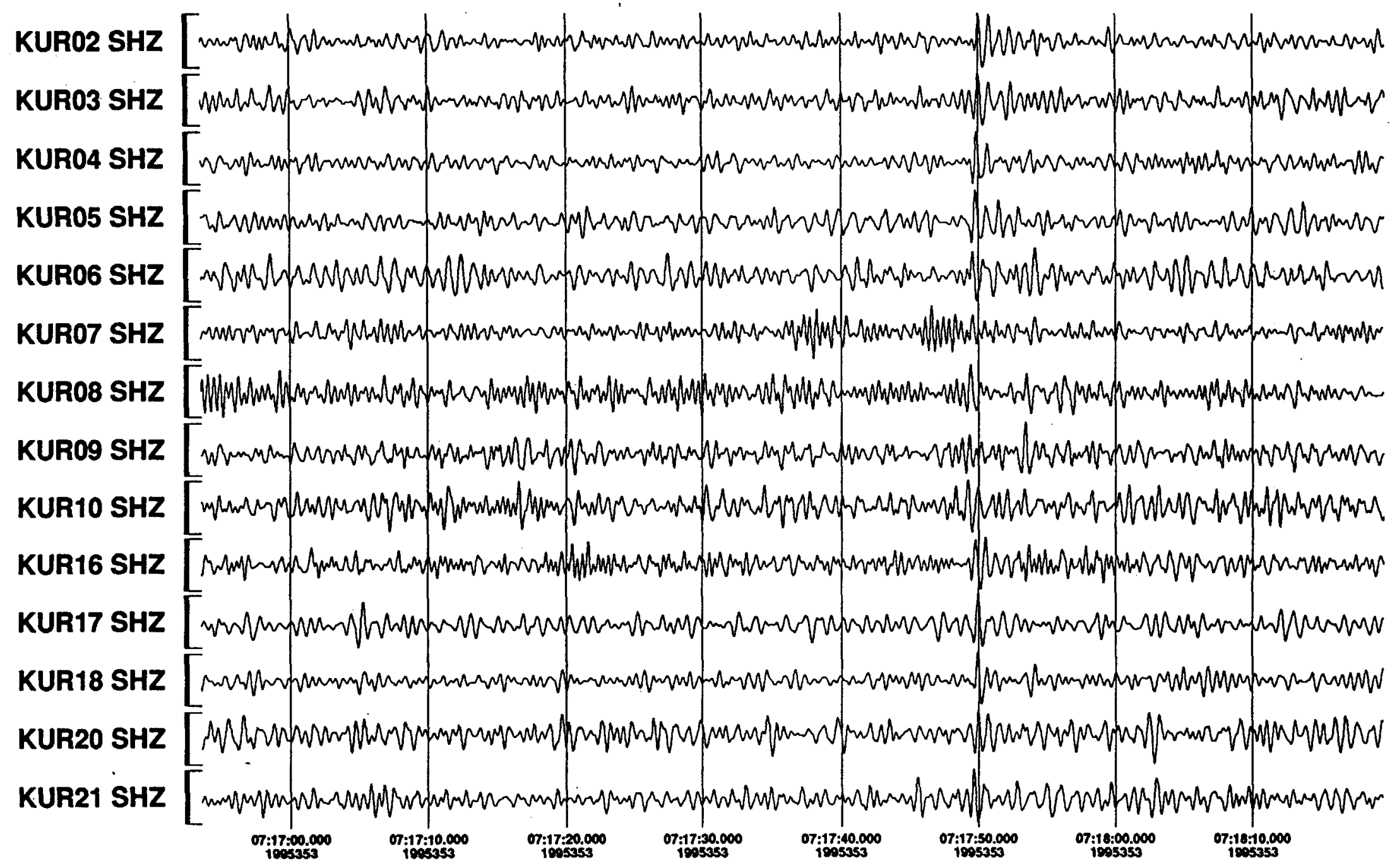

Filter: 1.0-2.0 BP, Amp: Auto

JSPC dbpick: C95353 nt353.ps vadim Thu Oct 3 05:15:58 1996 


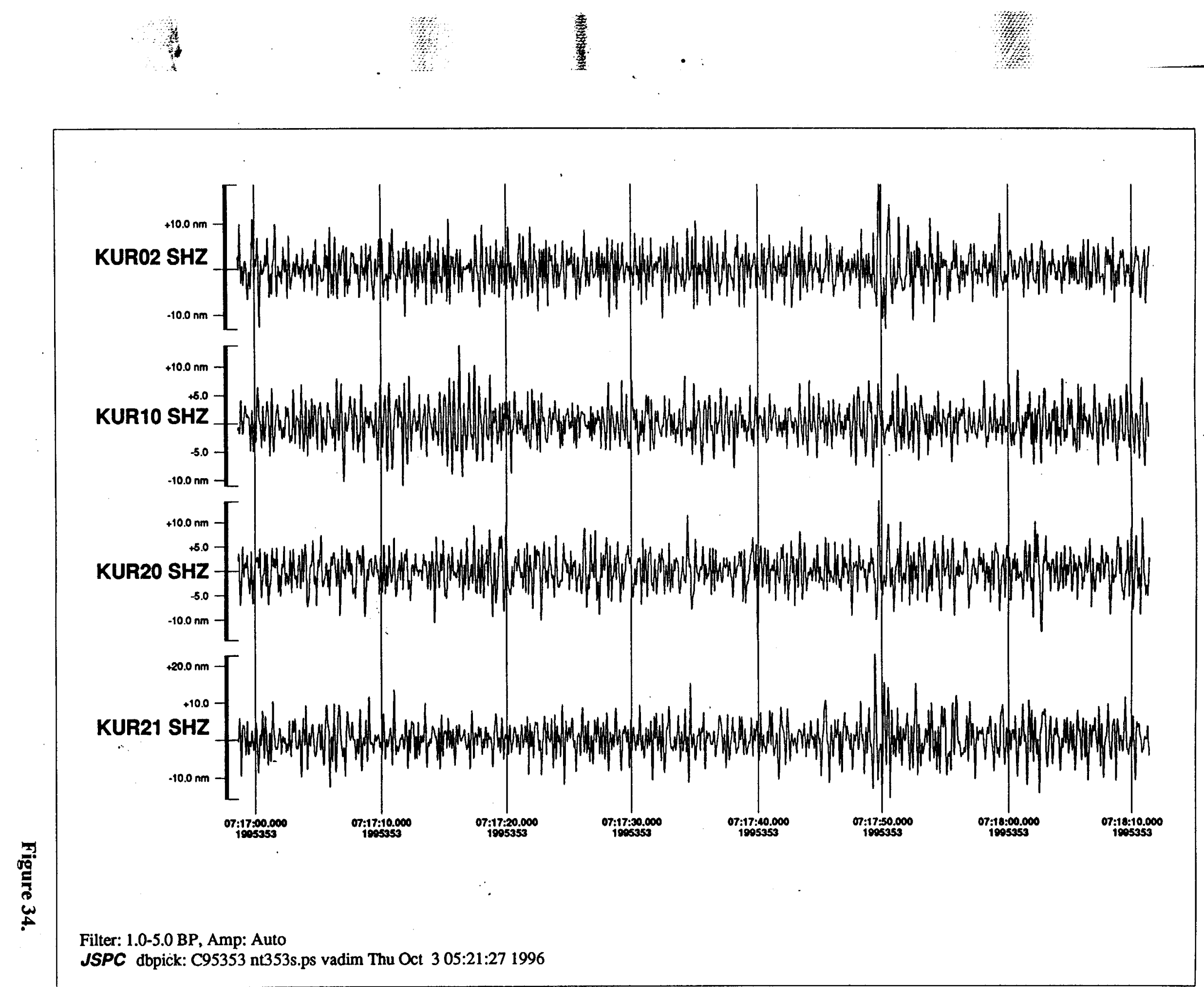



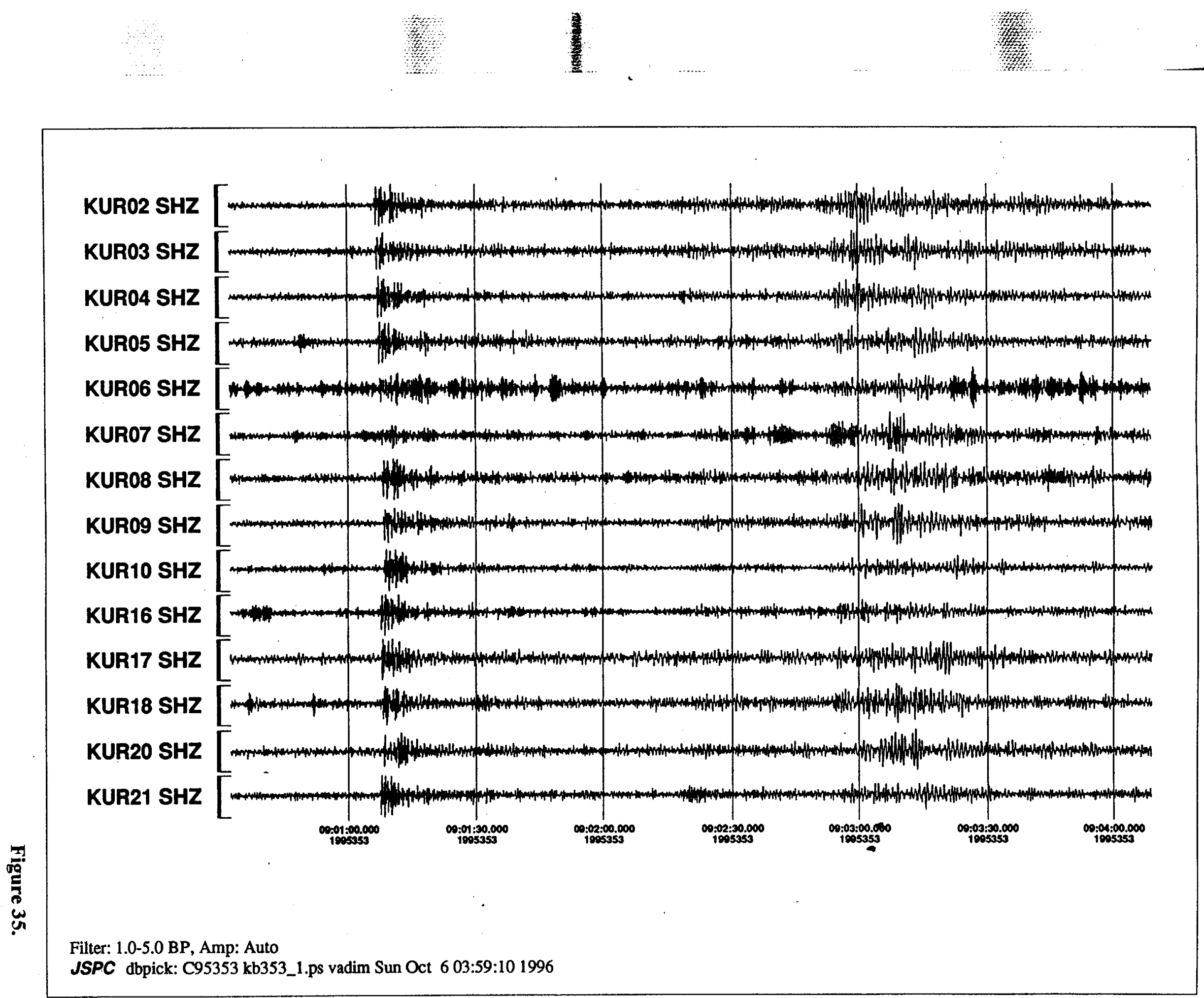

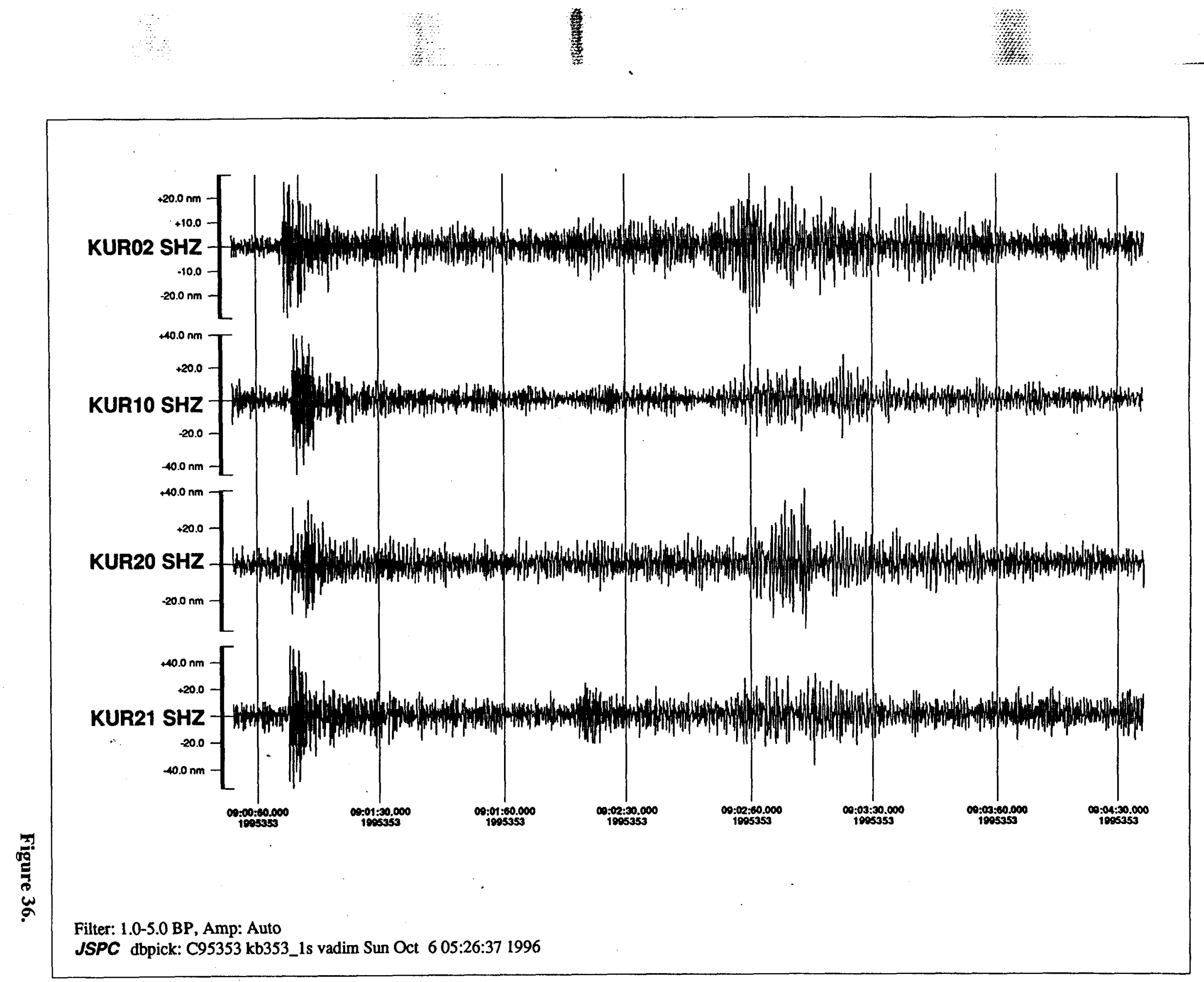

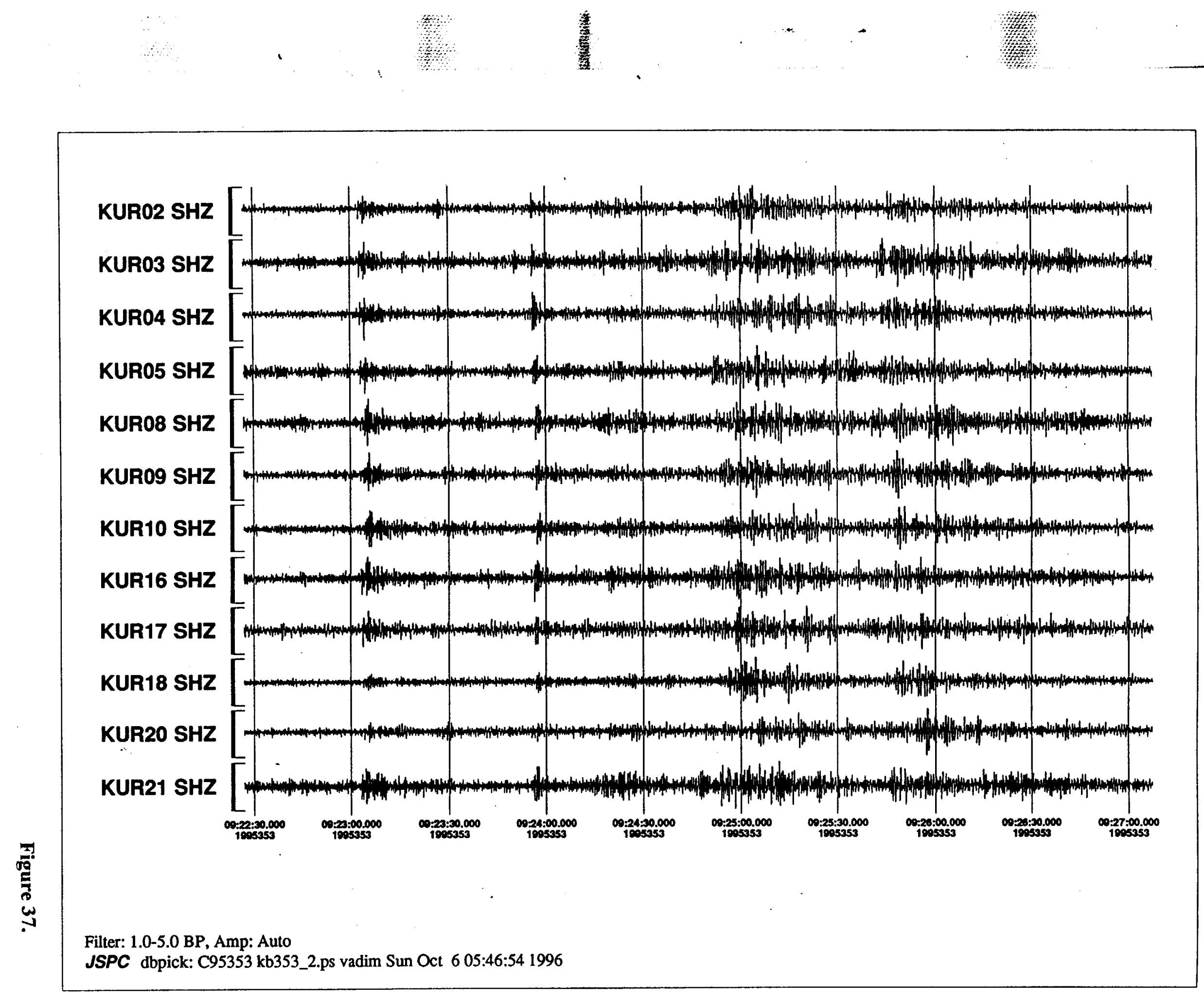


\section{新 \\ 1}

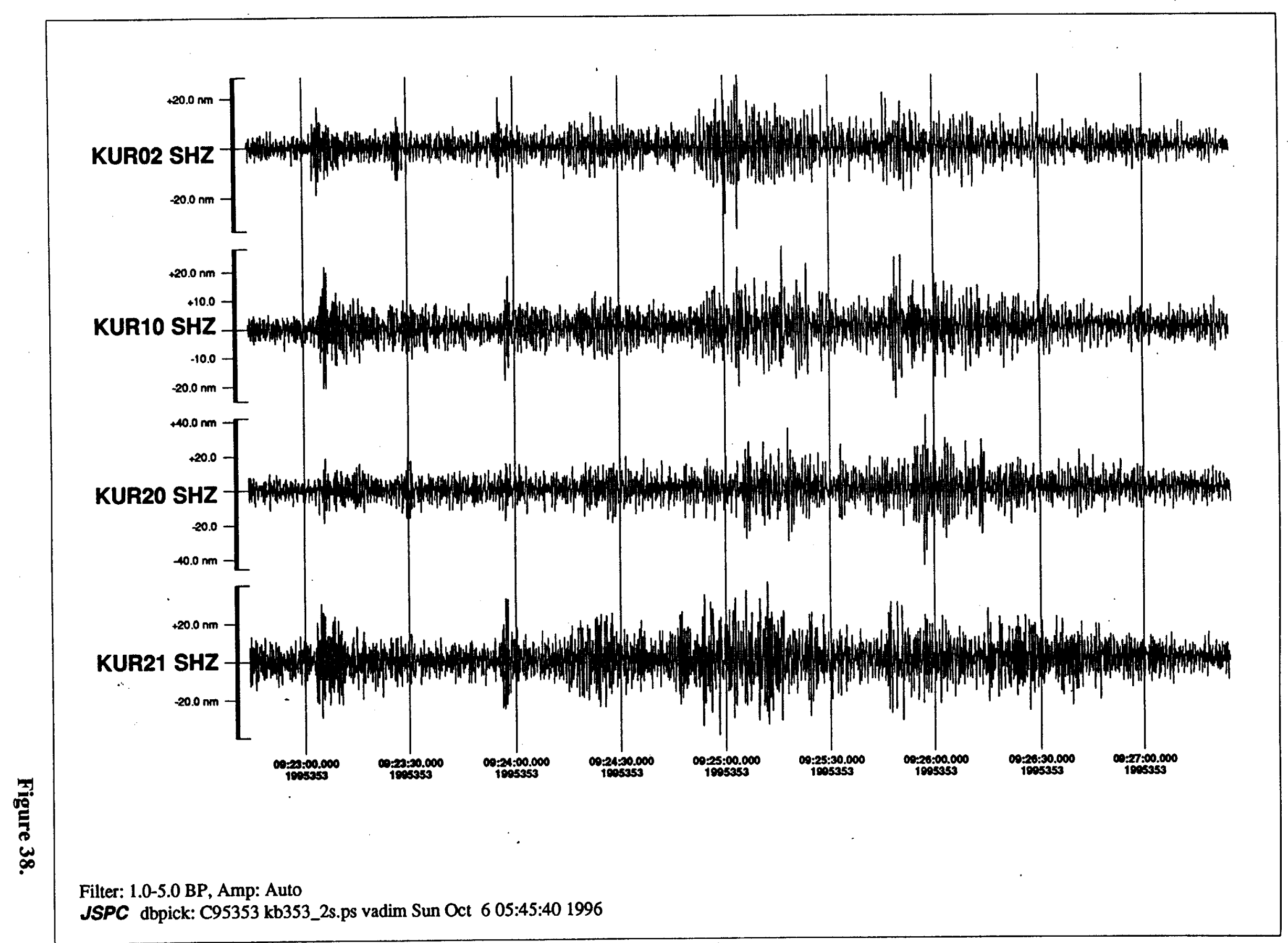




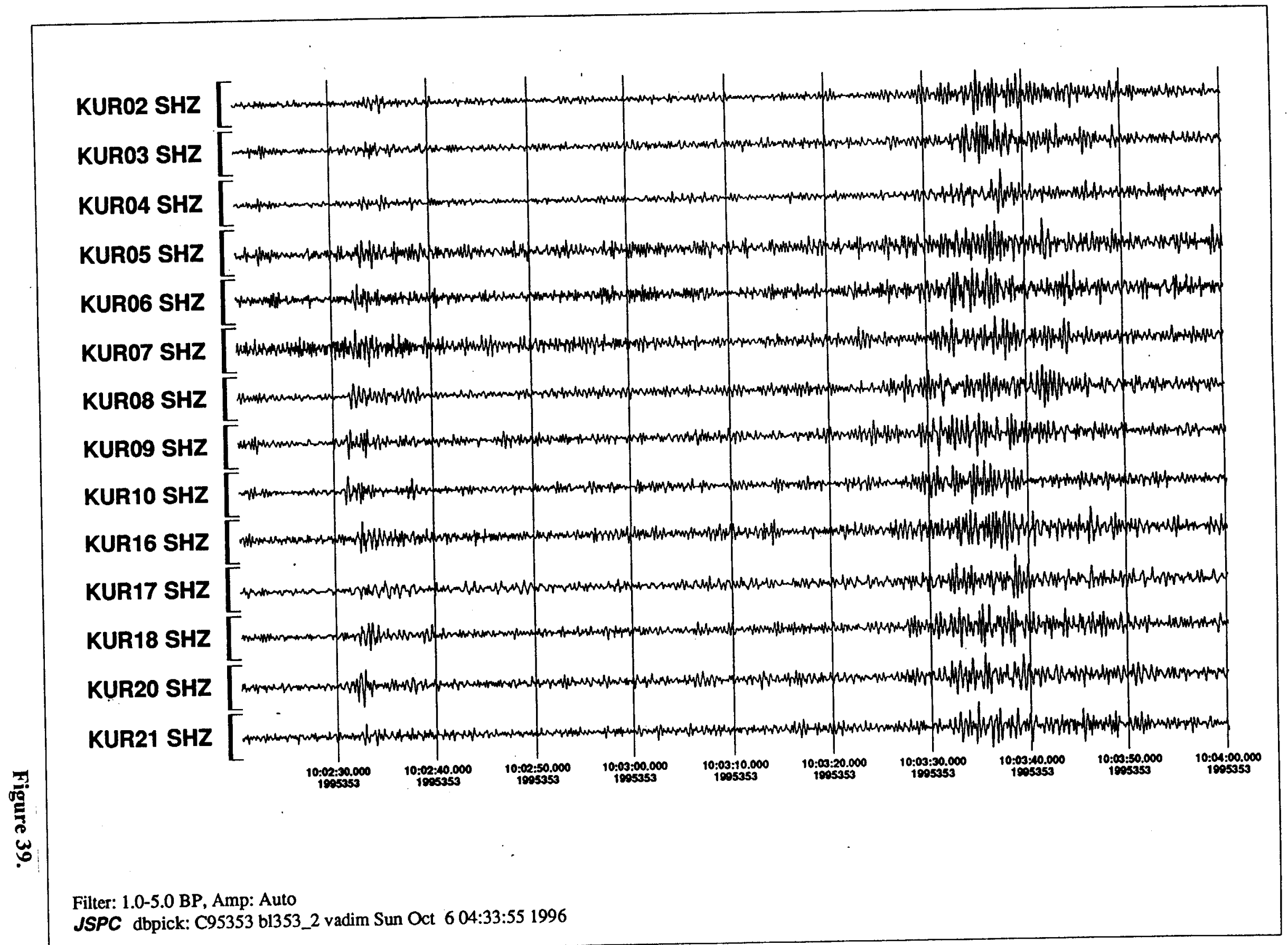




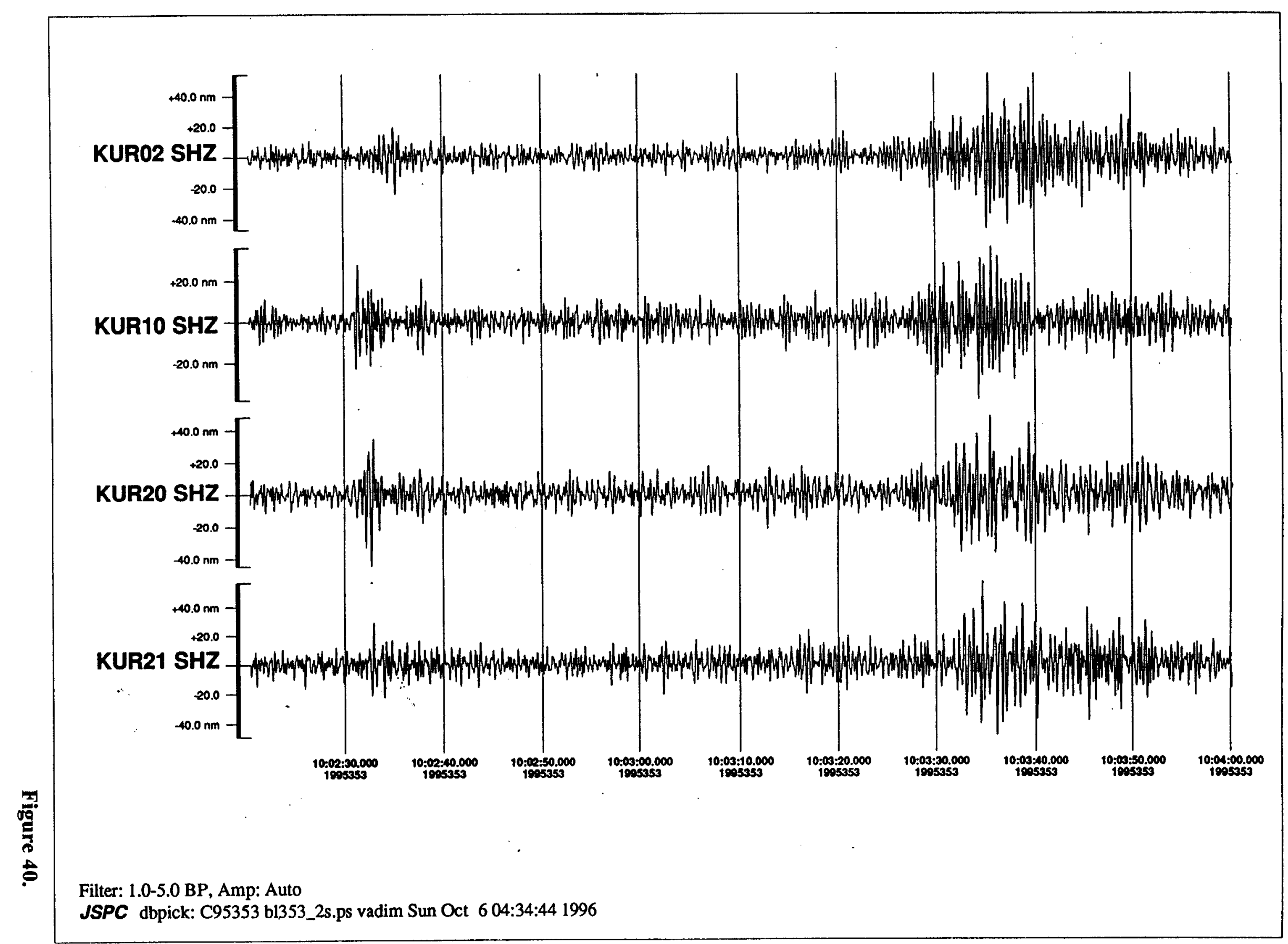




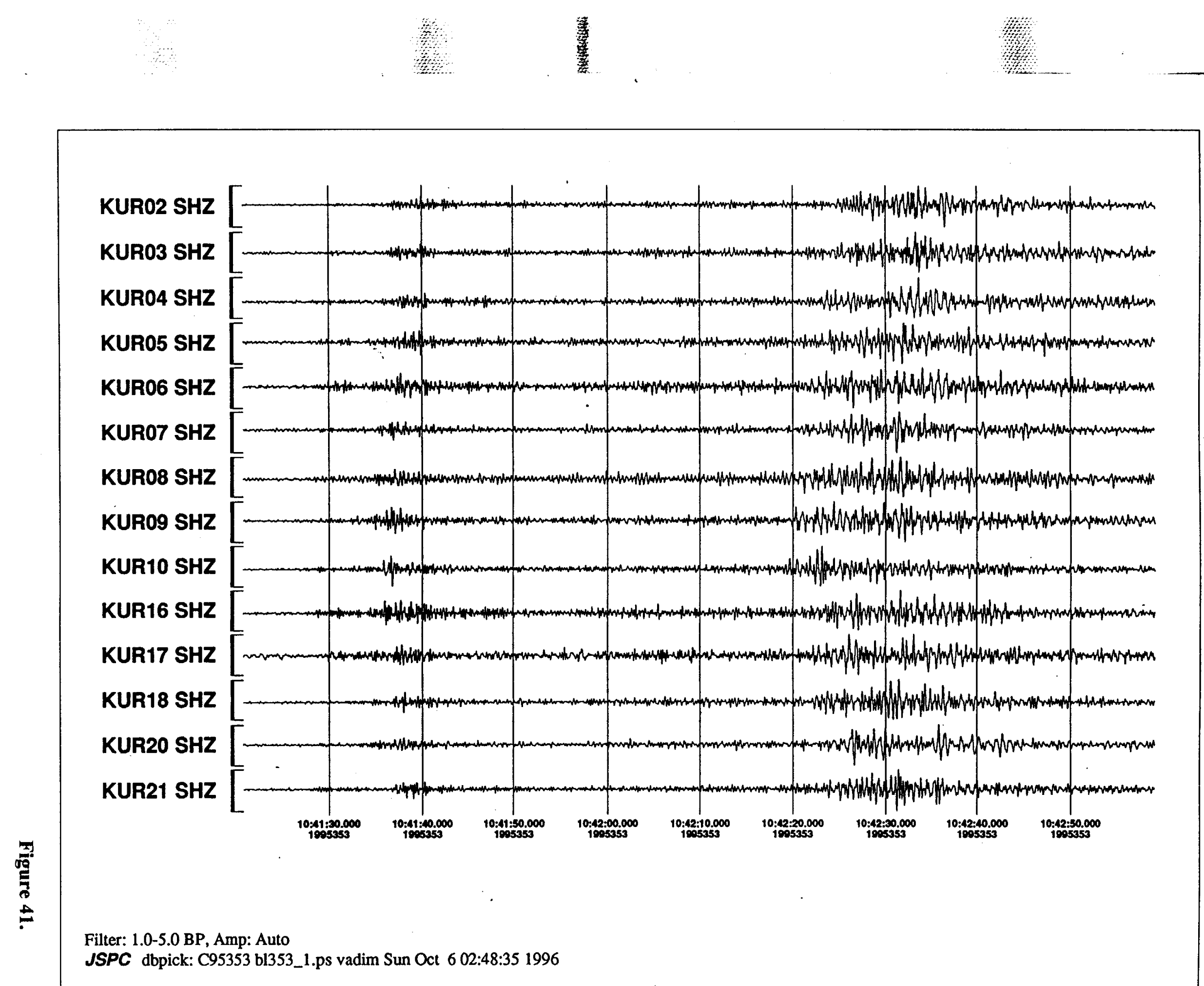




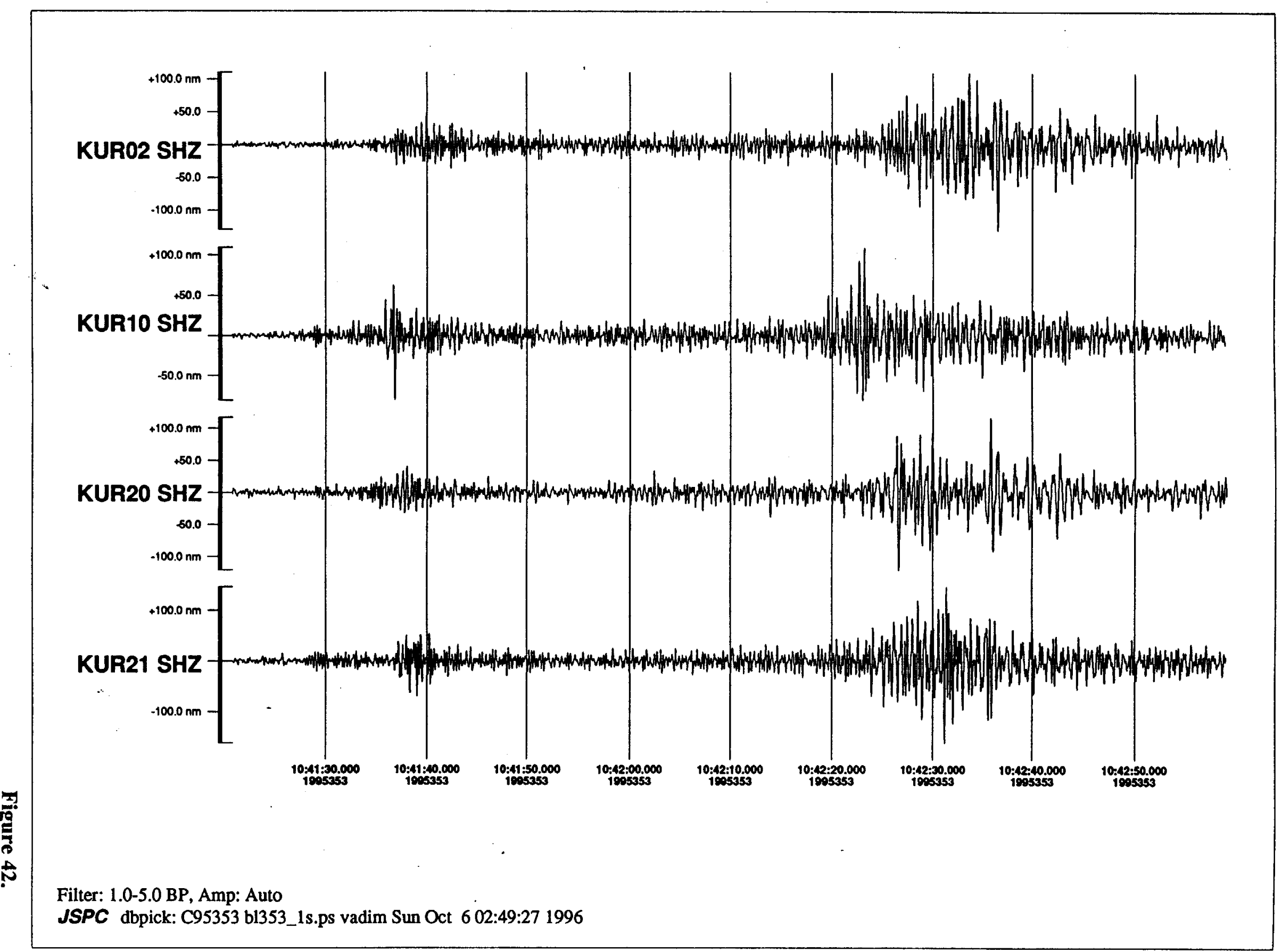




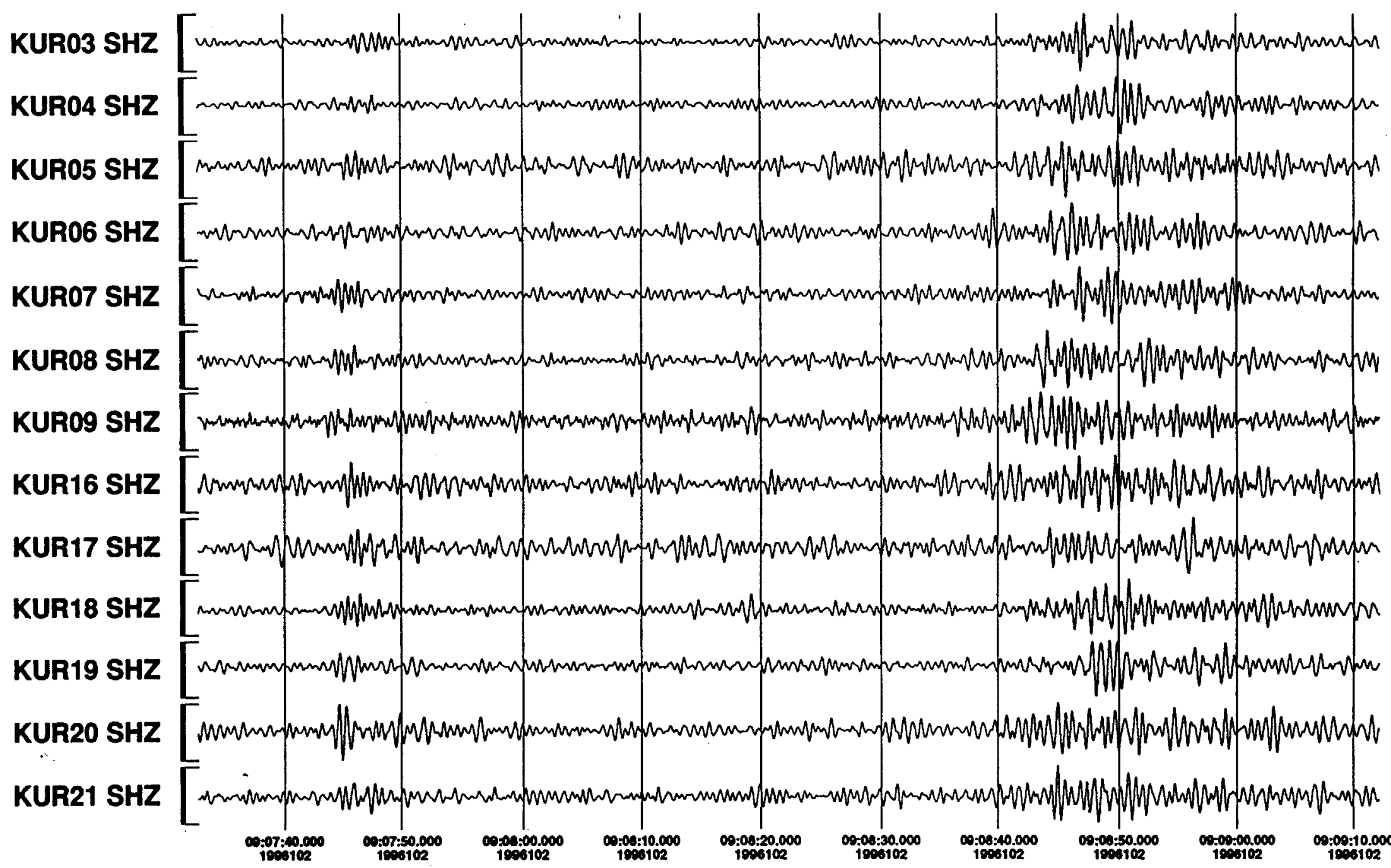




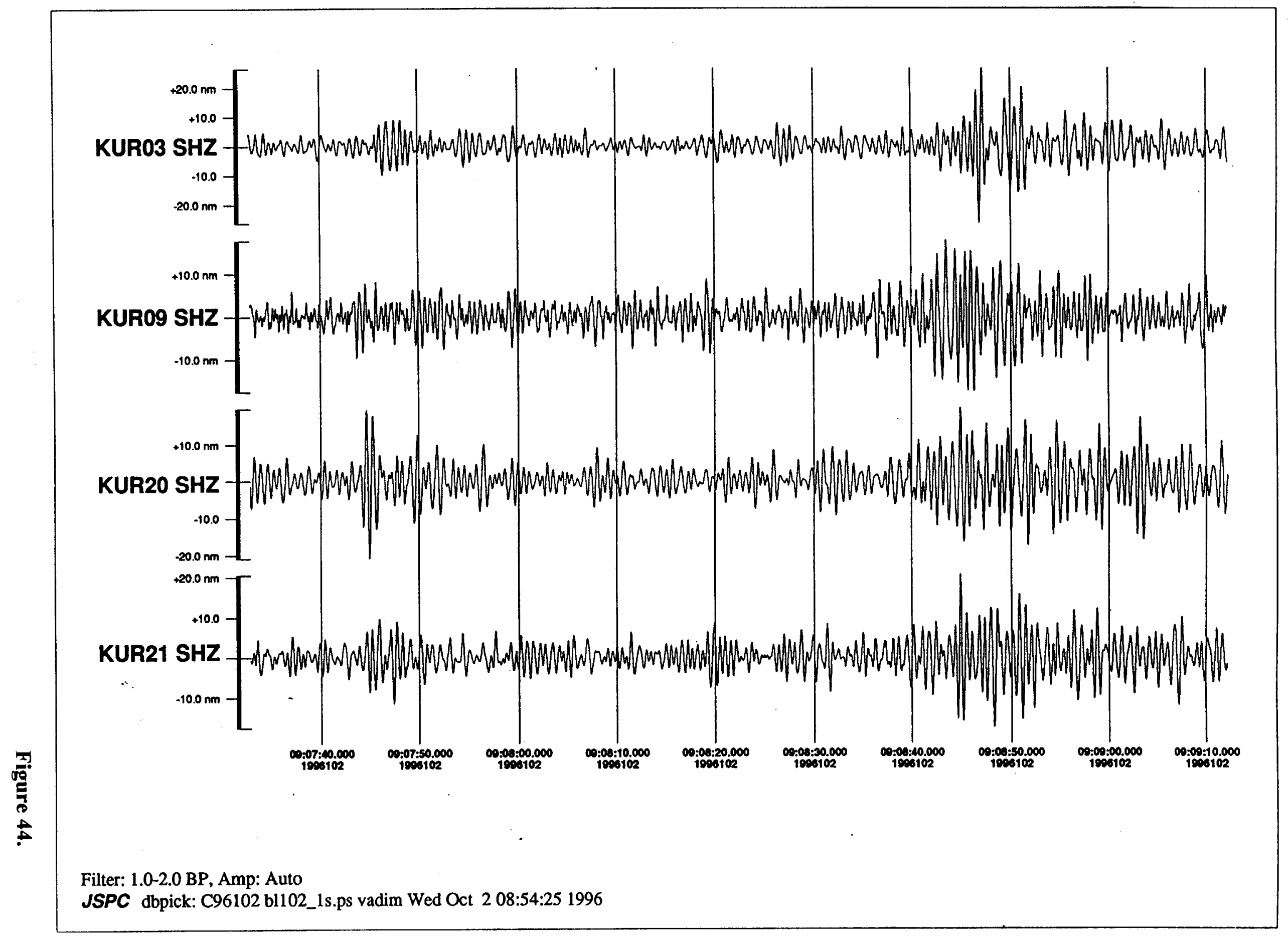




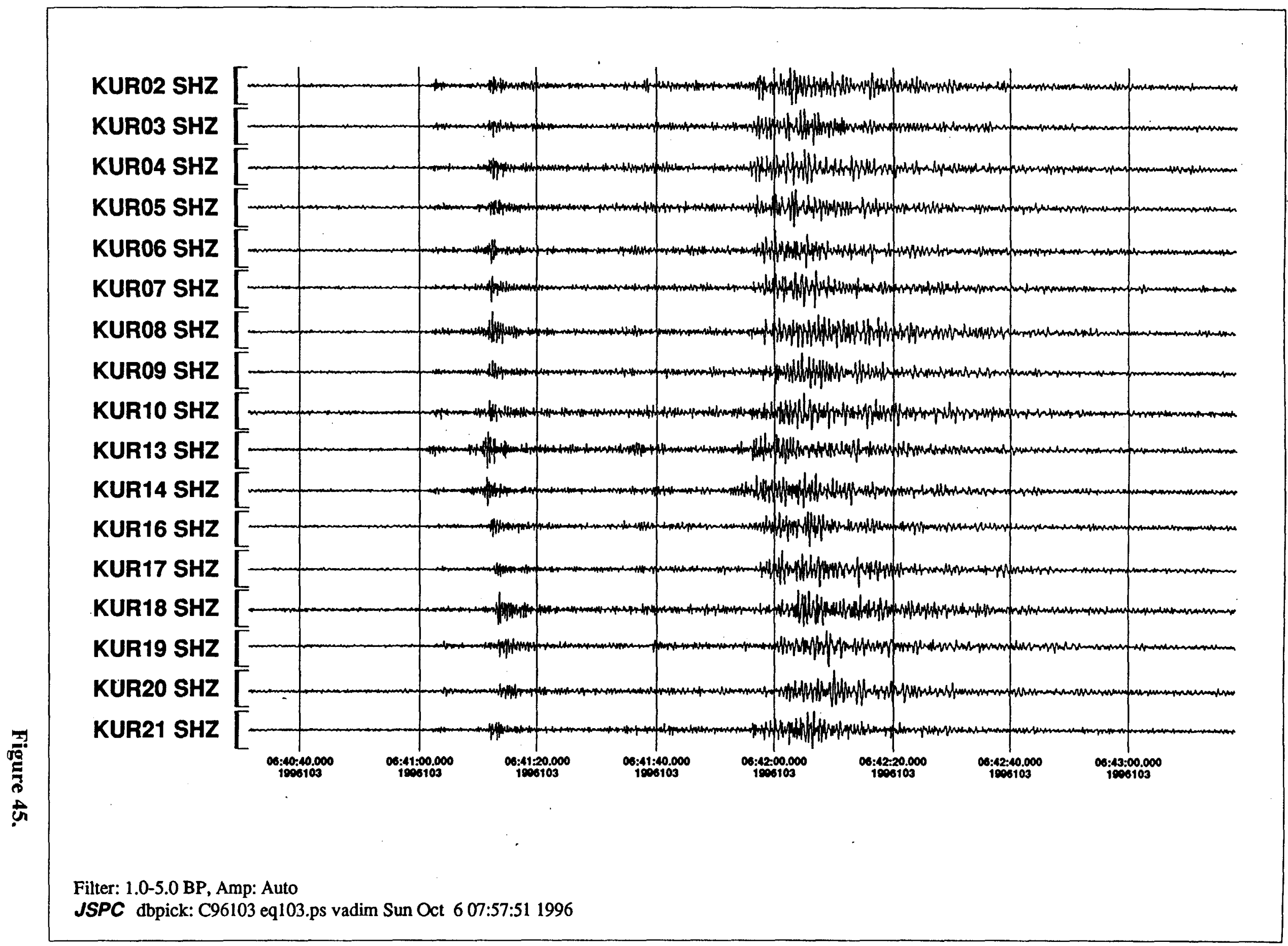




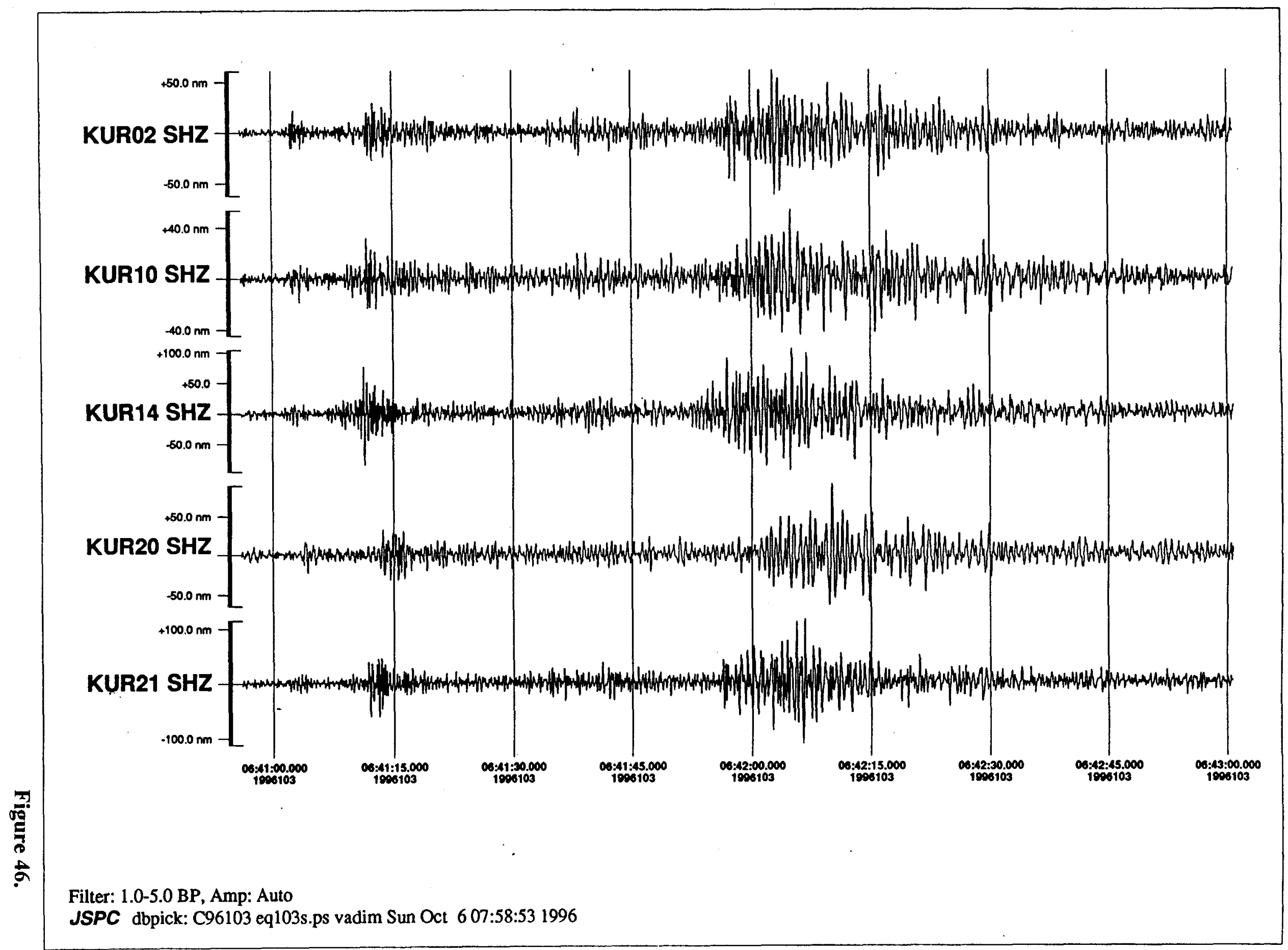




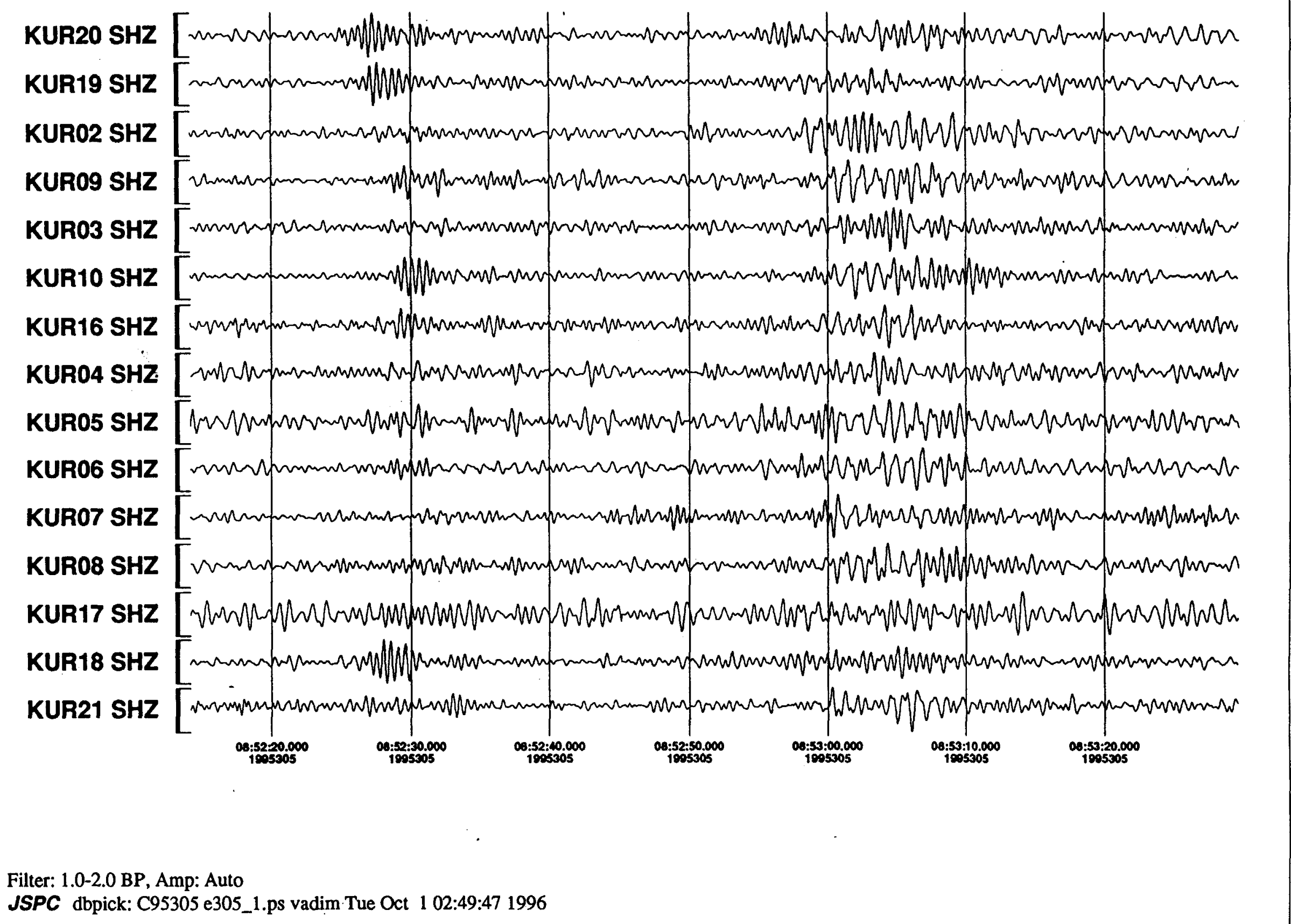




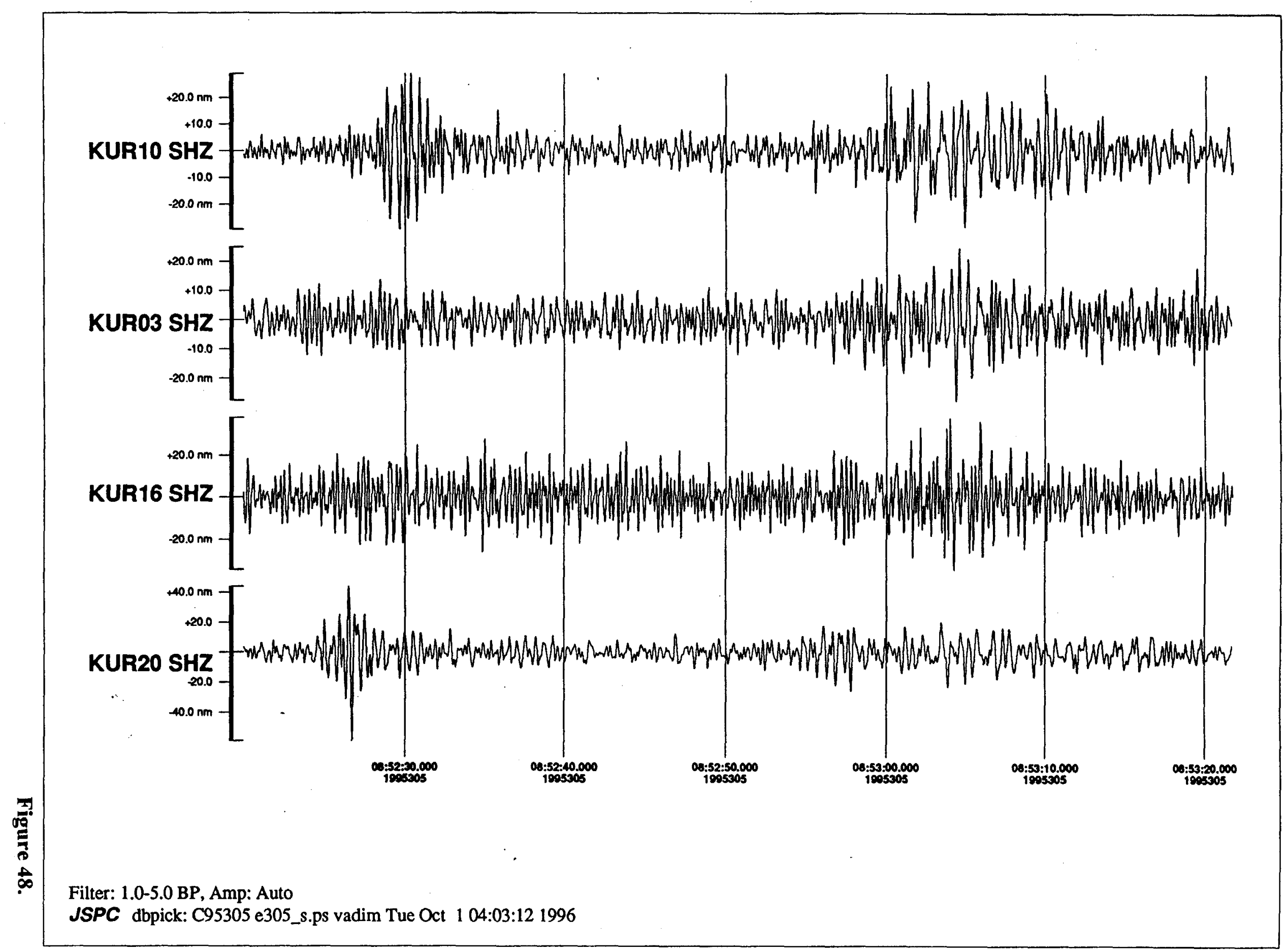




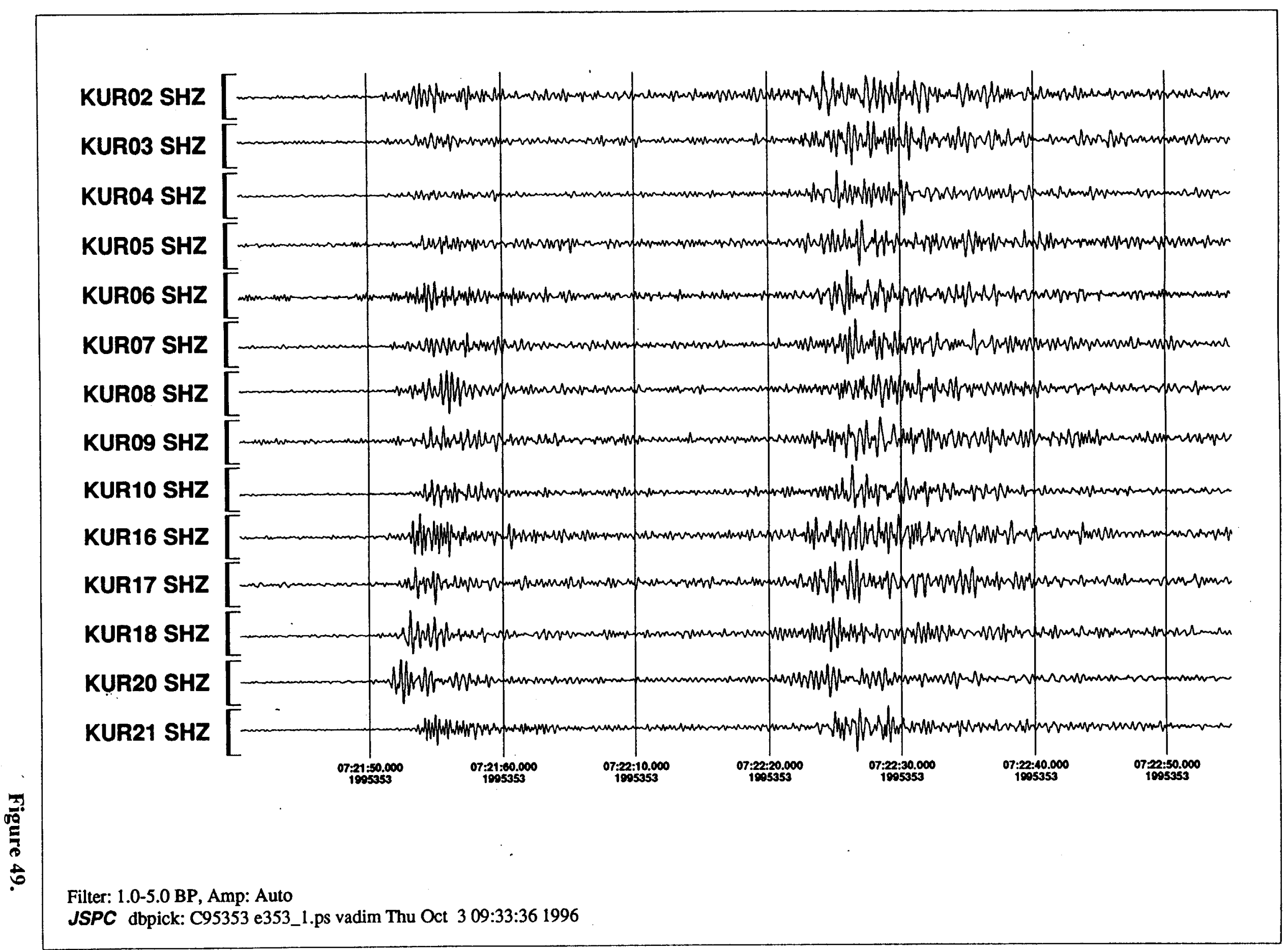




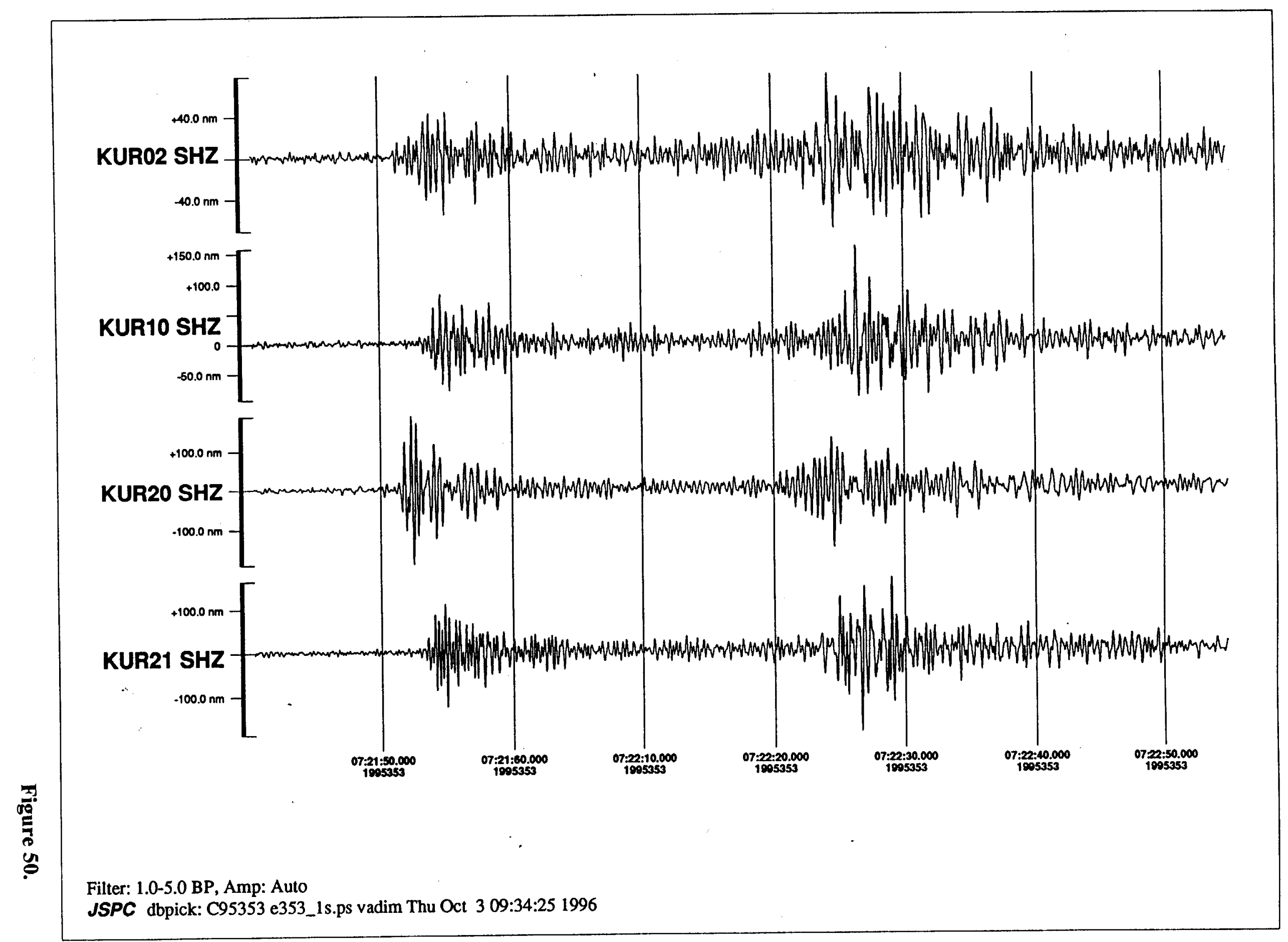




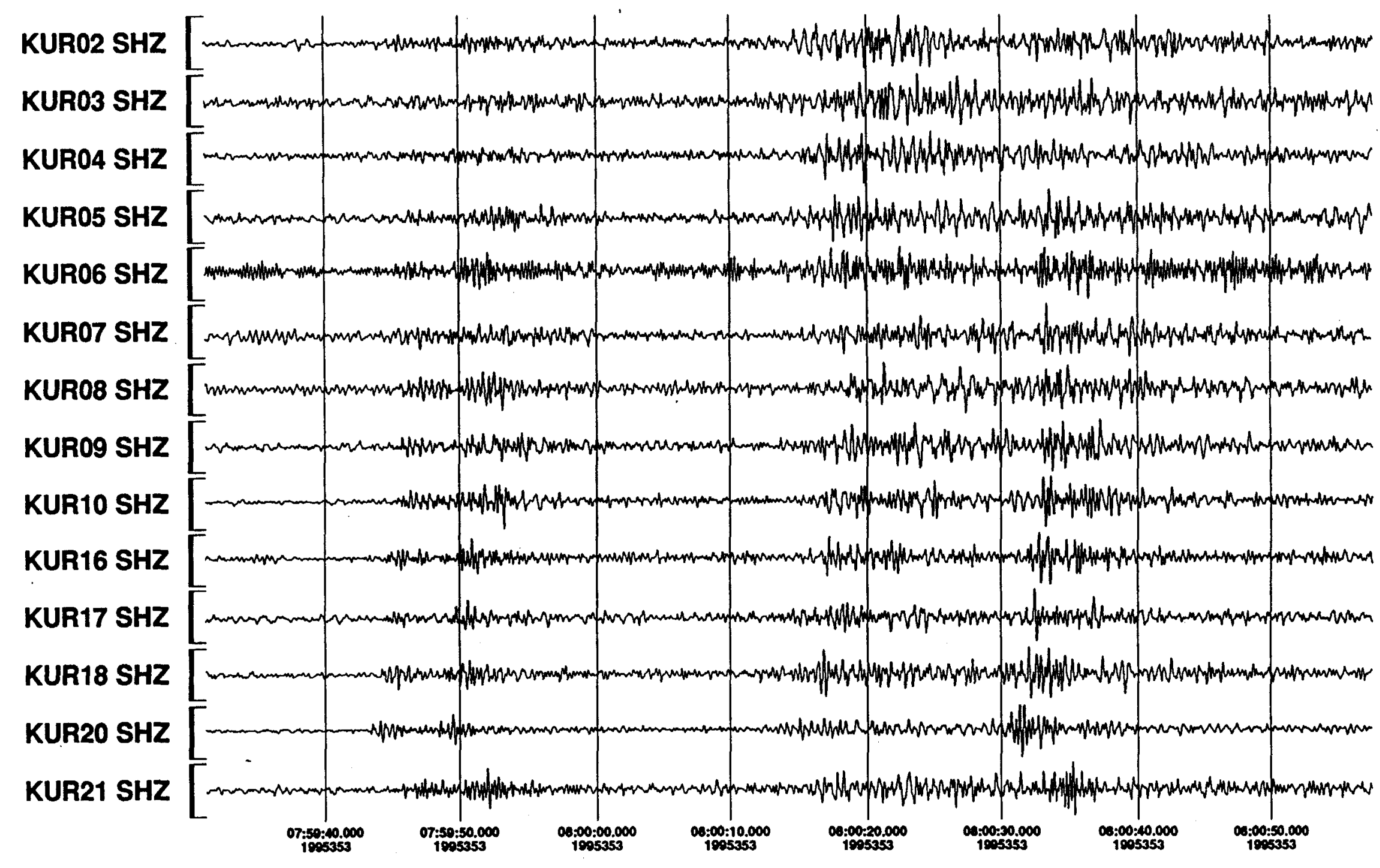




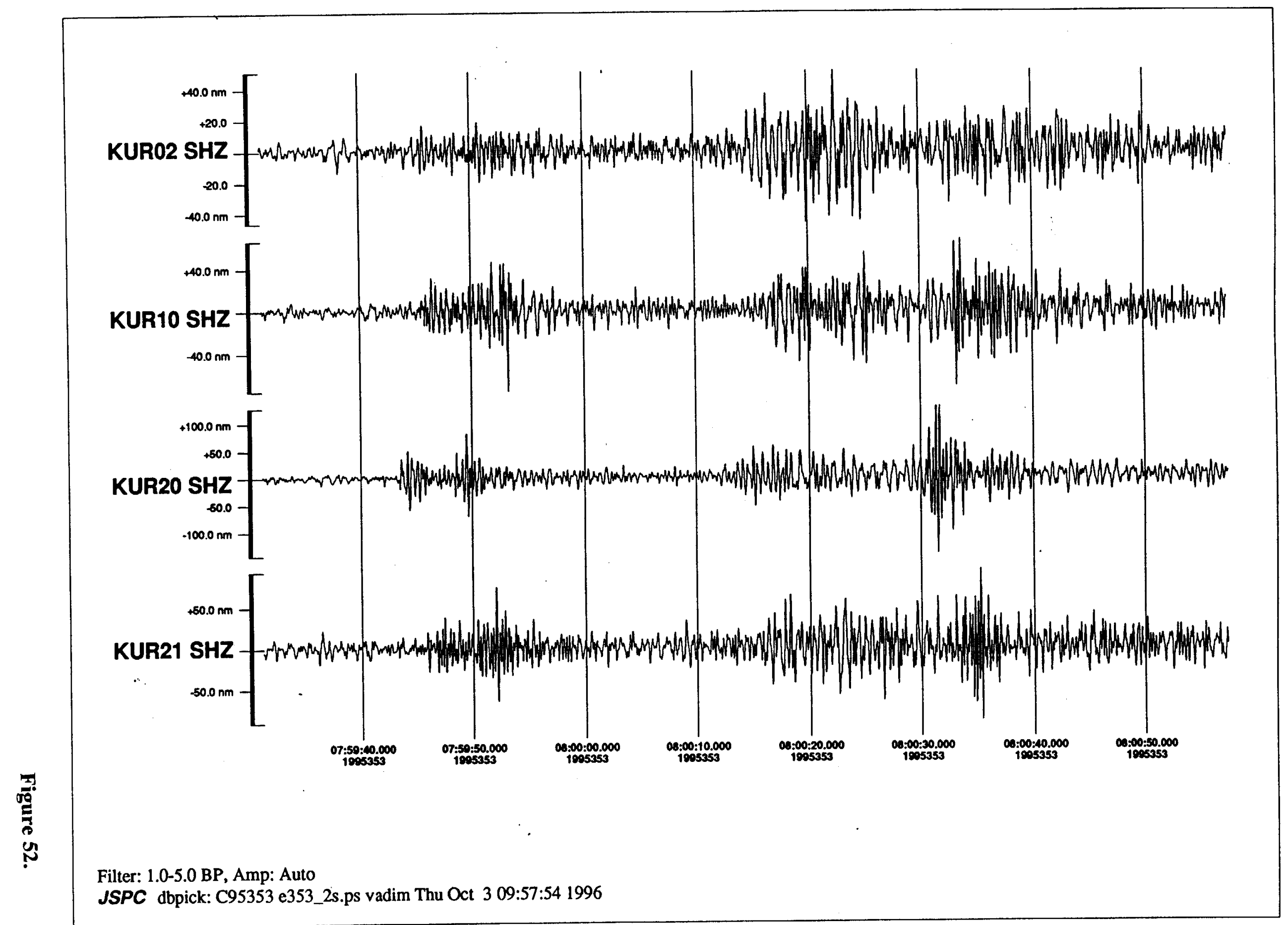




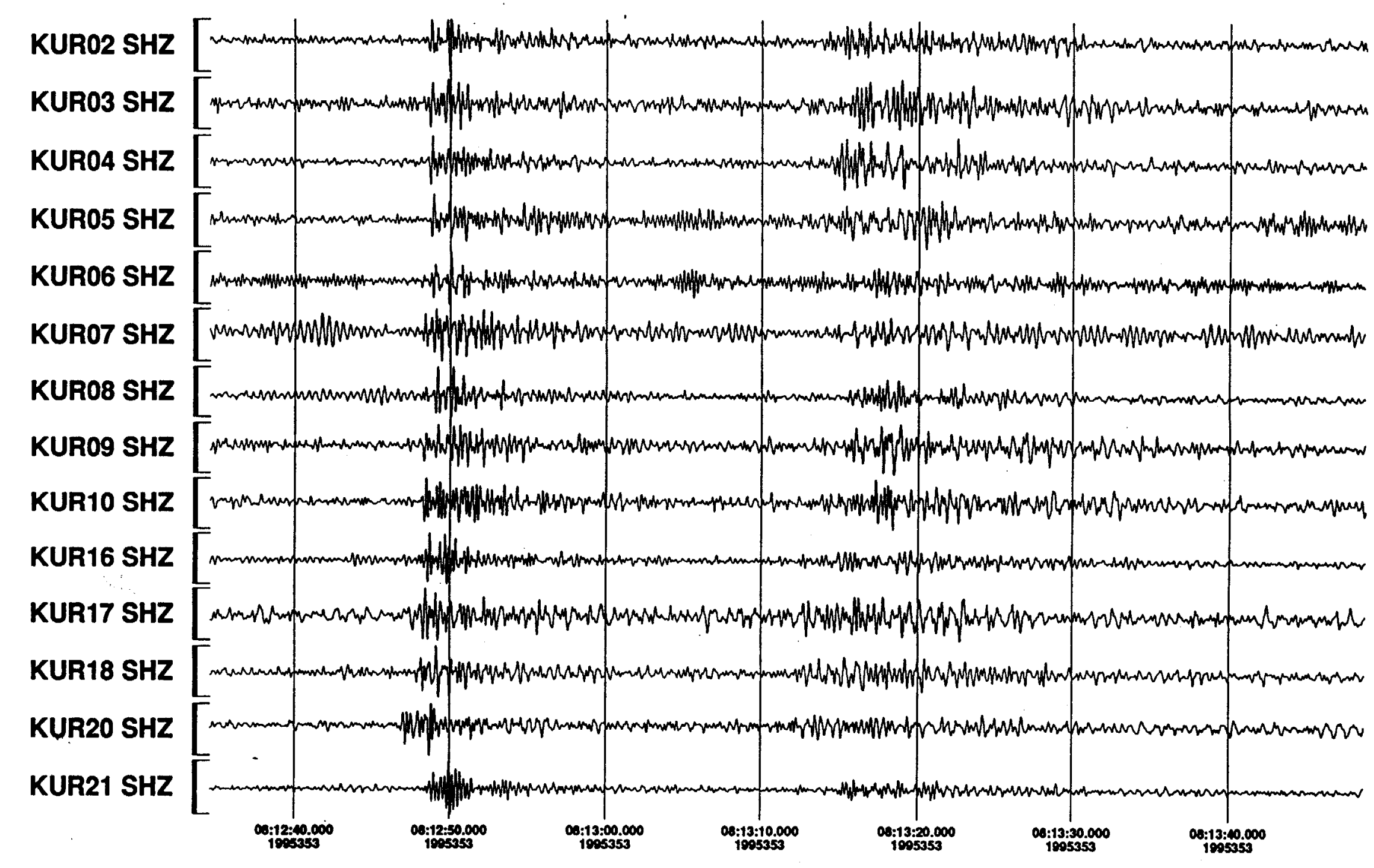


新

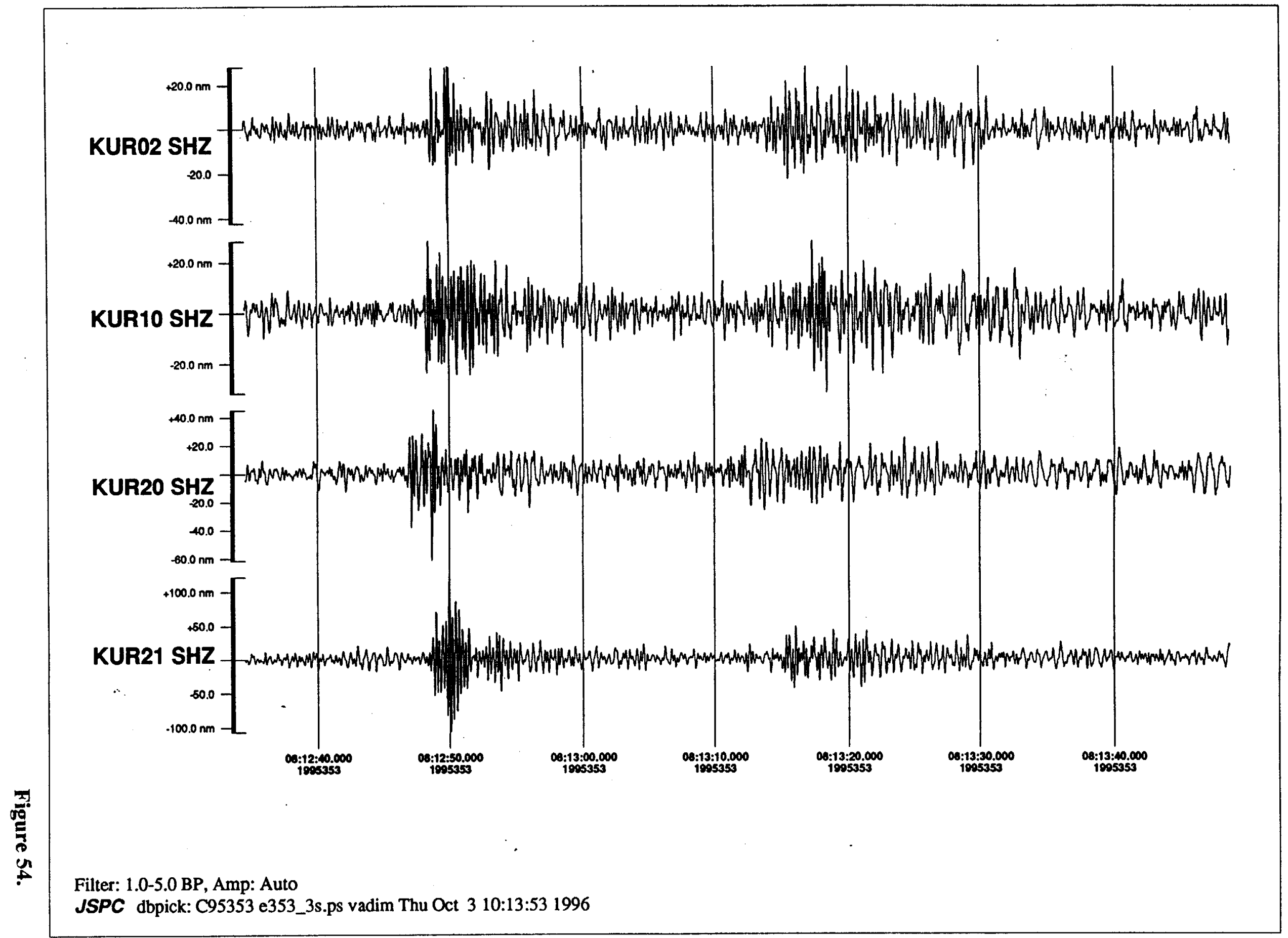




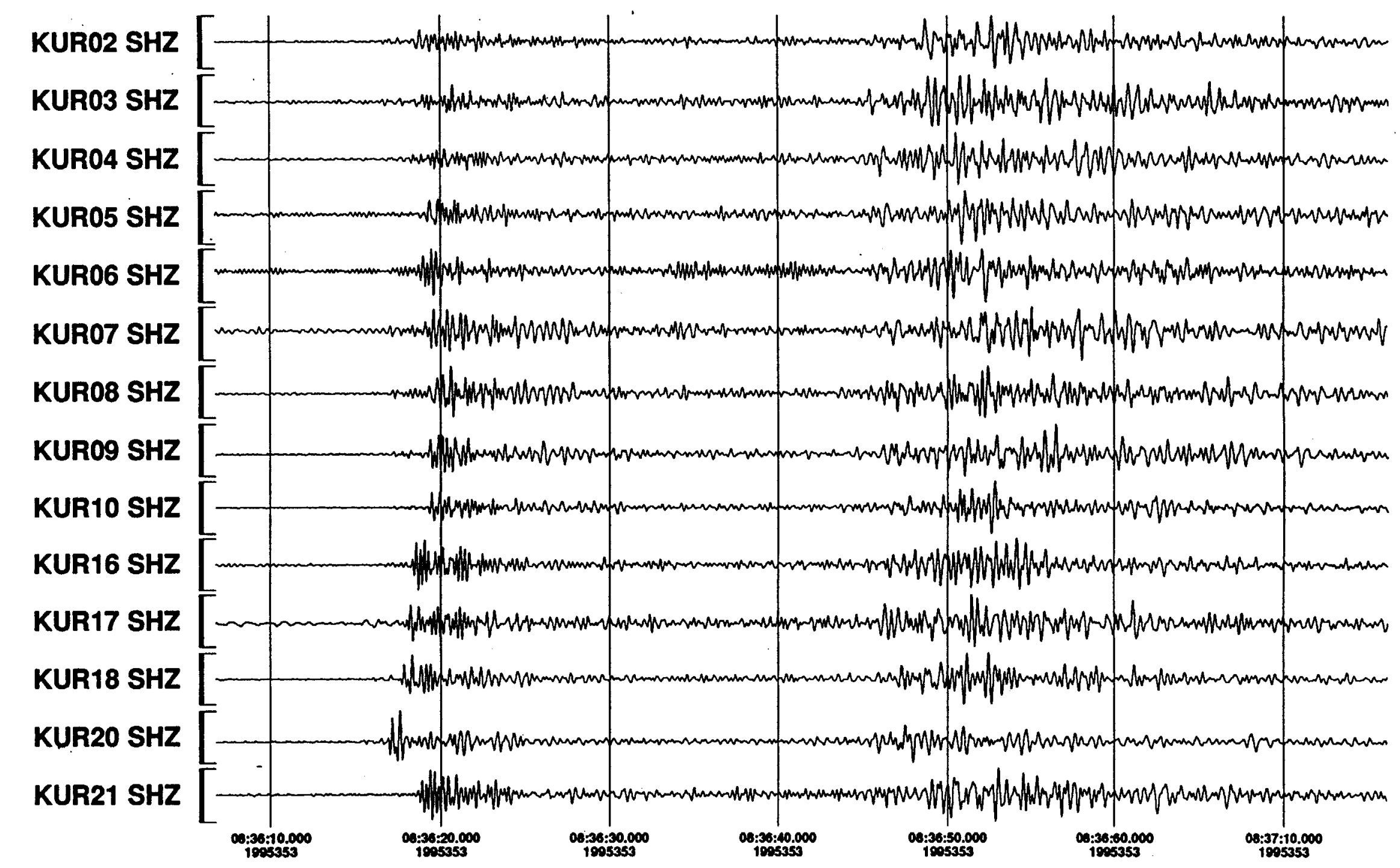

Filter: 1.0-5.0 BP, Amp: Auto

JSPC dbpick: C95353 e353_4.ps vadim Sun Oct 6 01:48:17 1996 


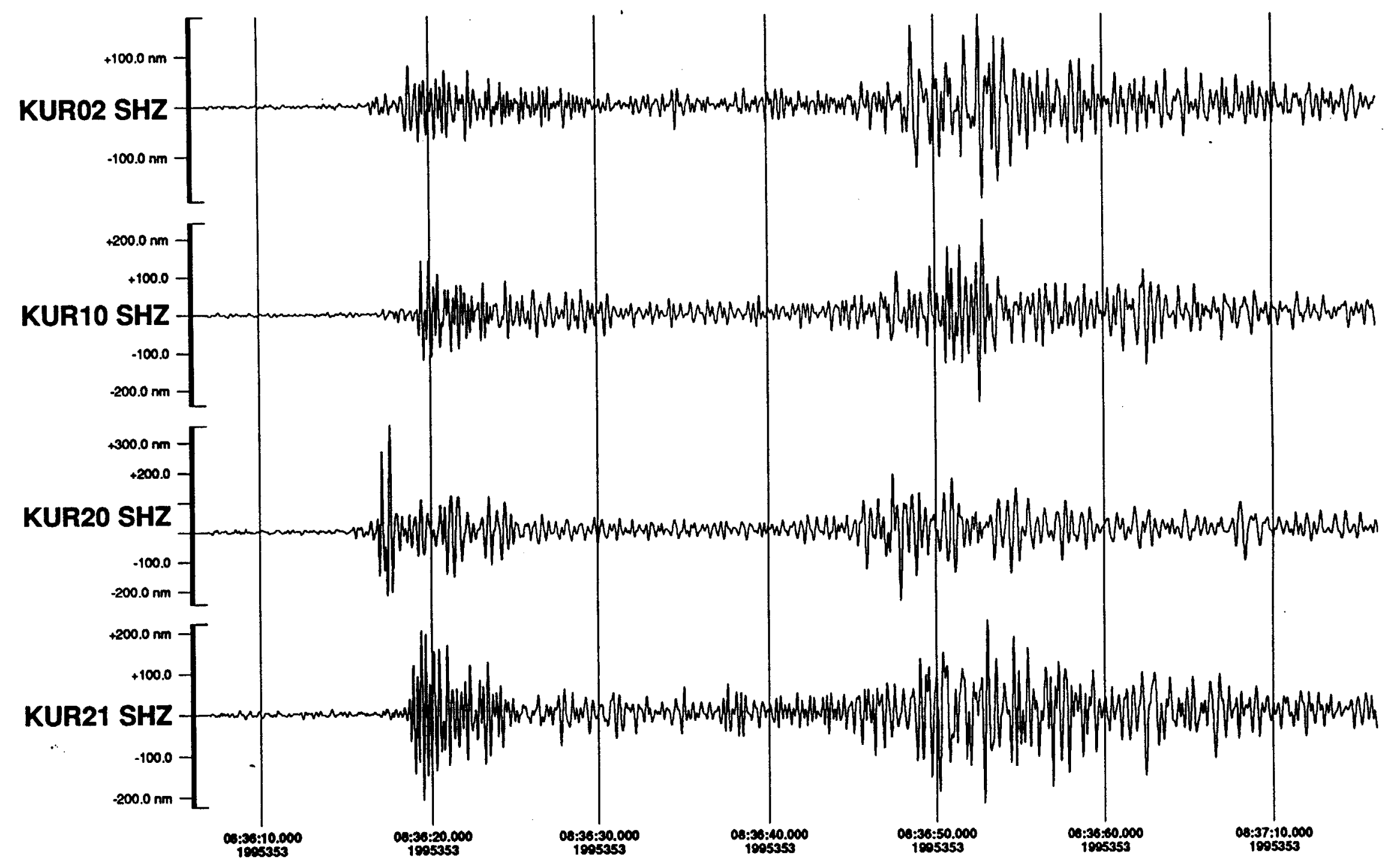




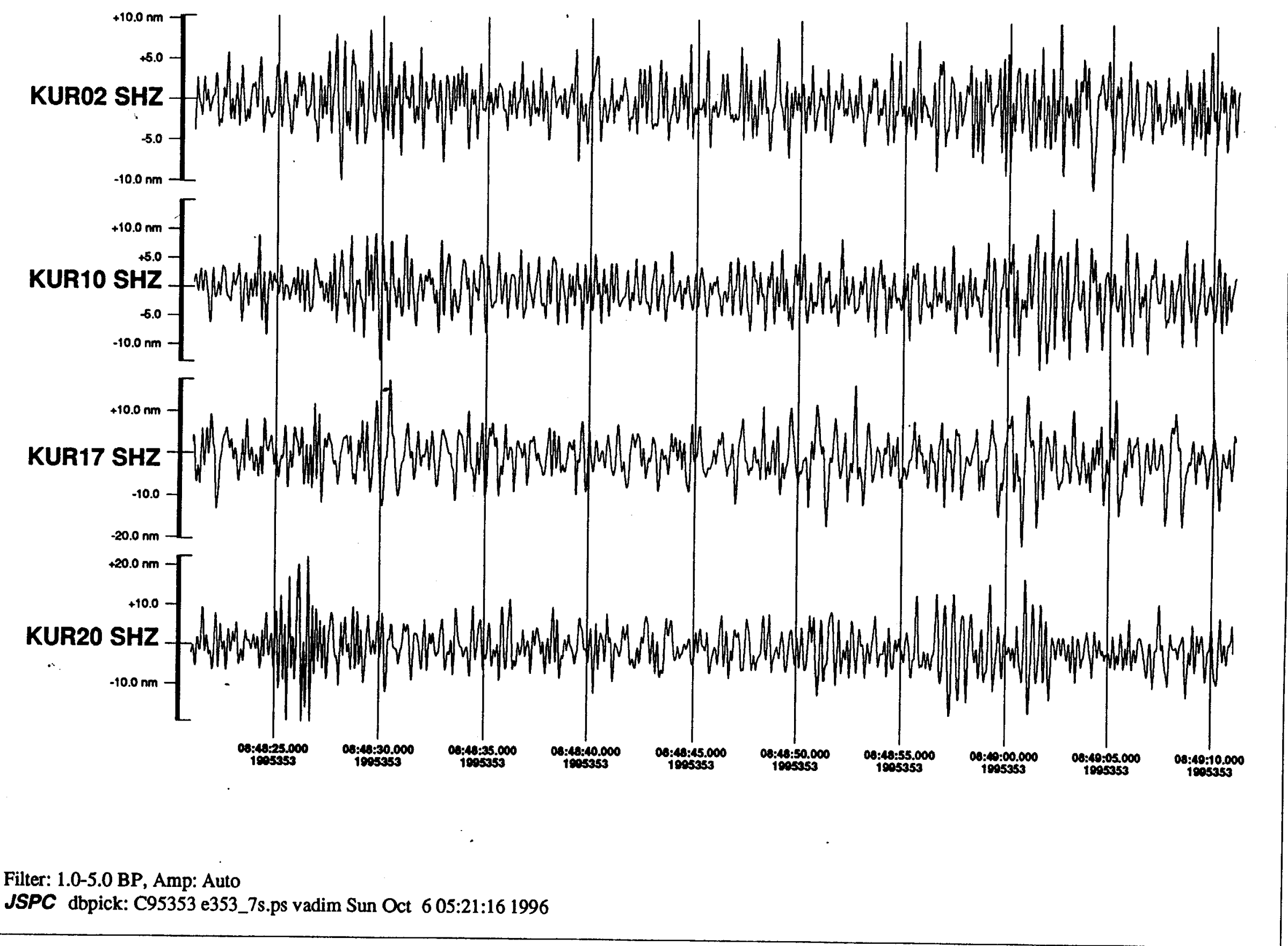




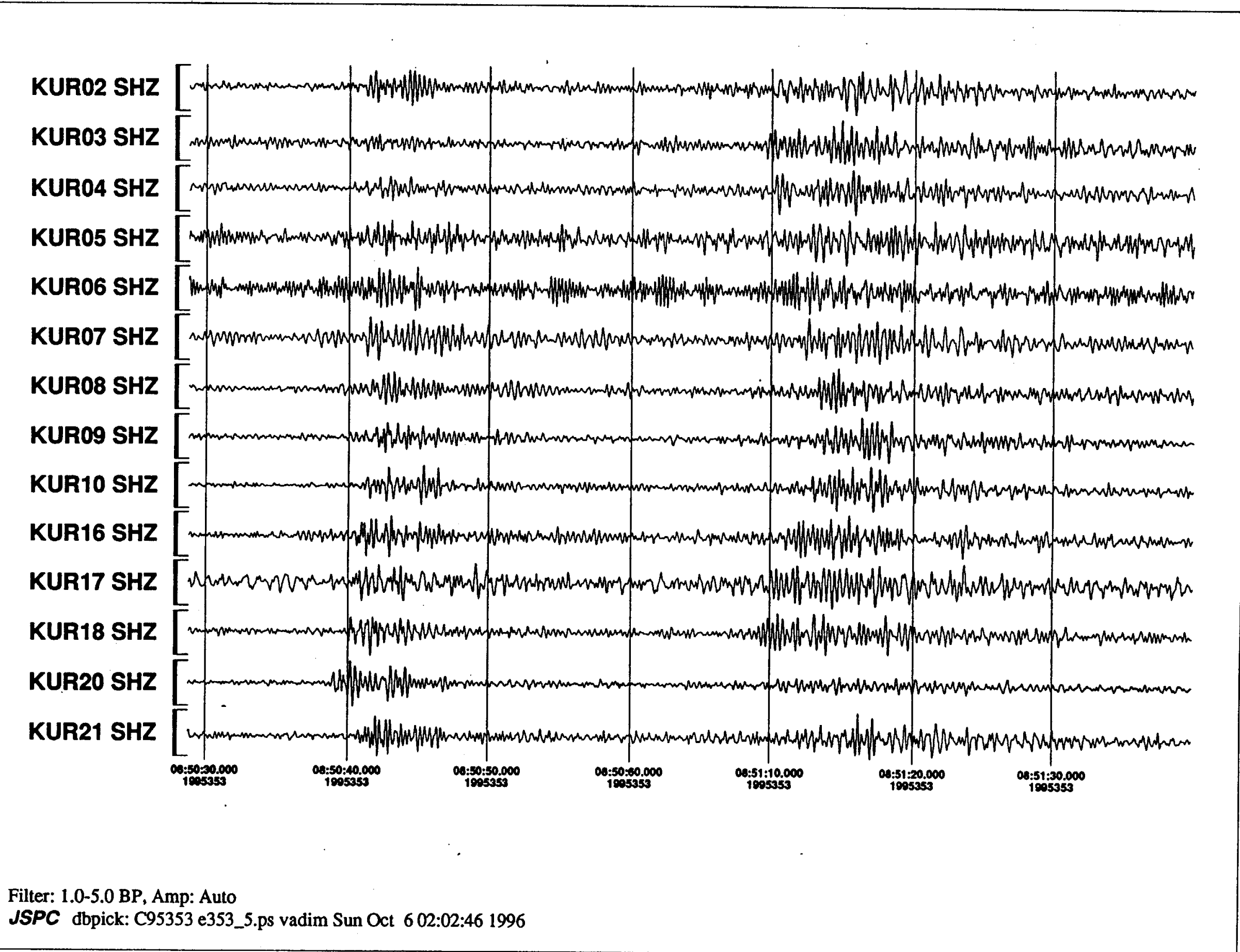




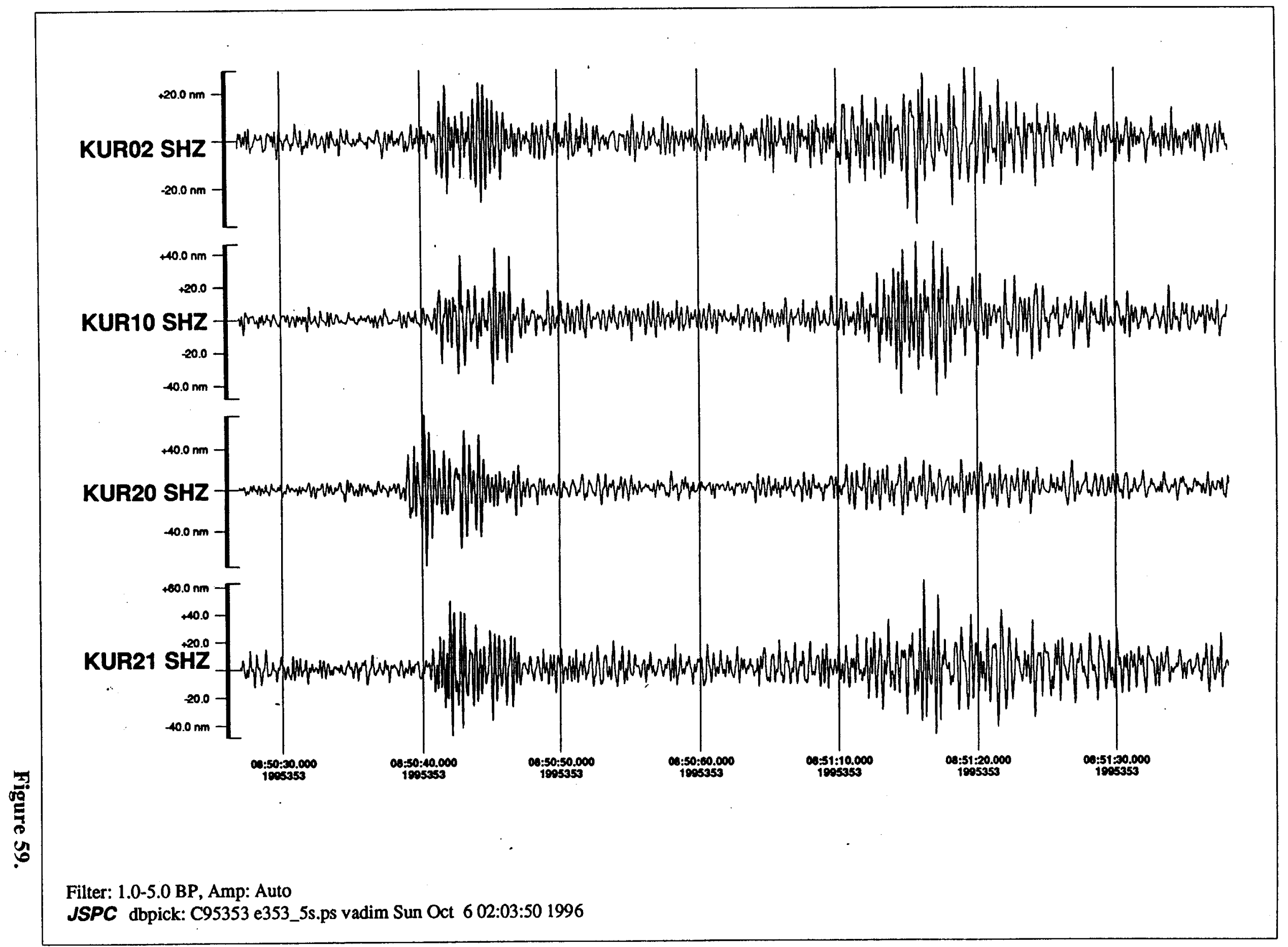




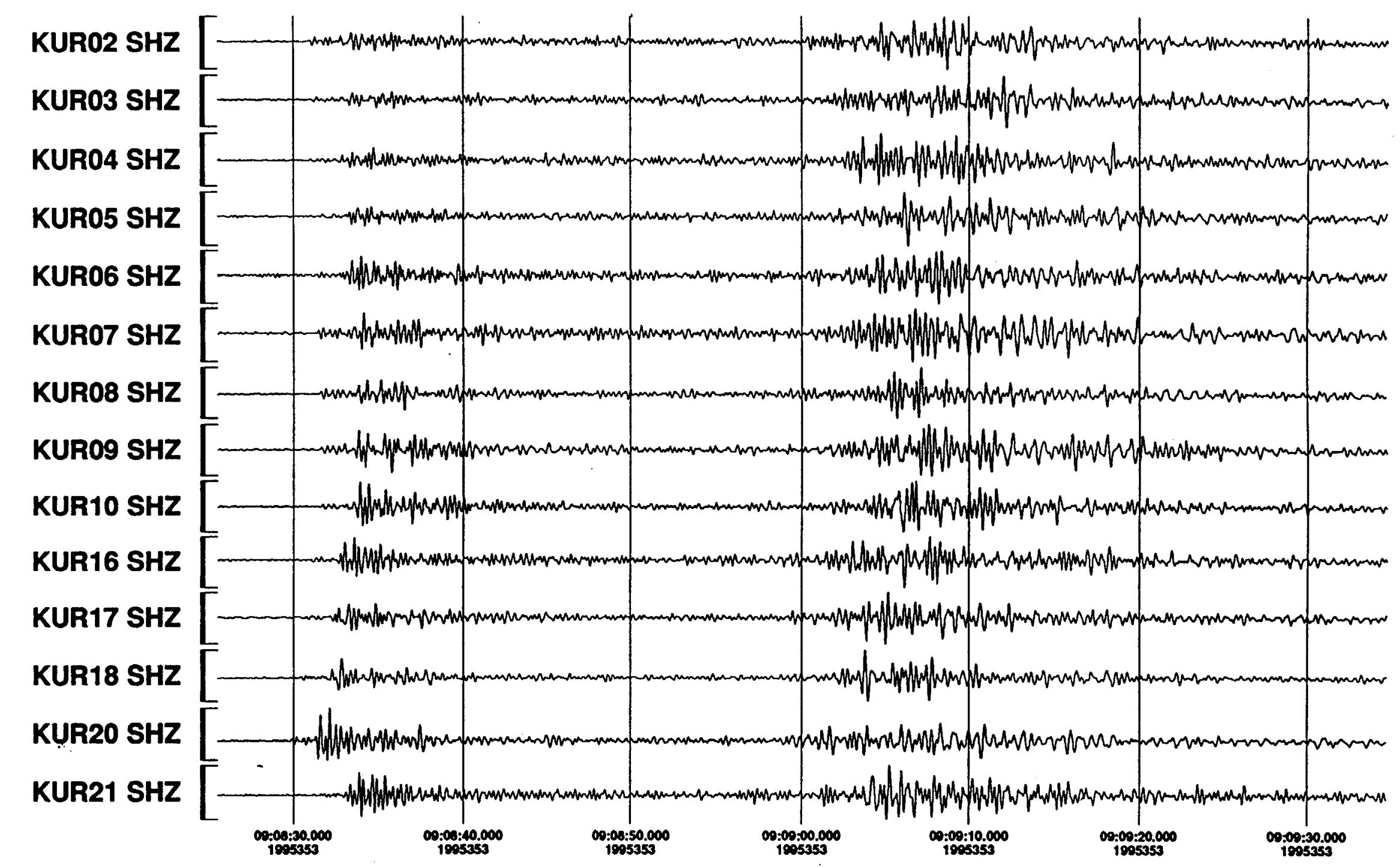

Filter: 1.0-5.0 BP, Amp: Auto

JSPC dbpick: C95353 e353_6.ps vadim Sun Oct 6 05:43:56 1996 


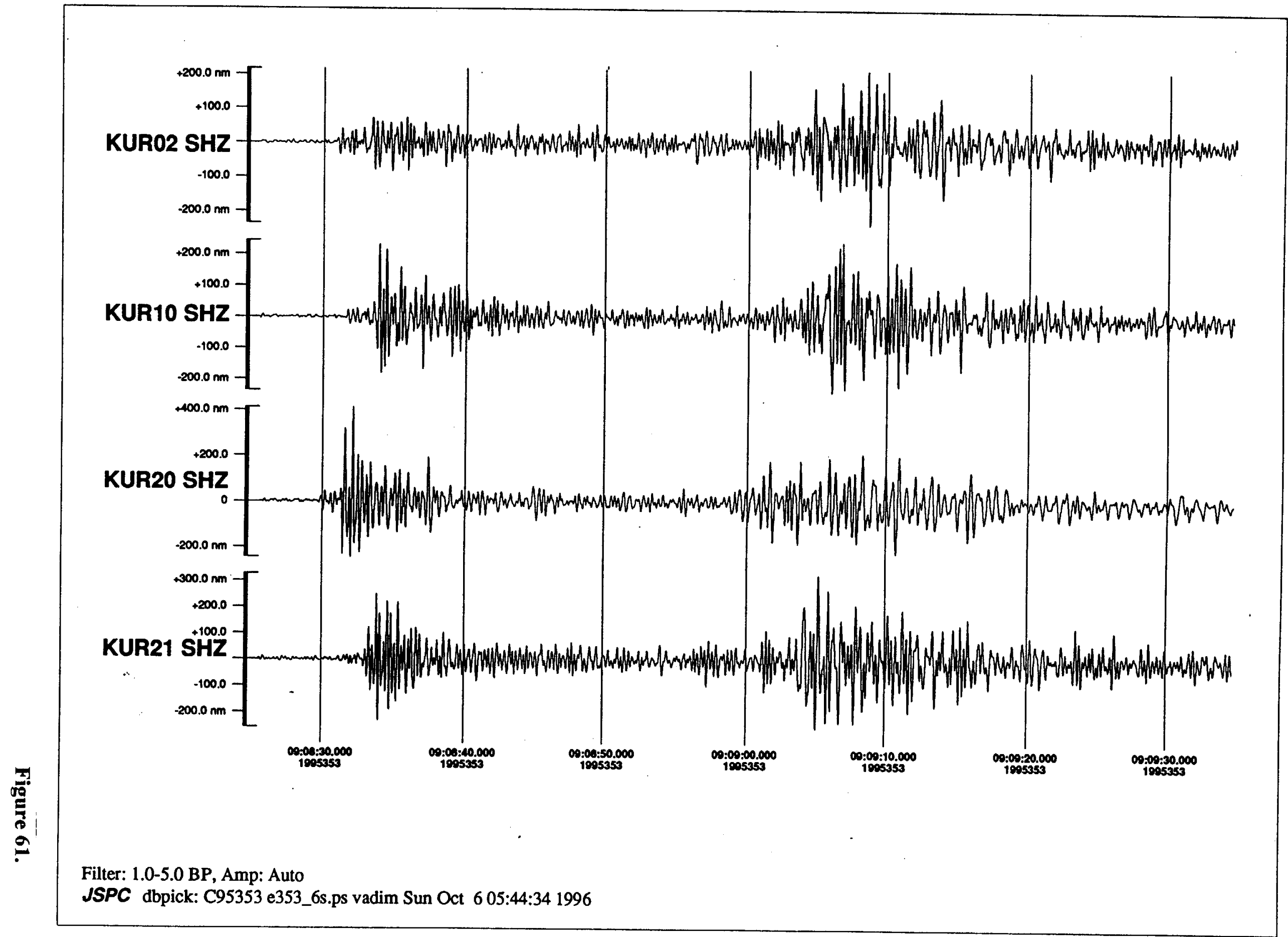




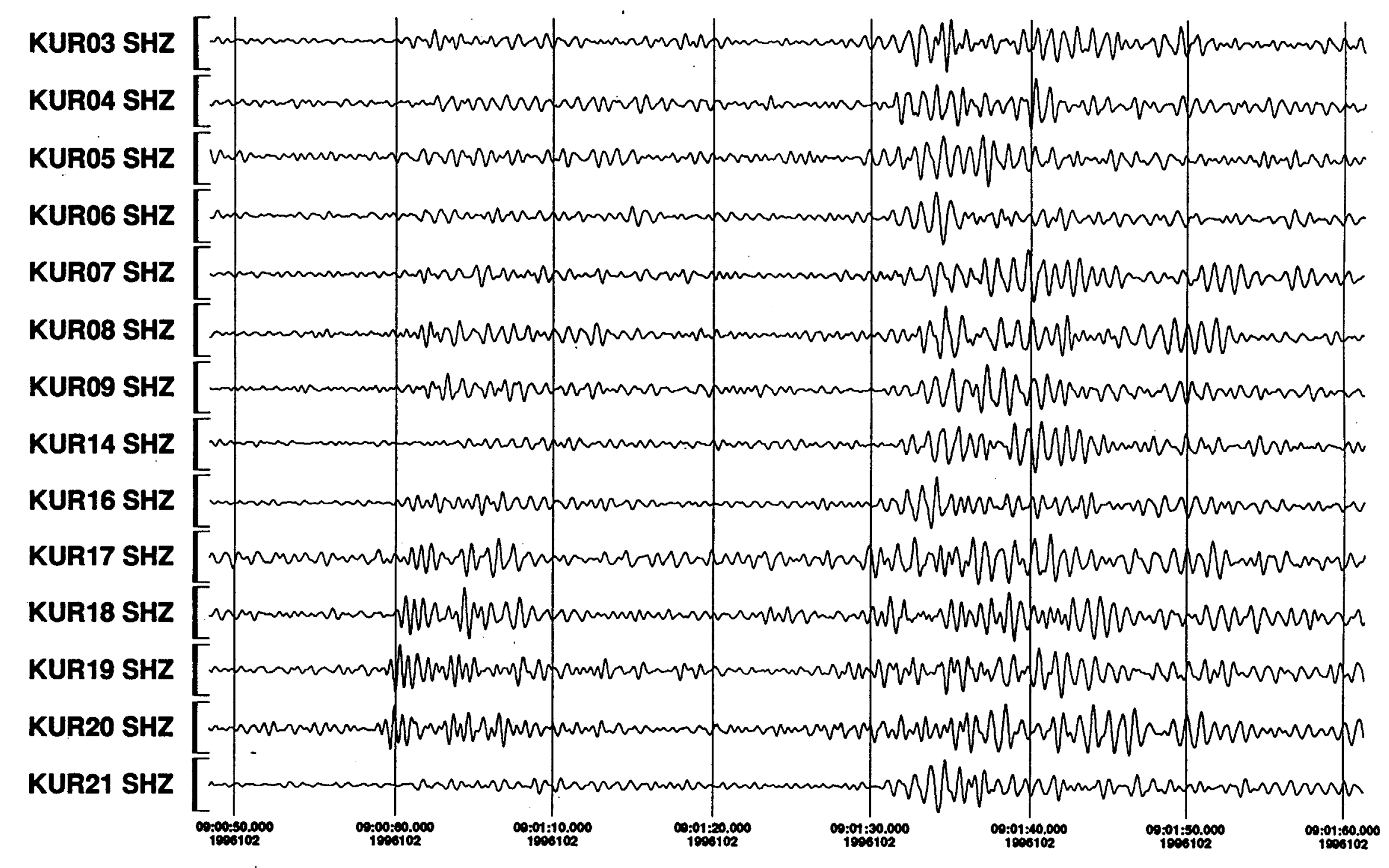


政

\#.

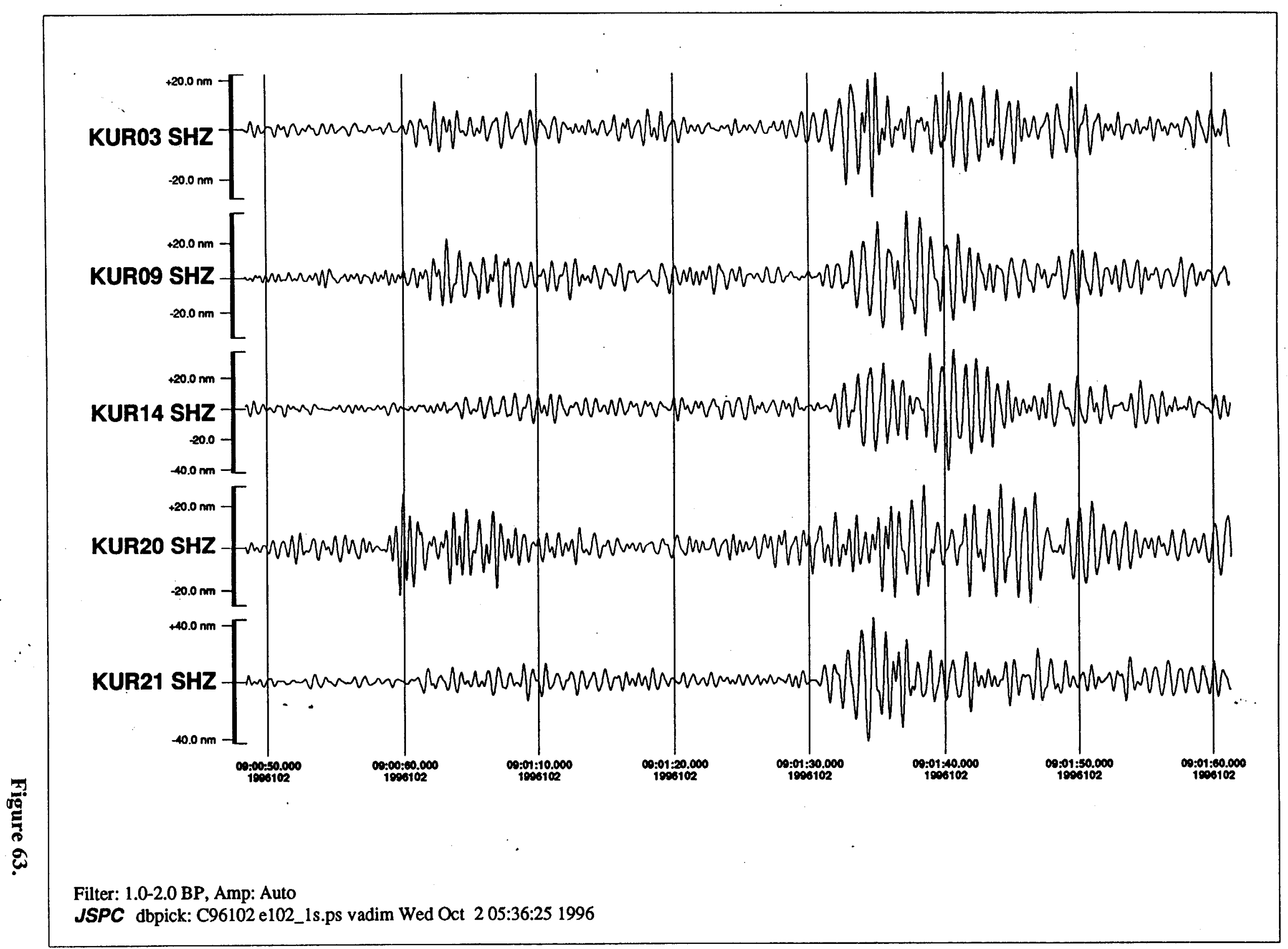




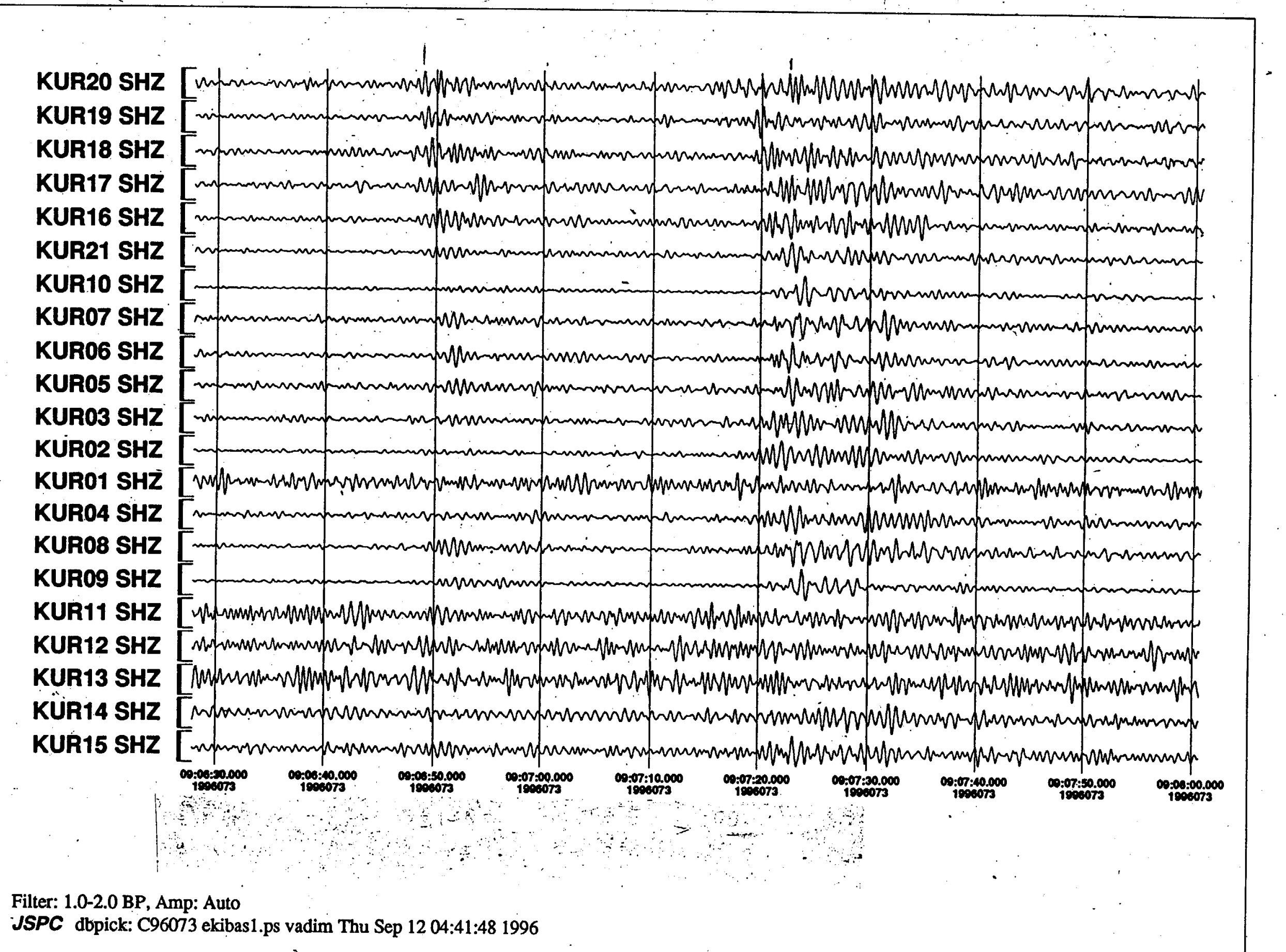




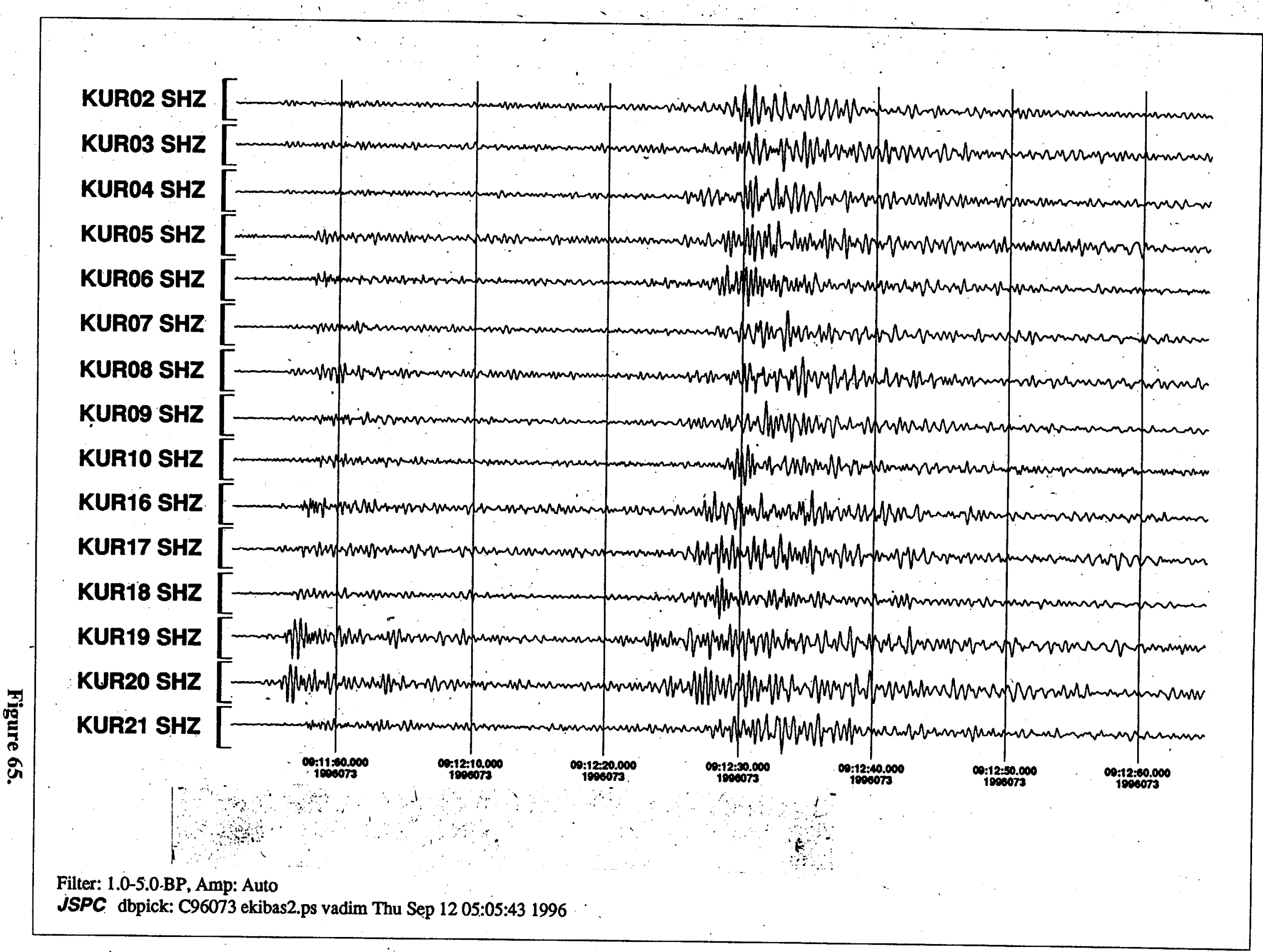




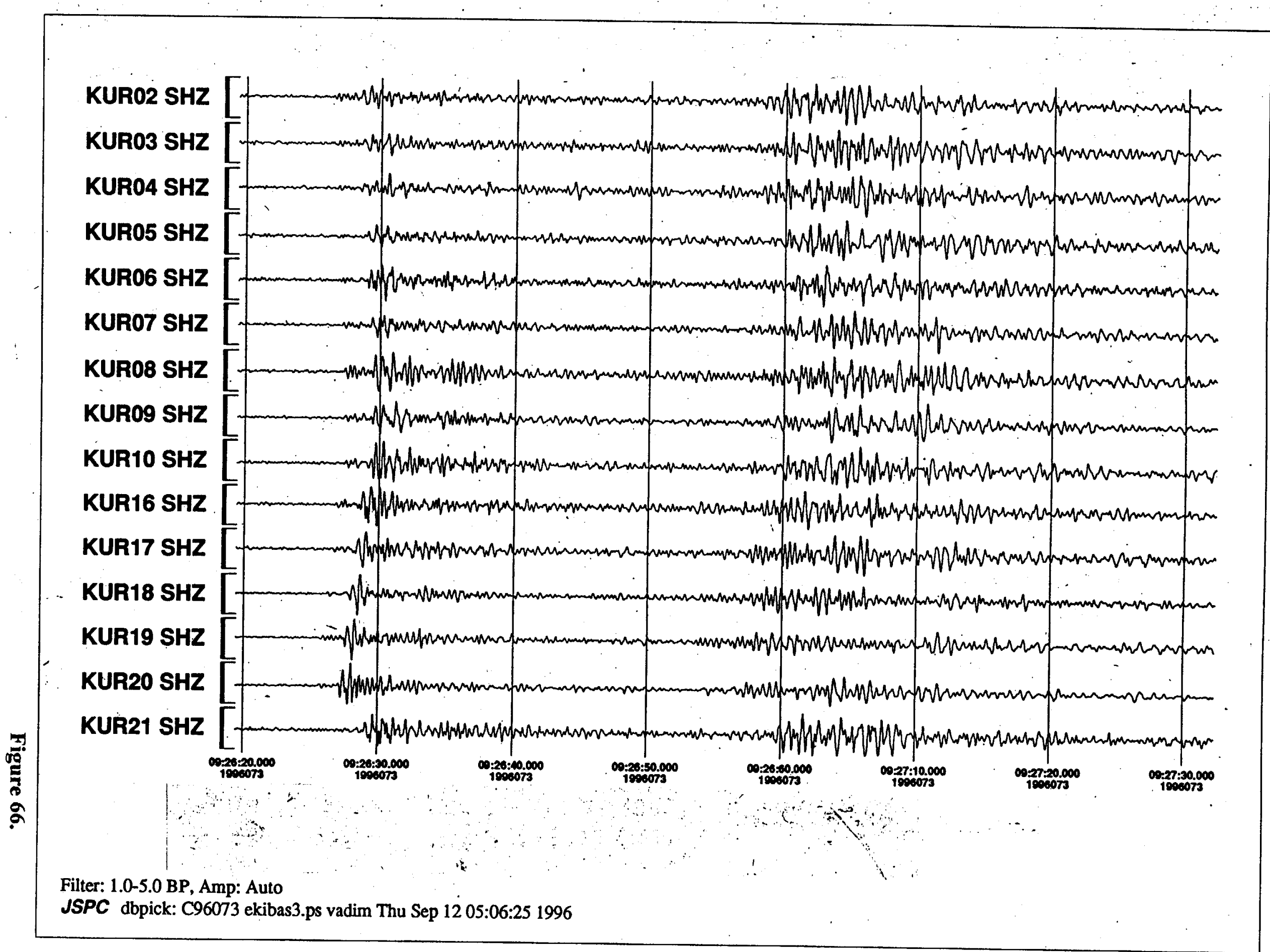




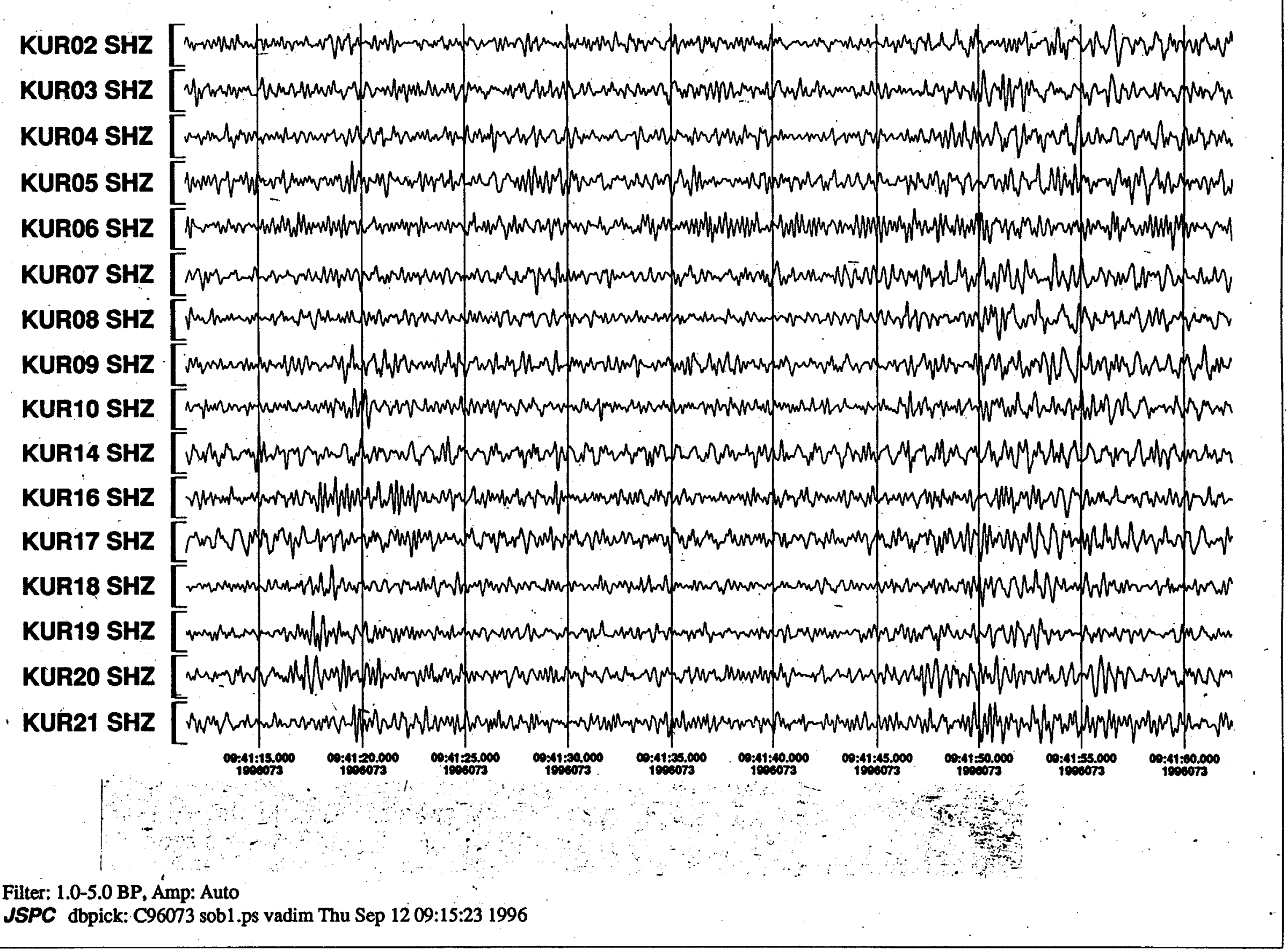




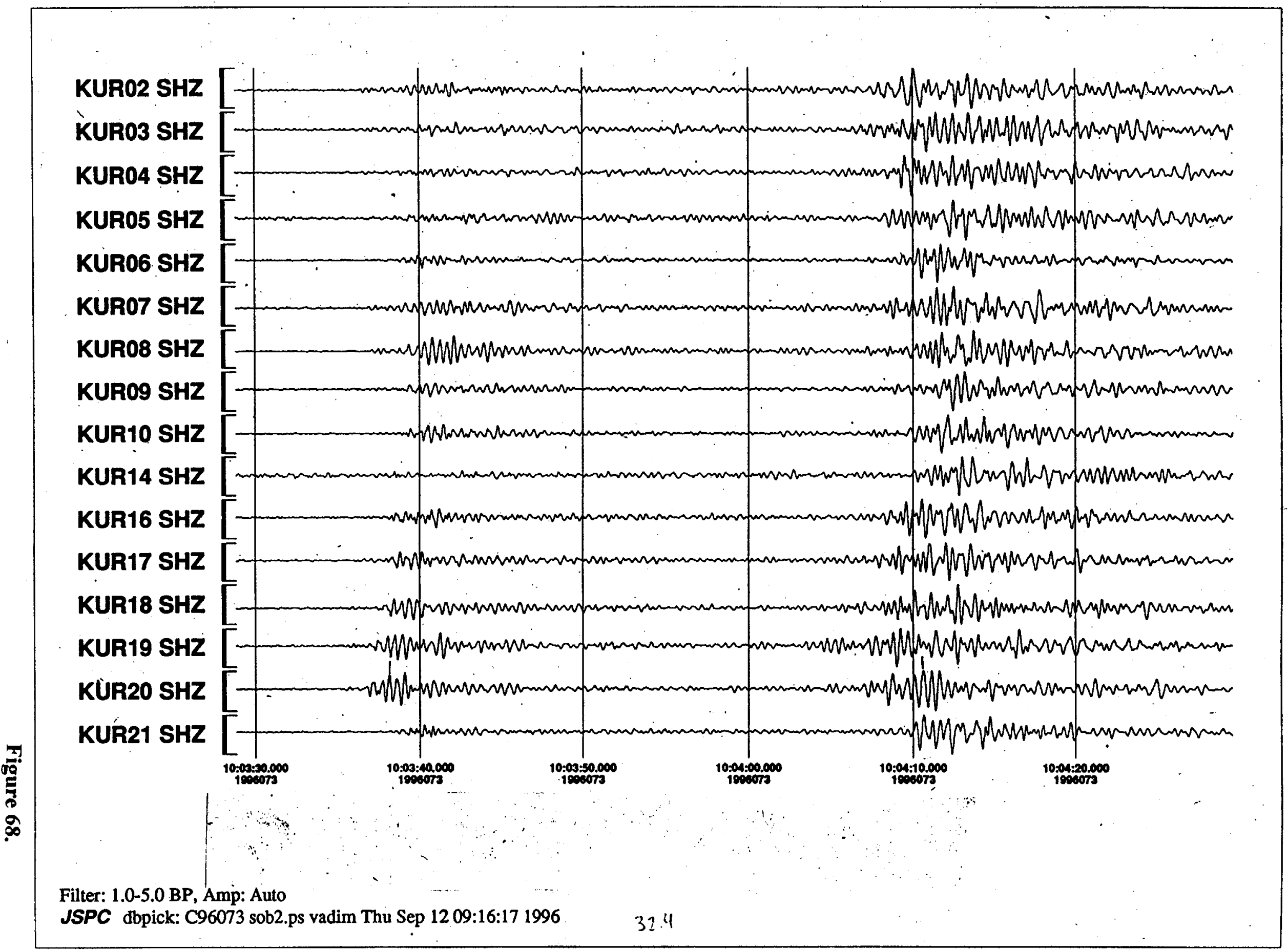




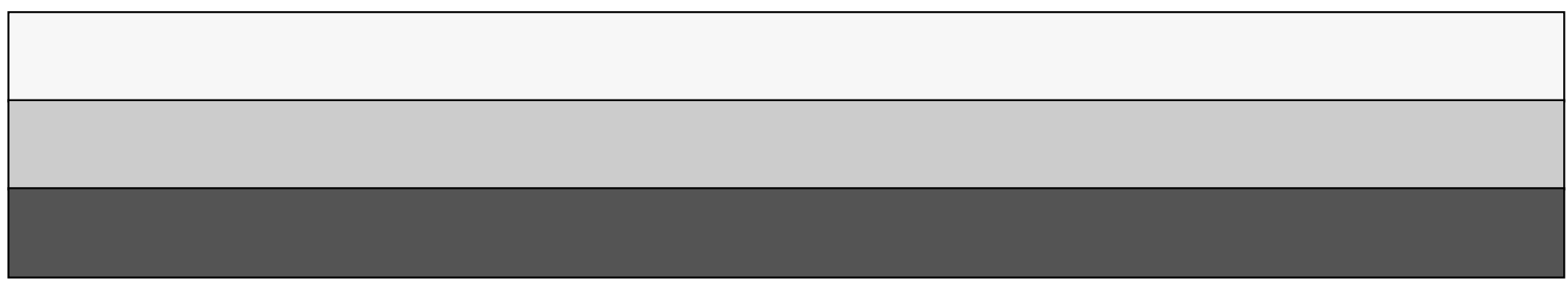

